\title{
Protest Matters: The Effects of Protests on Economic Redistribution*
}

\author{
Belinda Archibong ${ }^{\dagger}$ \\ Barnard College
}

\author{
Tom Moerenhout \\ Columbia University
}

\author{
Evans Osabuohien \\ Covenant University
}

February 7, 2022

\begin{abstract}
Can citizen-led protests lead to meaningful economic redistribution and nudge governments to increase redistributive efforts of fiscal resources? We study the effects of protests on fiscal redistribution using evidence from Nigeria. We digitized twentysix years of public finance data from 1988 to 2016 to examine the effects of protests on intergovernmental transfers. We find that protests increase transfers to protesting regions, but only in areas that are politically aligned with disbursing governments. Protesters also face increased police violence. Non-protest conflicts do not affect transfers and protests do not affect non-transfer revenue. The results show that protests can influence fiscal redistribution.
\end{abstract}

JEL classification: D7, H2, H4, H5, H7, O10, O43, N37

Keywords: Tax, Transfers, Fiscal, Revenue-Sharing, Economic, Protest

*Thanks to the Gates Foundation and the International Centre for Tax and Development (ICTD) for funding this research. Thanks to Ebonya Washington, Akpan Ekpo, Ngozi Okonjo-Iweala, James Fenske, Isaiah Andrews, Steve Nafziger, Agatha Archibong, Leonard Wantchekon, Jim Poterba, Gary Hoover, Sandy Darity, Francis Annan, Bill Spriggs, 2 anonymous referees at ICTD and participants at the Nigerian Tax Research Network and CSEA workshops, and the AEHN, EHDR, CSAE and DITE conferences for useful comments and suggestions. All errors are our own.

${ }^{\dagger}$ Corresponding author. Barnard College, Columbia University. 3009 Broadway, New York, NY 10027, USA. ba2207@columbia.edu. 


\section{Introduction}

"We turn out in the streets and nothing seems to happen. Maybe we're doing it wrong"

- Nathan Heller, The New Yorker, August 14, 2017

In May, 2020, an African-American man named George Floyd was killed after a white police officer knelt on his neck for multiple minutes during a routine arrest ${ }^{1}$. The brutality of the event and others like it directed towards Black citizens, reignited a series of protests against racism and police brutality and for distributive justice under the Black Lives Matter (BLM) movement. Over 15 million people are estimated to have participated in the BLM protests in 2020 alone, and the protests and others like it over the past decade resulted in the 2010s period being labeled the 'the decade of protest' ${ }^{\prime 2}$. Many of the stated aims of these protests have highlighted distributive justice claims, through for example, reparations to descendants of African slaves in the BLM movement, and redistribution of economic capital in the 2011 Occupy Wall Street protests ${ }^{3}$. But can protests lead to meaningful changes in government policy, particularly around the redistribution of economic resources? This is a difficult empirical question to answer partly due to both the complexity of fiscal systems around the world, and the paucity of data on subnational public financing.

We circumvent these empirical difficulties, and address this question using evidence from Nigeria. Nigeria's highly centralized fiscal system makes it an informative region to study how governments might directly deploy fiscal resources as a response to citizen-led protests. While most countries around the world operate some type of revenue sharing

\footnotetext{
${ }^{1}$ Source: https://www.nytimes.com/2020/05/31/us/george-floyd-investigation.html

${ }^{2}$ Source: https://www.nytimes.com/interactive/2020/07/03/us/george-floyd-protests-crowd-size.html; https://www.npr.org/sections/pictureshow/2019/12/31/790256816/the-2010s-a-decade-of-protests-aroundthe-world. Figure A2 shows a snapshot of news headlines around the world.

${ }^{3}$ Source: https://www.reuters.com/article/us-usa-politics-race/slavery-reparations-sought-in-first-blacklives-matter-agenda-idUSKCN10C3E1
} 
scheme where, for example, a federal government entity disburses conditional or unconditional grants to subnational entities, Nigeria is one of more than 30 countries with revenue sharing schemes based on revenues from natural resources ${ }^{4}$. This allows us to more carefully study the effects of protests on the distribution of revenues from a plausibly exogenous source (oil in the Nigerian case) under a heavily consolidated- top-down revenue sharing system where the central government can choose to respond to ostensibly economic grievance driven protests by directly disbursing fiscal resources to assuage contentious regions and quell protests. We construct a new dataset from 26 years of archival records on public finance from 1988 to 2016, assembling data on revenues and expenditures, along with geocoded information on protests to test our hypotheses in Nigeria. The breadth of data over these years and the richness of Nigeria's political history also allow us to test hypotheses from the electoral politics literature on differential responses of central governments to protests under autocratic versus democratic regimes ${ }^{5}$ (Ellman and Wantchekon, 2000; Hollyer, Rosendorff, and Vreeland, 2015).

The aim of this paper is to investigate the effects of protests on fiscal redistribution and examine how governments respond to protests when they can directly control the distribution of fiscal resources. We do this in four steps. First, to fix ideas about the links between protests and intergovernmental transfers, we outline a simple principal-agent conceptual framework in which the principal is the federal government leader with full control of disbursement over centrally collected revenues and the agent is a state government leader dependent on the principal for revenue transfers. The objective of the principal is to quell protests that may be destabilizing to their tenure in office. This requires some level of cooperation or effort from state government leaders to quell protests. Assume agents cannot be perfectly monitored and the principal must motivate them by sharing some portion of revenues with

\footnotetext{
${ }^{4}$ As shown in Figure A1 in the Appendix (Oates, 1999).

${ }^{5}$ Nigeria has a military government for most of the period from 1970 to 1999, and a democratic government post 1999 .
} 
them. Then, given simple assumptions around the cost of agent effort, one prediction of the framework is that the principal may transfer more or less revenues to agents in protesting regions depending on the perceived cost of agent effort in quelling protests. When the agent's optimal effort is non-negative, as may be the case with agents that share political preferences or are politically aligned with the principal and hence have an incentive to keep the principal in office, the principal may transfer a greater share of revenues to the agent. When the perceived agent effort is negative, as may be the case for non-aligned agents, the principal reduces transfers to the agent.

In step two, we test the predictions from the framework and examine the associations between protests and transfers. We define protests as protest intensity in a particular district or state and measure it in two ways. The first measure is our main measure and is the statelevel deviation of the numbers of protest events in each state from the national average numbers of protest events in each year or the state-level z-scores relative to the national mean within a particular year. The specification captures the relative intensity of protests within a state, and the sensitivity of federal government responses to marginal deviations in a state's level of protests from the national average. The second measure defines protest intensity at the state level as strictly positive deviations from the national mean, or as an indicator that equals one if the state's protest z-score is greater than zero. This measure provides an extensive margin estimate that captures the federal government response to relatively high versus low levels of protests within states. We show that higher levels of protests in a state are associated with both increases and decreases in revenue transfers from federal governments to protesting states over the military and democratic periods. Over the military period, protests increase one transfer outcome, called VAT transfers, by between $5.2 \%$ and $11.5 \%$, and increase a separate transfer outcome, called allocation transfers, by 6.8\%. Over the democratic period, protests decrease allocation transfers by between $0.5 \%$ and $0.7 \%$. 
We explore political alignment, or whether the federal government leader or president and the state government leader or governor come from the same political party, as a channel that may explain the heterogeneity in the effects of protests on transfers following our conceptual framework. While there is no variation in alignment in the military period, due to all military state governors being direct political appointees and hence, by our definition, politically aligned with the president, we can examine results by alignment in the democratic period with the introduction of electoral politics. We find that protests increase VAT transfers in aligned areas by between $4 \%$ and $6.6 \%$, but decrease VAT transfers by around $1 \%$ in non-aligned areas. The results on decreased allocation transfers in protesting states are almost entirely driven by protests in non-aligned states. We conduct a number of falsification tests on our results and show that there is no significant association between other conflict events and transfers. We also show that there is no association between protests and non-transfer revenue like internally generated revenue (IGR).

In the third step, after presenting the correlations between protests and intergovernmental transfers, we address concerns of reverse causality and omitted variable bias using an instrumental variables (IV) strategy. Guided by the growing social science literature on the causes of protests that has highlighted the costs of coordination and the role of economic downturns as being important joint drivers of protests (Enikolopov, Makarin, and Petrova, 2020; Manacorda and Tesei, 2020; Battaglini, 2017; Madestam et al., 2013), we construct an instrument for our protest measure that is based on two parts. The instrument is the interaction of (1) the level of ethnolinguistic similarity in a state and (2) the share of states experiencing a negative economic shock within the year. We explain the logic of the instrument in further detail in the text and note here that the first component of the instrument addresses the cost of coordination for protest by capturing the fact that language may be a significant barrier to collective action for protest, inasmuch as it represents a barrier to easy communication. Regions with more people from ethnicities that speak the same language 
may have an easier time communicating to organize for protests. The second component of the instrument addresses the role of economic downturns in spurring protests by using the share of states that have experienced a drought or flood, which would be a significant source of economic hardship for people in a region where a major portion of the local population works in agriculture, and the vast majority of agriculture is rain fed.

With the IV specification, we find similar results to the OLS estimates, that protests affect fiscal redistribution, decreasing allocation transfers and slightly increasing VAT transfers in line with the OLS results. Given concerns that the instrument may directly affect intergovernmental transfers or that it may affect transfers through a channel other than protests, we also present a number of falsification tests for the instrument. We show that the instrument more strongly predict protests in states that have achieved some threshold level of mobile phone penetration, where same language speaking residents can benefit from communication network externalities to more easily organize protests during economic downturns. We also show that our interacted ethnolinguistic similarity instrument positively predicts protests but not intergroup armed conflict like battles, following previous evidence that people from similar groups are more likely to cooperate and less likely to fight with each other (Montalvo and Reynal-Querol, 2005).

Finally, in step four, given that responses to protests by governments are not only fiscal and can include increased violence against protesters, we examine the effects of protests on policing. We find suggestive evidence that protests increase policing and police violence against protesters, particularly in states that are not politically aligned with disbursing federal governments. In contrast, protests are associated with decreased police violence against protesters in aligned states. We also examine the association between protests and state expenditure and document significant negative associations between protests and recurrent expenditure, providing suggestive evidence for the grievance based claims of, in particular, 
public sector workers around non-payment of salaries in protesting states. The results provide strong evidence that protests can influence fiscal redistribution. The ways in which they do this depends on the political relationships within governments and between disbursing federal governments and protesting regions. Governments can also respond to protests with increased state violence against protesters.

We add to two distinct literatures. First, we add to the literature on the political economy of protest (Cantoni et al., 2019; El-Mallakh, 2020; Madestam et al., 2013; Acemoglu, Hassan, and Tahoun, 2018; Mazumder, 2018). Previous work has highlighted the role of social media in lowering collective action costs and mobilizing protests (Enikolopov, Makarin, and Petrova, 2020; Manacorda and Tesei, 2020; Battaglini, 2017) and examined the effects of protests on voting behavior and electoral competition (Madestam et al., 2013; El-Mallakh, 2020; Ellman and Wantchekon, 2000), stock market valuations (Acemoglu, Hassan, and Tahoun, 2018), women's labor market outcomes (El-Mallakh, Maurel, and Speciale, 2018), and political attitudes (Mazumder, 2018), but there is almost no research on the effects of protests on economic redistribution. Most of the work on the effects of protests on economic outcomes more generally, have focused on the economic costs of protests, with evidence showing that protests decrease stock market valuations of politically connected firms (Acemoglu, Hassan, and Tahoun, 2018) and decrease property values (Collins and Margo, 2007). Given that a major stated driver of citizen participation in protests are demands for economic redistribution, whether these protests can nudge governments to engage in more fiscal redistribution is an important, but as yet largely unaddressed part of the literature. Our study is the first, to our knowledge, to provide quantitative estimates of the effects of citizen-led protests on fiscal redistribution by governments.

We also contribute to the economics literature on fiscal federalism and fiscal decentralization and a related literature on regional favoritism in the distribution of fiscal resources 
(Oates, 1999, 1993; Musgrave, 1997; Poterba, 1994; Buchanan, 1950; Zhuravskaya, 2000; Boadway and Shah, 2007; Hodler and Raschky, 2014). While this work has mostly focused on explaining the incentive structure of revenue sharing schemes under democratic regimes separately from authoritarian contexts, we show that the incentive constraints of government entities in revenue sharing environments can remain stable under both democratic and nonelectoral regimes. The social science literature on regional favoritism has highlighted the role of politician origin in economic outcomes, (Hodler and Raschky, 2014; Fiva and Halse, 2016), the role of political party alignment in economic outcomes (Cullen, Turner, and Washington, 2019), and the distortions in incentives of political stakeholders that can arise as a result of regional and party favoritism (Zantman, 2002; Zhuravskaya, 2000; Casey, 2015). We add to this literature and show that political alignment matters for the disbursement behavior of central governments in response to protests. We also provide suggestive evidence that alignment can affect governments' use of violence in response to protests.

The paper is organized as follows: Section 2 provides historical background on intergovernmental transfers and protests in Nigeria. Section 3 outlines a simple conceptual framework. Section 4 describes the data on public finance and protests. Section 5 reports quantitative estimates of the effects of protests on intergovernmental transfers. Section 6 examines policing and state expenditure outcomes. Section 7 concludes.

\section{Fiscal Redistribution and Protests in Nigeria}

\subsection{Intergovernmental Transfers Under Military and Democratic Rule}

Nigeria is a federation comprised of a democratically elected federal government and 37 administrative 'states', consisting of 36 official states, as designated by the 1999 constitution, and a Federal Capital Territory (FCT) at Abuja (Archibong, 2019). The states can be further subdivided into 774 local government areas (LGAs), the smallest administrative unit in the 
country, and 6 geopolitical zones, with geographies correlating strongly with ethnicity in Nigeria as shown in Figure A3 in Appendix A.16. Following Nigeria's discovery of oil in 1956, independence from British colony status in 1960 and a civil war from 1967 to 1970, partly over control over oil resources, the country has operated under fiscal federalism, where the distribution of government revenue, $80 \%$ of which comes from oil receipts, are distributed centrally from the federal government to subnational entities- states and LGAs (Archibong, 2019; Maystadt and Salihu, 2019).

The country experienced almost three decades of military rule from 1970 to $1999^{7}$, followed by democratic governance after 1999. Under both regimes, revenue disbursement was and continues to be extremely centralized. Apart from a constitutional requirement that $13 \%$ of gross oil revenue be shared among oil producing states in proportion to their production volumes, all revenues are remitted to the federal government (Maystadt and Salihu, 2019). The remaining revenue is paid into a Federation Account. Included in the Federation Account are revenues from oil, corporate income taxes, custom and excise duties and, notably, VAT revenue from state governments under Nigeria's highly centralized fiscal system (Alm and Boex, 2008). Given the significant share of revenues from oil in the Account, the gross amount in the Account fluctuates closely with plausibly exogenous changes in the export price of oil (Maystadt and Salihu, 2019). Revenues are then shared by the federal government among the three levels of government according to a vertical and horizontal formula.

The vertical formula has changed over the years, ranging from $48.5 \%$ to $55 \%$ for the federal government, $24 \%$ to $30.5 \%$ for states and $10 \%$ to $20.6 \%$ for LGAs between 1981 and

\footnotetext{
${ }^{6}$ Of the 6 political zones, encompassing the states and LGAs, broadly, the North-West is dominated by the Hausa and Fulani ethnic groups, the North-East is largely populated by the Kanuri ethnic group, the South-West is dominated by the Yoruba ethnic group, and the South-East is dominated by the Igbo ethnic group. The Ijaw/Edo/Bini/Ibibio weakly dominate the SouthSouth zone while the North-Central is home to the Tiv, Nupe and other smaller ethnic populations (Archibong, 2019).

${ }^{7}$ There were brief periods of civilian rule between 1979 and 1983, and for a few months in 1993.
} 
2016 (Okauru, 2012; Onuigbo and Innocent, 2015). There is also a horizontal allocation formula that determines how much of this disbursed revenue should go to each state and local government. The horizontal allocation formula has also fluctuated over the years and weighted five main factors between 1981 and 2016 as follows: (1) equality of states, where each state should get an equal share (40\% to 50\%); (2) population (30\% to $50 \%$ ); (3) internal revenue generation efforts of each state (0\% to 10\%); (4) landmass and terrain (0\% and 10\%) and (5) social development factors like school enrollment, health and water (0\% and 15\%). Transfers to states consist of transfers from the Federation Account known as Allocations and VAT transfers remitted back to states. The VAT transfers partly follow the general horizontal allocation formula, with around $50 \%$ of transfers to states shared equally, $30 \%$ in proportion to population and $20 \%$ based on the individual state's relative contribution to VAT revenues (Maystadt and Salihu, 2019).

State and local governments, including oil producing states, have no control over the rate of federal allocations. The only tax revenue they directly raise and control are internally generated revenues (IGR) largely from personal income taxes and business registration and land leasing fees (Ekpo, 1994; Maystadt and Salihu, 2019; Salami, 2011). States are heavily dependent on federal transfers for revenue; between 1988 and 2016, 65\% of state revenues came from Allocations or allocation transfers, $15 \%$ of state revenues came from VAT transfers, with total transfers from the federal government comprising $80 \%$ of state revenues on average. In contrast, IGR has remained relatively small at only $20 \%$ of state revenues, on average, over the military and democratic periods ${ }^{8}$.

The determination of the formulas and their distribution are very opaque processes in Nigeria. Since the 1980s, the Account has been administered by a federally appointed committee, currently known as the Federation Account Allocation Committee (FAAC), which

\footnotetext{
${ }^{8}$ Source: Author calculations from archival data. Details provided in Section 4.
} 
meets monthly to allocate the previous month's revenue among the three levels of government $^{9}$ (Maystadt and Salihu, 2019). Despite the ostensibly rule based nature of revenue sharing, there is virtually no information released by the federal government on the data components used in the formula.

At the state level, while data on allocation transfers, making up over $60 \%$ of state revenues, are regularly publicized in media and federal documents ${ }^{10}$, data on VAT transfers to states are much less transparent, with very little information shared by the federal government on the components and determinants of VAT transfers. Figure 1 shows Google Trends search rankings for 'allocation' versus 'VAT' terms in Nigeria between 2011 and $2021^{11}$ and provides suggestive evidence of the relatively more well publicized nature of allocation versus VAT transfers in Nigeria. The top 5 most related search query terms for allocation and VAT in Nigeria in Table A1 in Appendix A.1 also provide further suggestive qualitative evidence that Nigerian residents have a higher level of knowledge/information about allocation transfers than VAT transfers; residents are more likely to search questions about the distribution of allocation transfers and the definition of VAT. The lack of transparency, combined with relatively weak institutions around monitoring leakages in Nigeria has made the Federation Account transfers a source of contention, and susceptible to political manipulation, despite the formula based nature of revenue sharing in the country (Maystadt and Salihu, 2019; Ekpo, 1994; Salami, 2011); echoing issues identified with formula based fiscal schemes in other countries in the region (Banful, 2011). It also allows us to examine how federal governments may use the transfer system to respond to protests within the country, despite the

\footnotetext{
${ }^{9}$ The committee consists of the Federal Minister of Finance, state representatives and representatives from the Central Bank and Federal Inland Revenue Service, among others. See Maystadt and Salihu (2019) for details.

${ }^{10}$ For example, as highlighted in this BBC news article written in one of the local languages, Nigerian pidgin: https://www.bbc.com/pidgin/media-53470429

${ }^{11}$ The figure looks similar if we examine trends from the earliest available date in 2004, though after 2010, Google reports that there was a reassessment of the data for geographic location accuracy so we report trends after the reassessment in 2010.
} 
formula.

\subsection{Protests and Government Responses}

\subsubsection{Military Rule}

Many protests have been highlighted throughout Nigeria's history of military rule. To illustrate the different ways in which governments responded to protests, we highlight one here: the so-called 'economic riots' of the Structural Adjustment Program (SAP) era of the 1980s and 1990s (Shettima, 1993). Over the debt crisis of the 1980s, Nigeria was one of a group of African countries that qualified for loans from international financial institutions like the International Monetary Fund (IMF) and the World Bank. The loans were under strict conditions that stipulated that countries needed to implement more free-market based policies to qualify for debt relief under so-called Structural Adjustment Programs (SAP) (Archibong, Coulibaly, and Okonjo-Iweala, 2021). Some of the SAP policies, like the removal of agricultural subsidies that kept food prices low, led to increases in food prices that were blamed for the stagnation of economic growth and increases in youth unemployment and poverty over this period (Archibong, Coulibaly, and Okonjo-Iweala, 2021; Sender, 1999).

The poor economic conditions sparked a number of university student and labor union led protests over the 1980s and 1990s, and were labelled "economic riots" in international news reporting ${ }^{12}$ (Sneyd, Legwegoh, and Fraser, 2013; Shettima, 1993). Poor economic conditions coupled with periodic non-payment of salaries of public sector workers were often highlighted as grievances against government as unions organized these workers to protest non-payment of salaries and for an improvement in work conditions (Shettima, 1993). The responses from the military government were a combination of concession/appeasement, in the form of transfers, like salary payments to workers, and repression- beating, arrests and

\footnotetext{
${ }^{12} \mathrm{~A}$ headline from the New York Times from this period is shown in Figure A5.
} 
killing of protest participants (Shettima, 1993).

\subsubsection{Democratic Period}

As in the military period, the drivers of protest over the democratic period in Nigeria have been varied, with the common theme being protests around economic conditions led by labor unions and protests around economic and political conditions led by opposition party leaders in the country (Sneyd, Legwegoh, and Fraser, 2013; Bellemare, 2015; Omotola, 2009). As in the military period, poor economic conditions coupled with periodic non-payment of salaries of public sector workers are often highlighted as reasons for protests, with unions organizing workers from teachers to healthcare workers to protest against government non-payment of salaries and for an improvement in working conditions ${ }^{13}$ (Adeloye et al., 2017).

Three notable protests in the past few decades include the 2007 electoral protests, the 2012 Occupy Nigeria fuel subsidy protests and the 2020 End SARS protests. The 2007 electoral protests followed the election of then president Umaru Yar'Adua and perceptions that the voting was rigged, and that the incumbent party, the People's Democratic Party (PDP) that had been in power for all of the democratic period at the time, had not done enough to improve economic conditions in the country (Omotola, 2009). The 2012 Occupy Nigeria protests followed the removal of long standing fuel subsidies which led to an overnight spike in gasoline prices in the country (Akanle, Adebayo, and Adetayo, 2014). The most recent protest- the 2020 End SARS protests was partly inspired by the BLM anti-police brutality protests ${ }^{14}$. The protests centered around calling for an end to police brutality spearheaded by one police unit in particular, the Special Anti-Robbery Squad (SARS), against local populations. The responses to these protests from the Nigerian government have been, as they were under military rule, a mixture of concession/appeasement, generally in the

\footnotetext{
${ }^{13}$ An example from recent newspaper headlines highlighting protests of government workers over nonpayment of salaries is shown in Figure A6 in Appendix A.2.

${ }^{14}$ Source: https://www.bbc.com/news/world-africa-54662986
} 
form of economic transfers to groups or retractions of policies, and repression through statesponsored violence and security clampdowns ${ }^{15}$ (Bratton and Van de Walle, 1992; Branch and Mampilly, 2015).

\section{Conceptual Framework}

As illustrated in the historical accounts in Section 2.2, the response to protests by federal governments is generally two-fold: a combination of concession/appeasement and repression focused tactics with the aim of quelling protests that may threaten the federal government leader's tenure in office. To fix ideas about the links between protests and intergovernmental transfers, we outline a simple conceptual framework as follows. In a principal-agent framework, there are two actors operating under a revenue sharing fiscal system: the principal is the federal government leader, $f$, with full control of disbursement over centrally collected revenues $R$ and the agent is a state government leader dependent on $f$ for revenue transfers. The objective of $f$ is to maximize tenure in office either through minimizing the risk of coups under military governments or maximizing the probability of re-election under democratic regimes. This requires some level of cooperation or effort from state government leaders to quell protests that can jeopardize $f$ 's tenure in office. Assume agents cannot be perfectly monitored and the principal must motivate them by sharing $\theta R$ with them. We consider a subset of cases where the total level of $R$ within the country is exogenously determined, as in the case where federal government revenues come from natural resources like oil, with the value of $R$ dependent on external natural resource price shocks.

Suppose there are $n$ agents, and $e_{i}$ refers to agent $i^{\prime} s$ effort, with $i=1, \ldots, n$, and $e_{i} \in(-\infty,+\infty)$. The agent $i$ can choose to exert $e_{i} \geq 0$ and assist $f$ in quelling protests $\left(e_{i}>0\right)$ or choose to do the opposite and work against $f$ 's objectives by supporting or inciting

\footnotetext{
${ }^{15}$ Incidentally, the similarity of response from federal governments under democratic rule may not be surprising given that $30 \%$ of democratic presidents were also military heads of states in Nigeria.
} 
further protest $\left(e_{i}<0\right)$. The cost of effort to agent $i$ is $c\left(e_{i}\right)$ which we assume to be increasing and convex with $c(0)=0$.

Under a revenue sharing scheme, agent $i^{\prime} s$ transferred revenue is composed of a share $\theta_{i}$ of the federally collected natural resource revenues. $\theta_{i}$ is defined such that for $\left(\theta_{1}, \theta_{2}, \ldots, \theta_{n}\right)$, $\theta_{i} \geq 0$ for all $\mathrm{i}$ and $\sum_{i} \theta_{i} \leq 1$.

The principal's objective function when the agent exerts effort $e$ is:

$$
\max _{\theta_{i}}\left(1-\theta_{i}\right) R(p, \delta) e_{i}
$$

where $R($.$) is a strictly increasing function of exogenous natural resource prices p$ and $\delta$ is a stochastic component of natural resource revenues ${ }^{16}$. The corresponding agent $i^{\prime} s$ function is:

$$
\max _{e_{i}}\left(\theta_{i}\right) R(p, \delta) e_{i}-c\left(e_{i}\right)
$$

and agent $i$ chooses effort, $e_{i}^{*}$, so that

$$
\frac{d}{d e_{i}}\left(\theta_{i} R(p, \delta) e_{i}-c\left(e_{i}\right)\right)=0
$$

and

$$
\theta_{i}=\frac{c^{\prime}\left(e_{i}^{*}\right)}{R(p, \delta)}
$$

$R(p, \delta)$ is some constant term that we can assume, WLOG, equals one.

Prediction 1: A mechanical implication of Equation 4 is that an increase in the marginal

\footnotetext{
${ }^{16}$ Assuming the principal's country is a price-taker, $\delta$ can include factors like political instability, causing price shocks in natural resource markets.
} 
cost of the agent's effort in complying with the principal's objectives, all else equal, will be associated with an increase in the share of revenues transferred to the agent.

Prediction 1a: A follow up to Prediction 1 is that the principal may transfer a greater share of revenues to agent $i$ when $e_{i}^{*} \geq 0$, but will reduce transfers to $i$ when $e_{i}^{*}<0$.

We argue here that under a system of heterogeneous political preferences of principals and agents, reflected by, for example, political party systems, agents that share the same political preferences as the principal, i.e. who are from the same political party as the principal or politically aligned with the principal, have an incentive to keep the principal in office and will exert non-negative effort to do so; one way they might do this is by facilitating transfers to satisfy the unpaid salary demands of protesting public sector workers as highlighted in Section 2.2. In contrast, agents who are not from the same political party and hence have incentives to remove the principal from office may exert $e_{i}^{*}<0$, by, for example, funding media campaigns to criticize the principal for poor economic conditions and unpaid public sector salaries or funding fellow opposition party members involved in protests to further fuel protests and signal dissatisfaction with the principal's party as highlighted in the electoral protests case described in Section 2.2. Accordingly, Prediction 1a will hold for these agents. Important to note here is that since the principal imperfectly monitors agent effort, Prediction 1a still holds if the principal only assumes or perceives negative agent effort.

Additionally, areas with higher levels of protests may have greater numbers of people with enough social capital to mobilize communities for protest, which makes it more politically costly for agents to quell protests in these regions (Bratton and Van de Walle, 1992). Accordingly, agents in these regions may need to exert more effort to quell protests, in line with the principal's objectives, and may need more resources to do so, so Prediction 1 will hold and transfers will increase in the marginal cost of agent effort. Key here is that $f$ will 
respond to protests with transfers of $\theta_{i}$, based on the marginal cost of agent effort, but not to other events, like armed conflicts, battles or civil wars in states. This is because citizen-led protests against governments directly reveal citizens' relatively higher levels of social capital, reflected in their ability to mobilize against the government through protests that can threaten the principal's objective of maximizing tenure in office. Areas with higher levels of social capital, among less fractionalized populations where the costs of coordinating protests are lower, may experience high levels of protests that clearly signal this social capital to regimes, especially during economic downturns (Enikolopov, Makarin, and Petrova, 2020; González, 2020). In contrast, other citizen to citizen conflict events like battles between citizens or civil war, instead signal low levels of social capital and polarized populations that do not threaten f's objective (Montalvo and Reynal-Querol, 2005).

In the Nigerian context, the principal is the federal government leader or president and the agent is the state government leader or governor. Under military rule, all agents or state governors are politically aligned since state governors were military president appointees. In contrast, under democratic regimes, political alignment is signaled by party alignment between state government leaders and the federal government head, following results from the electoral politics literature (Ellman and Wantchekon, 2000; Cox and McCubbins, 1986).

\section{Description of Data}

\subsection{Public Finance}

To assess the effects of protests on fiscal transfers from the federal government, we digitized twenty-six years of archival data on state revenues and expenditures from the Nigerian Annual Abstract of Statistics (AAS) and Ministry of Finance FAAC Reports between 1988 and 2016. The AAS are statistical reports submitted on an annual basis and contain data on allocation and VAT transfers, IGR and recurrent and capital expenditures at the state 
level from 1988 to $1996^{17}$. An example of the archival data from the AAS reports is shown in Figure 2. The FAAC reports report monthly and total yearly transfers and allocations to states from 2000-2016, and we use the data at the yearly level for comparison with the pre-2000 military period ${ }^{18}$. These data sources and the variables we use in our analysis are described in detail in the data appendix in Appendix A.1.1.

Figure 3 and Figure 4 show maps of Nigeria with its states outlined, and the shares of VAT and allocation transfers and IGR in total state revenues over the military period for available data from 1988 to 1996 and the democratic period from 2000 to 2016. The spatial distribution of state revenues has remained relatively stable between the military and democratic periods, reflected in the significant positive correlations between state revenues in the military and democratic periods. The correlation between state revenues in both periods is largest for IGR at $0.66(p<0.001)$, followed by VAT transfers $(0.61, p<0.001)$ and allocation transfers $(0.51, p<0.01)$. In contrast, the trends in capital and recurrent expenditures at the state levels between the military and democratic periods are significantly weaker; the correlation in capital expenditures between both periods is positive and weakly significant at $0.33(p<0.1)$ and positive but statistically insignificant for recurrent expenditure $(0.27$, $p=0.13)$. As documented in previous work and discussed in Section 2, increases in plausibly exogenous oil prices are strongly positively associated with average allocation $(0.7, p<0.001)$ and VAT $(0.61, p<0.01)$ transfers to states (Maystadt and Salihu, 2019).

As mentioned in Section 2, transfers from allocations and transfers make up most of state revenues, with allocation transfers comprising $65 \%$ of total state revenues over both the military and democratic periods. VAT transfers make up $14 \%$ and $16 \%$ of total state revenues in the military and democratic eras respectively. There are no clear spatial patterns in the distribution of transfers, with transfers featuring more or less prominently in total state

\footnotetext{
${ }^{17}$ There is no available complete public finance data between 1997 and 1999.

${ }^{18}$ The yearly data is also more complete than the monthly data so we use the reported yearly data here.
} 
revenues in different regions of the country. In contrast, internally generated revenues appear to make up a larger share of total state revenues in Nigeria's relatively wealthier southern states as shown in Figure $4^{19}$. While there is no detail provided on the breakdown of the state expenditures, $65 \%$ and $56 \%$ of total state spending come from recurrent expenditures in the military and democratic periods respectively; the corresponding figures for capital expenditures are $35 \%$ and $44 \%$. Table A2 in Appendix A.1 provides a detailed summary of the public finance statistics.

\subsection{Protests}

To measure protests, we use two sets of geocoded data spanning the time period of our public finance data from 1988 to 2016. For protests from the democratic period between 2000 and 2016, we employ data from the widely used Armed Conflict Location and Event Data (ACLED) project which provides geocoded data on conflict events from media, newspaper and news agency sources (e.g. The Washington Post, The Associated Press, etc.), starting in 1997 (Raleigh et al., 2010). There are eight conflict event categories recorded in the ACLED database including organized group "battles" among others; our main variable of interest is the "protests and riots" category which we refer to as protest here. Since ACLED does not contain data from the military period from 1988 to 1996, we use another dataset, the Global Data on Events Location and Tone (GDELT) project, which similarly records geocoded data on conflict and mediation events similarly extracted from media and news agency sources over the 1979 to 1999 military period in our sample (Ward et al., 2013). GDELT includes twenty main event categories, including classifications like organized group "fights" or battles and, our main variable of interest, "protest", including reported protest and riot events. For

\footnotetext{
${ }^{19}$ Located in the country's southern region, Lagos and Rivers states were the only states where IGR, not transfers, made up the the majority of state revenues. $68 \%$ and $61 \%$ of Lagos state's revenue came from IGR in the military and democratic eras respectively, while the corresponding figures for Rivers state were $53 \%$ and $63 \%$ as shown in Figure 4. The results outlined in Section 5 are robust to the exclusion of these two states.
} 
the period of ACLED/GDELT data overlap, from 1997 to 1999 in our sample, there is a high, significant positive correlation between the number of protests recorded in the ACLED and GDELT datasets of $0.86(p<0.001)$.

Following the framework outlined in Section 3 and the historical accounts in Section 2, federal government leaders respond to local protests that are in high enough numbers to be notable within the country and require higher levels of state government effort to quell. We define 'high, notable protests' or protest intensity at the state level in two ways. First, as the state-level deviation of the numbers of protest events in each state from the national average numbers of protest events in each year or the state-level z-scores relative to the national mean within a particular year ${ }^{20}$. The specification captures the relative intensity of protests within a state, and the sensitivity of federal government responses to marginal deviations in a state's level of protests from the national average. The second measure defines protest intensity at the state level as strictly positive deviations from the national mean, or as an indicator that equals one if the state's protest z-score is greater than zero. This measure provides an extensive margin estimate that captures the federal government response to relatively high versus low levels of protests within states. Other conflict measures, like battles, are defined similarly to the protest measures. Figure 5 shows the spatial distribution of the long-run averages of the protest and battles intensity indicator measures in the military and democratic periods. We primarily interpret results from the continuous z-score protest intensity measure, and provide the indicator results as an alternate measure of protest intensity.

There is a positive correlation $(0.65, p<0.001)$ between the protest intensity likelihood, measured as the long-run average of the protest intensity indicator, in the military and democratic periods. Details about protest locations are provided in Appendix A.2. The

\footnotetext{
${ }^{20}$ Measured as $\frac{\left(x_{i t}-\bar{x}_{t}\right)}{\sigma_{t}}$ where $x_{i t}$ is the sum of protest events in state $i$ at time $t, \bar{x}_{t}$ is the average number of protests in year $t$ and $\sigma_{t}$ is the standard deviation.
} 
ACLED and GDELT datasets also list actors involved in protests for a small $(<10 \%)$ subset of the data. The top three, non-state security forces, actors involved in protests in the democratic period from 2000 to 2016 are labor unions/workers, students and political party members. The GDELT categories are less detailed than their ACLED counterparts, with the top actors for protest participants in the military period listed as 'Nigerians' against the 'government'.

\subsection{Political Parties}

To test hypotheses around the role of political alignment as a potential channel linking protests and revenue transfers, outlined in the framework in Section 3, we assemble a dataset of the political parties of state governors and presidents from 2000 to 2016 from publicly available data from various sources ${ }^{21}$. While at the presidential level, two parties, the People's Democratic Party (PDP) and, more recently, the All People's Congress (APC), have dominated presidential elections, with the president coming from PDP in $88 \%$ of years from 2000 to 2016, state level, gubernatorial elections have historically been a more competitive landscape. Between 2000 and 2016, ten parties have elected governors into office in Nige$\mathrm{ria}^{22}$. State electoral politics often assume a very local character, with ethnic/ethnoregional politics playing a major role in citizen preferences over parties in gubernatorial elections $(\text { Azeez, 2009) })^{23}$. This translates to notable heterogeneity in the likelihood of a governor being politically aligned with the president as shown in Figure 6. Notable after 2010, is the drop in the likelihood of governor-president party alignment, following the sudden death of

\footnotetext{
${ }^{21}$ Details are provided in Appendix A.3. There is no publicly available complete data on vote shares over the 5 electoral years between 2000 and 2016 in Nigeria.

${ }^{22}$ Table A3 shows the distribution of parties over time. Gubernatorial elections are concurrent with presidential elections in approximately $87 \%$ of years over the democratic period. State governor party affiliations are largely stable over time; only in $1.5 \%$ of cases in the democratic sample do individual governors switch parties for reelection. And in $56 \%$ of those switches, the governor switches to an opposition party from the president's party or from one opposition party to another.

${ }^{23}$ As mentioned in Section 2, geographies correlate strongly with ethnicity in Nigeria, which in turn correlate strongly with local party politics in the country (Azeez, 2009).
} 
then president Umaru Yar'Adua and the appointment of the first ever president from the south-south ethnic region, then vice-president Goodluck Jonathan. The appointment was met with subsequent electoral backlash in the southwest ethnic region in the 2011 elections, with PDP partly losing gubernatorial elections to a rival southwest ethnic region voting base heavy opposition party, the Alliance for Democracy $(\mathrm{AD})^{24}$. Further details on party politics in Nigeria are provided in Appendix A.3.

\section{Protests and Fiscal Redistribution}

\subsection{Protests and Intergovernmental Transfers}

We can examine the relationship between protests and intergovernmental transfers by estimating the following equation:

$$
y_{s t}=\phi \text { Protest }_{s t}+\mu_{s}+\delta_{t}+\epsilon_{s t}
$$

where $y_{s t}$ is the outcome of interest for district or state $s$ at year $t$. The main outcome of interest is total transfers (allocation or VAT) to state $s$ in year $t$. This specification includes a set of unrestricted within-country district or state fixed effects, denoted by $\mu_{s}$, which capture unobserved differences that are fixed across states, like population levels and geographic characteristics like landmass and terrain that are determinants of the standard formula for transfers as described in Section 2.1. The year fixed effects, $\delta_{t}$, control for changes in national policies (e.g. fiscal policies) and other macro factors. Standard errors are clustered at the state level to allow for arbitrary correlations, and all regressions include both district and year fixed effects.

As described in Section 4.2, we measure "Protest" in two ways. Our main measure

\footnotetext{
${ }^{24}$ As shown in Figure A7 in Appendix A.3.
} 
is the Protest (Continuous) measure, which is the z-score, calculated as state level total number of protests deviation from the national mean level of protests within a year to capture the relative intensity of protests. To examine the sensitivity of government responses to significantly high, above country average levels of protest within states, we construct a Protest (Indicator) measure that is an indicator that equals one if the Protest (Continuous) measure is greater than zero. An important note here is our protest measure is not simply measuring the numbers of protests but capturing the relative number of protests to test the hypothesis in Section 3 that federal governments will respond to relatively high, notable levels of protests within a state, not just the raw numbers.

While we show balance across a number of geographic and institutional state characteristics of the protest measure in Table A4 in Appendix A.4, we interpret the results from Equation 6 as robust correlations due to the possible endogeneity of the protest measure.

\subsubsection{Mechanisms: The Role of Political Alignment}

To test the hypothesis presented in Section 3, that the primary channel linking protests and intergovernmental transfers is political alignment with federal governments increasing transfers to aligned states and reducing transfers to non-aligned states, we estimate Equation 6 below:

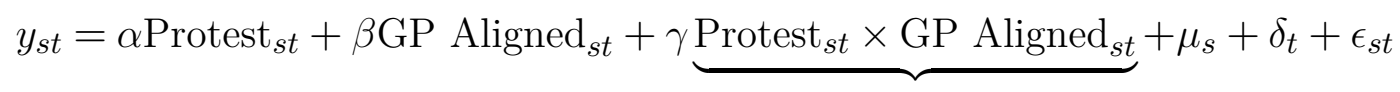

where "GP Aligned" is an indicator that equals one if the president and state governor come from the same political party. Note, that as mentioned in Section 3, during the military period, "GP Aligned" is always equal to one and Equation 6 estimates the same model as 
Equation 5, since state governors are military president appointees.

Our key parameter of interest $\gamma$ (where $\gamma$ in Equation 6 equals $\phi$ in Equation 5 during the military period) provides a statistical test of the difference in transfers in aligned versus non-aligned areas.

\subsection{OLS Estimates}

Figure 7 shows average VAT and allocation transfers in each year from 2000 to 2016. Trends in the raw data point to higher transfers in protesting areas, though with notably more variance among the less publicized VAT transfers than the more publicly announced allocation transfers, following the account in Section 2.1. We present the OLS estimates for the effects of protests on intergovernmental transfers over the military period in column (1), (2), (4) and (5) of Panel A of Table 1. We present a falsification test using internally generated revenue (IGR) as the outcome in column (3) and column (6) of Panel A. All revenue outcomes are log real (2010 Nigerian Naira) values. For inference robustness and to account for potentially low numbers of clusters, we also report wild cluster bootstrap p-values derived from running 1000 replications in each instance. The results from our main measure of protest, the continuous protest z-score, indicate that protests are significantly positively associated with both VAT and allocation transfers, but not with IGR. Column (1) of Panel A indicates that a one standard deviation increase in a state's number of protests, relative to the national mean, increases the VAT transfers to the state by $5.2 \%$. A one standard deviation increase in protest intensity increases the allocation transfers to states by $6.8 \%$. The results are similar when we examine the effects of protests using the indicator measure in column (4) and column (5) of Panel A. High intensity protests, as measured by the indicator, increase VAT transfers by $11.5 \%$. The effects are particularly robust for VAT transfers, the less public category of intergovernmental transfers. 
As a falsification test, to check that the protest effect results in Panel A of Table 1 are not driven by other conflict events occurring in the state, we examine the relationship between events coded as "Fights" or armed group battle events in the GDELT data and the intergovernmental transfer and IGR outcomes. We refer to this category as battles here. There is no robust association between battles recorded within a state and intergovernmental transfers as shown in Panel B of Table 1. When we assess all conflict and mediation events registered in the GDELT database within a state, the results in Panel $\mathrm{C}$ show no robust links between general event intensity and transfers to states; high event intensity is positively associated with IGR in column (6) of Panel C.

We estimate Equation 5 for the democratic period and examine the effects of protests on intergovernmental transfer and IGR outcomes. Table 2 reports estimates of the effects. Using the continuous protest measure, protests are weakly positively associated with VAT transfers in column (1) of Panel A. Protests are significantly negatively associated with allocation transfers to states in column (2) and column (5) of Panel A. Specifically, a one standard deviation increase in a state's number of protests, relative to the national mean, decreases allocation transfers by a small, but significant point estimate of $0.5 \%$. High intensity protests, as measured by the indicator, decrease allocation transfers by $0.7 \%$. There is no robust association between battles or other conflict events recorded within a state and intergovernmental transfers as shown in Panel B and Panel C, respectively, of Table 2. To what extent does variation in political alignment between state governors and presidents in the democratic period rationalize the differing results for the relationship between protests and transfers in the democratic period? To answer this, we estimate Equation 6 and examine heterogeneity in the effects of protests on transfers by party alignment.

The results are shown in Table 3. Panel A of Table 3 reports estimates of the effects of protests on transfers and IGR by political alignment status of state governors and presidents. 
Column (1) of Panel A indicates that while protests are negatively associated with VAT transfers in non-aligned areas, they are positively associated with transfers in aligned areas. A one standard deviation increase in a state's protest intensity relative to the national mean increases VAT transfers to that state by $4 \%$ over the democratic period. High intensity protests, as measured by the protest indicator, increase VAT transfers by $6.6 \%$ (column (4) of Panel A). Inversely, in non-aligned states, a one standard deviation increase in a state's relative protest intensity is associated with an $1.1 \%$ decrease in VAT transfers to the state. Similarly, the negative association between protests and allocation transfers are driven by reduced transfers to non-aligned states in column (2) and column (5) of Panel A. There is no association between battles and transfers by political alignment in Panel B. Political alignment in general is also positively associated with higher levels of VAT transfers.

\subsection{Instrumental Variable Estimates}

The results presented in Table 1, Table 2 and Table 3 suggest that there are significant correlations between protests and intergovernmental transfers. Examining battles and other conflict outcomes also helps us partly address concerns of reverse causality, with the idea that if transfers increase protests through conflict over resources, they should increase conflict generally within the country. However, this does not identify the causal effect of protest on intergovernmental transfers, and there may still be concerns about reverse causality. Additionally, given the accounts of protests being driven by economic conditions in Section 2.2, it is possible that there is an omitted variable that both determines protests and intergovernmental transfers. To address this concern, we present results using an instrumental variables (IV) approach. A relevant instrument will predict a state's protest intensity but will not affect intergovernmental transfers through any other channel than through protests.

As mentioned in Section 3, there is a growing social science literature on the causes of protests that has highlighted the costs of coordination and the role of economic downturns 
as being important joint drivers of protests (Enikolopov, Makarin, and Petrova, 2020; Manacorda and Tesei, 2020; Battaglini, 2017; Madestam et al., 2013). Guided by this literature, we construct an instrument that is the interaction between two components: (1) the level of ethnolinguistic similarity in a state and (2) the share of states experiencing a negative economic shock within the year. The interacted instrument takes the form in Equation 7

Ethnolinguistic Similarity x Negative Shock Year $_{s t}=\mathrm{ES}_{s} \times\left[\frac{1}{N} \sum_{n=1}^{N} N S_{n}\right]_{t}$

where Ethnolinguistic Similarity measures the degree of linguistic similarity, measured by linguistic distance between ethnic groups in state $s$, and Negative Shock Year is the proportion of states experiencing a negative economic shock within the year, defined relative to extreme rainfall shocks. We first explain the logic behind each component, and then any discuss potential concerns with the instrument and how we address them.

The first component of the instrument addresses the cost of coordination for protest, and is the degree of ethnolinguistic similarity measure adapted from Gershman and Rivera (2018)"s ethnolinguistic diversity, $E L F_{\delta}$ based on the widely used ethnolinguistic fractionalization $(\mathrm{ELF})$ measure $^{25}$. which captures the probability that . The $E L F_{\delta}$ value measures the level of ethnolinguistic diversity within regions at different distance parameters $\delta . \delta$ can vary between 0.01 to 1 , with higher values of $\delta$ signifying greater weight given to linguistic distance between groups. We choose $\delta$ equal to 0.2 to more strongly capture linguistic distance between ethnic groups in $s^{26}$. We adapt the Gershman and Rivera (2018) mea-

\footnotetext{
${ }^{25} \mathrm{ELF}$ "captures the probability that two randomly chosen residents in the region below to distinct ethnolinguistic groups" (Gershman and Rivera, 2018).

${ }^{26}$ Our results are robust to marginal changes in the choice of $\delta$, with tables available upon request. See Gershman and Rivera (2018) for details on the ethnolinguistic diversity measure, and we provide further details in Appendix A.5.
} 
sure by multiplying it by -1 so that higher values represent more ethnolinguistic similarity. The ethnolinguistic similarity measure captures the fact that language may be a significant barrier to collective action for protest, inasmuch as it represents a barrier to easy communication. Regions with more people from ethnicities that speak the same language may have an easier time of communicating to organize for protests. There is also relatively little inter-district migration in Nigeria as has been documented in other work (Archibong, 2019; Nunn and Wantchekon, 2011), with significant and high levels of correlation $(0.7, p<0.001)$ documented between the locations of ethnic groups in the precolonial period (c. 1850) and contemporary data from 2000 to 2014 (Archibong, 2019; Nunn and Wantchekon, 2011). Using ethnolinguistic similarity, rather than just ethnic fractionalization also allows us to plausibly test that the instrument affects protests through effects on communication as the primary channel.

The second component of the instrument addresses the role of economic downturns in spurring protests, and is the share of states that experienced a negative economic shock within the year. A major share of workers are employed in agriculture in Nigeria ${ }^{27}$. Agriculture is primarily rain-fed with irrigated agriculture accounting for only $1 \%$ of cultivated area in the country (Xie, You, and Takeshima, 2017). The combination of these facts means that economic conditions of domestic populations are sensitive to sudden unexpected changes in rainfall that may reduce crop yields and respective agricultural incomes (e.g. through droughts or floods) (Archibong and Obikili, 2020). We use satellite data on precipitation from the NASA MERRA-2 dataset, and adapt the strategy from Archibong and Obikili (2020) to estimate extreme rainfall shocks that reduce crop yields relative to cutoffs in a district's yearly rainfall deviation from its long-term mean over 1980 to 2016. Following evidence from crop yield data and the agricultural literature outlined in Archibong and

\footnotetext{
${ }^{27}$ Estimates range between $37 \%$ and $70 \%$ as of 2016 by World Bank and Food and Agriculture Organization (FAO) statistics respectively.
} 
Obikili (2020), we then define a district as having experienced an extreme rainfall shock if it has experienced a drought or flood in that $\operatorname{year}^{28}$. We estimate the share of districts that have experienced extreme rainfall shocks in a particular year and use this as our measure of a "Negative Shock Year", with higher values indicating worse economic years or economic downturns. The value ranges between 0 and 1 , where 0 is no states experiencing shocks in the year and 1 is all states experiencing extreme rainfall shocks in the year. Reassuringly, our negative shock year measure is significantly negatively correlated with GDP growth, particularly in the democratic period $(-0.63, p<0.001)$.

Given concerns that the instrument may directly affect intergovernmental transfers or that it may affect transfers through a channel other than protests, we also present two falsification tests for the instrument. The first falsification test leans on the assumption that the interacted instrument is capturing lowered costs of coordination with ethnolinguistic similarity that allows for easier communication to organize protests during economic downturns when people may have more grievances against the government as a result. The reduced costs of coordination requires that people who speak the same language actually have a way to speak to each other easily and share information over potentially large distances to organize or mobilize protests more efficiently. Information and communication technology (ICT), and in particular mobile phones, help facilitate this process (Manacorda and Tesei, 2020). So our interacted ethnolinguistic similarity instrument should predict protests strongly only in areas that have achieved some threshold level of mobile phone penetration if the communication channel is correct. Since in Nigeria, before 2000, mobile cellular subscriptions per 100 people was essentially 0 before rising to 83 per 100 people in 2016 by World Bank estimates, our interacted ethnolinguistic similarity instrument should not strongly predict protests over the military period before the introduction of mobile phones. In the democratic period, it should

\footnotetext{
${ }^{28}$ Droughts and floods are defined as in Archibong and Obikili (2020), an an indicator equals one if the district's rainfall deviation z-score is $>0.75$ (floods) or $<-0.5$ (droughts). See Archibong and Obikili (2020) for details.
} 
more strongly predict protests in states that have achieved some threshold level of mobile phone penetration where same language speaking residents can benefit from communication network externalities to more easily organize protests during economic downturns.

The second falsification test is that our interacted ethnolinguistic similarity instrument should positively predict protests but not intergroup armed conflict like battles if people from similar groups are more cooperative and less likely to fight with each other (Montalvo and Reynal-Querol, 2005). Table 4, along with Table A6 and Table A7 in Appendix A.5, presents the results from both falsification tests. The interacted ethnolinguistic similarity instrument strongly predicts protest, but only in the democratic period after the introduction of mobile phones. Within the democratic period, the association between the instrument and protests is stronger in states with some threshold level of mobile phone ownership (Table A.5). The instrument is negatively associated with battles in both the military and democratic periods (Table A6). These results, along with further falsification tests examining the reduced form relationship between the interacted ethnolinguistic instrument and intergovernmental transfers in Section 5.4 suggest that the interacted ethnolinguistic similarity with negative shock year instrument does not directly affect intergovernmental transfers.

Panel A of Table 5 presents the first stage estimates for the instrument- using the interaction between ethnolinguistic similarity and the share of states experiencing negative economic shocks in the year. The instrument predicts the continuous protest intensity measure, with an F-stat over 10 in all specifications. Panel B of Table 5 presents the second stage estimates with VAT transfers as the outcome in column (1) and column (2) and allocation transfers as the outcomes in column (3) and column (4). The comparison OLS estimates are shown in Panel C. The second stage OLS estimates suggest that a one standard deviation increase in a state's relative protest intensity decreases allocation transfers by $2 \%$ on average, compared to the close, but slightly lower $0.5 \%$ decrease predicted by the OLS estimates in 
column (3) and column (4) of Panel C. The point estimates in the second stage for the VAT transfers are imprecisely measured, an issue that can arise with small sample sizes in IV regression (Angrist and Krueger, 2001), but qualitatively similar to the OLS estimates in the specification in column (2), which includes controls for political alignment ${ }^{29}$.

\subsection{Other Falsification Tests}

One concern with the results from Section 5.3 is that the suggested instrumental variable does not satisfy the exclusion restriction. In other words, that ethnolinguistic similarity interacted with negative shock year might affect intergovernmental transfers through channels other than protests. Given that the instrument is an interaction of two separate terms, this is less of a concern here, but given possible concerns about the violation of the exclusion restriction, in addition to the two falsification tests exploiting the distribution of mobile phone technology within Nigeria and over time and using battles as a check, we can also examine the reduced form effect of the interacted ethnolinguistic similarity instrument on transfers. We can also examine if, following the results on political alignment in, Table 3, we find similar results on alignment using the interacted ethnolinguistic similarity instrument. Table 6 presents the results for the reduced form estimates. For VAT transfers, there is no relationship between the instrument and VAT transfers across all specifications in column (1) to column (3). For allocation transfers, though the instrument is negatively associated with allocation transfers in column (4) and (5), the magnitudes are notably larger than the magnitudes estimated in Table 3 and the association is not robust to the inclusion of controls political alignment in column (6). Thus the falsification tests presented in Section 5.3 and Table 3 suggest that the instrument does not directly affect transfers.

\footnotetext{
${ }^{29}$ We encounter similar issues around small sample sizes when trying to instrument to estimate equations including the interaction term for political alignment in Table A8. The results including the interaction term are largely qualitatively similar, but with imprecise point estimates in the second stage.
} 


\section{Examining Policing and State Expenditure Outcomes}

\subsection{Policing}

The results presented so far provide evidence that federal governments respond to protests by redistributing fiscal transfers, in line with the framework in Section 3. Another important way governments may respond to protests is through increased repression, employing statesponsored violence against protesters following the historical accounts in Section 2.2. The Nigerian Police Force is a national body, as designated by Nigeria's 1999 constitution, under the general operational and administrative authority of an Inspector General appointed by the president and charged with maintaining security in the country (Akuul, 2011). The police are also a primary instrument of state violence, a fact which was a major driver of protests in the anti police brutality End SARS movement described in Section 2.2. To test the hypothesis that governments may also respond to protests by increasing state-sponsored violence against protesters, we examine whether protests are associated with more policing, measured as the share of police among protest actors documented in the ACLED data. The ACLED data over the democratic period provides the most detailed record of actors in protests as discussed in Section 4, so we report results from this dataset here. Since more policing does not necessarily mean more police violence, we check the ACLED notes for qualitative details from newspaper accounts coded by independent researchers describing actions of police towards protesters. While the notes are usually unique, non-repeating entries, the most frequently occurring note, repeated at least six times in the notes sample, is "Police disperse protest violently". 58\% of cases involving police as actors during protests documented in the notes, include mentions of police firing tear gas, shooting, killing, or otherwise clashing with protesters. The notes provide suggestive evidence that a higher share of policing in protesting areas is associated with more police violence against protesters. 
As a falsification test, we examine the share of other major actors in protests, including the military, political parties, and labor unions ${ }^{30}$. We also examine the share of these actors in battles, following the previous specifications. Table 7 reports the estimates of the effects of protests on policing using the continuous measures of protest intensity. The results in Panel A show that protests are strongly positively associated with policing. A one standard deviation increase in the protest measure increases policing by $2.6 \%$ on average (column (1) of Panel A). The effects differ significantly for politically aligned versus non-aligned states as shown in column (2) of Panel A. While protests are associated with an increase in policing in non-aligned areas, they are associated with reduced policing in politically aligned states. There is no effect of protests on the share of military actors involved (column (3) and column (4) of Panel A). Column (5) and column (6) of Panel A present suggestive evidence that protests are associated with increased political party actor involvement, particularly in nonaligned states (column (6)). In other words, political parties tend to comprise relatively higher shares of participants in protests in non-politically aligned states, in line with the historical account in Section 2.2 and the framework in Section 3.

Panel $\mathrm{B}$ reports the results of the falsification test examining the effects of battles on policing and the other actor involvement. There is no significant association between battles and policing as shown in column (1) and column (2) of Panel B. Battles are strongly associated with increased military involvement (column (3) and column (4)), and significantly negatively associated with political party involvement (column (5) and column (6)). Taken altogether, the results in Table 7 suggest that protests increase policing and police violence against protesters, particularly in states that are not politically aligned with disbursing federal governments. In contrast, protests are associated with decreased police violence against protesters in aligned states.

\footnotetext{
${ }^{30}$ Results from the labor union outcomes are presented in Appendix A.6.
} 


\subsection{State Expenditure}

In Section 2.2, we document that a major stated grievance among protesting public sector union workers is, and has historically been, non-payment of salaries. While there is no publicly available data on the details of state spending in Nigeria, evidence from the scholarly literature highlights that the major category for state recurrent expenditure is spending on salaries and personnel costs of public sector employees, while capital spending includes spending on new infrastructure like schools and health facilities (Asimiyu, Kizito et al., 2014). To test the hypothesis that protests may be higher in areas with more unpaid salaries of public sector workers, proxied by less state recurrent expenditure, we examine state expenditure outcomes in Table 8.

There is a significant negative association between protest intensity and state recurrent expenditures in the military period as shown in Panel A of Table 8. A one standard deviation increase in protest intensity is associated with a decrease in recurrent expenditure by $5 \%$ (column (1) of Panel A), and high protest intensity, using the indicator measure, is associated with a decrease in recurrent expenditure by $16 \%$ (column (3)). There is no significant association between protest intensity and capital expenditures in the military period. Panel B of Table 8 reports estimates of the links between protests and state expenditures in the democratic period. Protests, using the indicator measure, are negatively associated with recurrent expenditures (column (3)) of Panel B), with similar coefficient magnitudes to the military period (10.7\%). There is no significant difference in the association between protests and state expenditure by political alignment in the democratic period as shown in Panel C. The results from Table A9 in Appendix A.6 showing relatively higher labor union participation in protests, with no significant difference by political alignment, also provide suggestive evidence of the public sector worker grievance links with protests, in line with the reduced recurrent expenditure results. 


\section{Conclusion}

Can protests lead to meaningful changes in government policy, particularly around the redistribution of economic resources? We address this question and examine the effects of protests on fiscal redistribution using evidence from Nigeria over its military and democratic periods from 1988 to 2016. Nigeria's highly centralized fiscal system makes it an informative region to study government economic responses to protests in a heavily consolidatedtop-down revenue sharing system where government can choose to respond to ostensibly economic grievance-driven protests by directly disbursing fiscal resources.

We construct a new dataset from 26 years of archival records on public finance from 1988 to 2016 and test the predictions of a conceptual framework that federal governments with full control of revenue transfers to states will transfer more or less revenues to states in response to protests depending on the perceived marginal cost of effort on the part of state government leaders to quell protests that may be destabilizing to the federal government leader's tenure in office. The dataset provides an important addition to the sparse data landscape on subnational public financing, particularly in African countries. We provide evidence showing that federal governments respond to protests by increasing or decreasing revenue transfers to states. In line with the predictions of the framework, political party alignment, as a proxy for perceived cost of effort of state government leaders in quelling protests, can explain the heterogeneity in federal government responses to protests. Protests increase revenue transfers from disbursing federal governments to states only in states that are politically aligned with the federal government; protests reduce transfers to non-aligned states. Other conflict effects like battles are not associated with transfers, and protests have no effect on non-transfer revenue.

We use an instrumental variables strategy to examine how protests affect federal gov- 
ernment disbursement of transfers to protesting regions. We construct a new instrument that exploits the costs of coordination for protests during economic downturns to predict protest intensity. We find IV estimates consistent with our correlation results that federal governments respond to protests by redistributing fiscal transfers. We conduct a number of falsification tests for our instrument and demonstrate that our instrument only has predictive power for protests over periods with some threshold level of ICT mobile phone technology to facilitate easier communication for protest mobilization.

Given that responses to protests by governments are not only fiscal and can include increased violence against protesters, we examine the effects of protests on policing. We find suggestive evidence that protests increase policing and police violence against protesters, particularly in states that are not politically aligned with disbursing federal governments. In contrast, protests are associated with decreased police violence against protesters in aligned states. Lastly, we examine the association between protests and state expenditure and document significant negative associations between protests and recurrent expenditure, providing suggestive evidence for the grievance based claims of, in particular, protesting public sector workers around non-payment of salaries.

The results provide evidence that protests can influence fiscal redistribution. The ways in which they do this depends on the political relationships within governments and between disbursing federal governments and protesting regions. Governments can also respond to protests with increased state violence against protesters. Further research is needed to assess the links between protests and other economic redistribution like public good provision within states $^{31}$.

\footnotetext{
${ }^{31}$ We provide a brief blueprint for an exploration of this topic in Appendix A.7.
} 


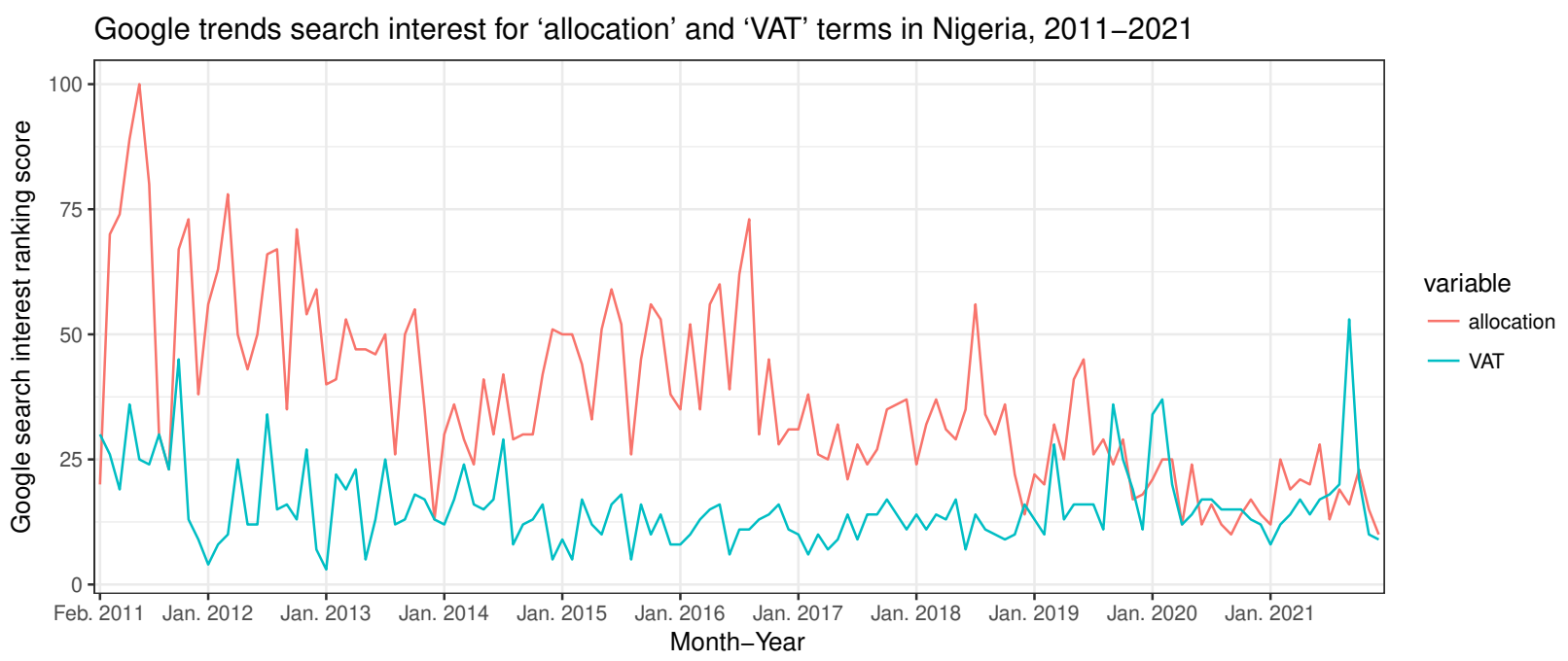

Figure 1: Google trends search interest ranking scores for 'allocation' and 'VAT' terms in Nigeria, 2011-2021

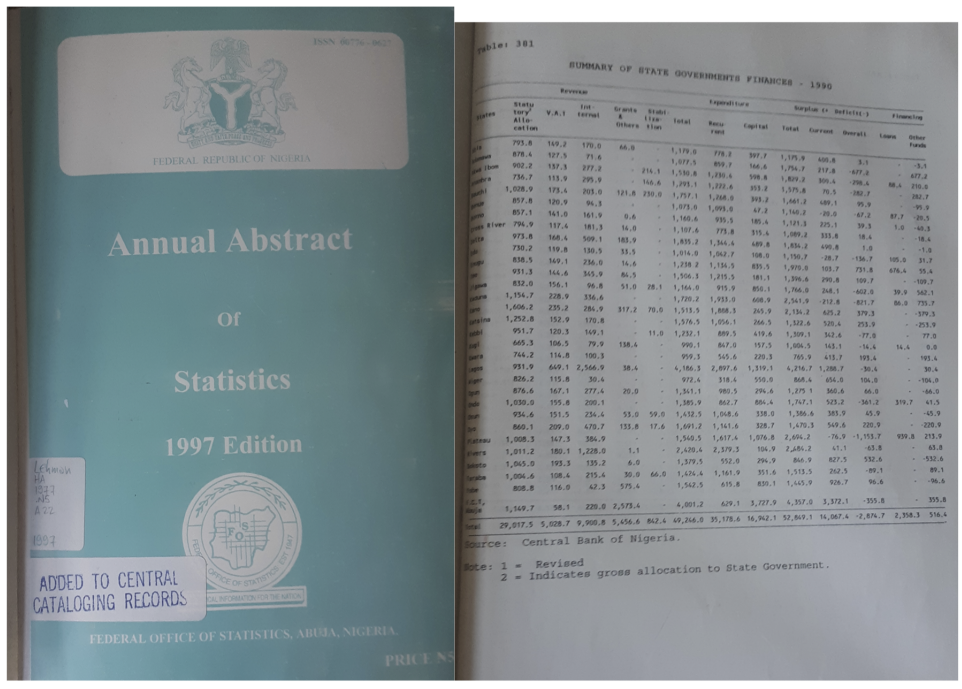

Figure 2: Example of archival data (1990) on public finance from the 1997 Annual Abstract of Statistics 

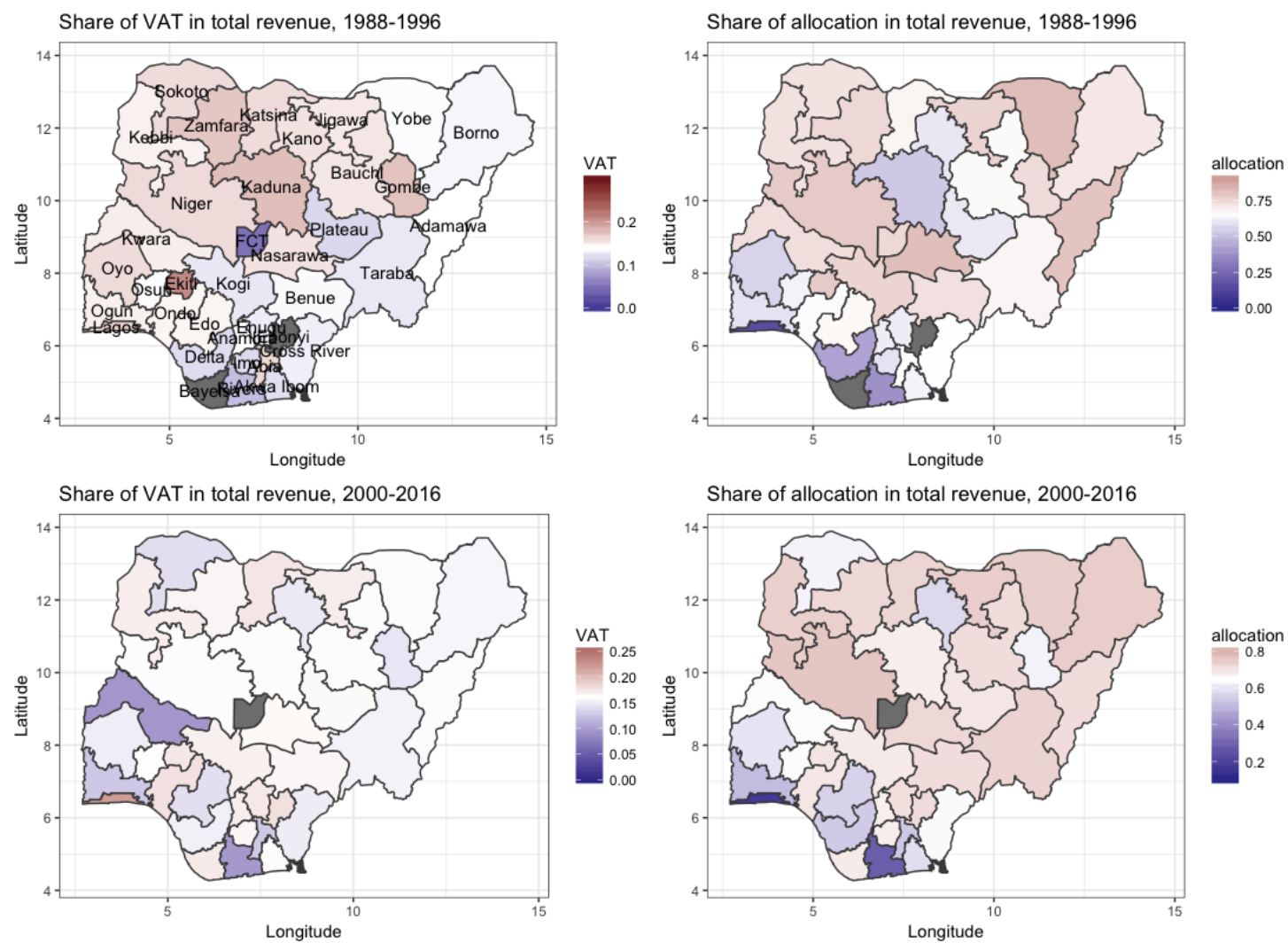

Figure 3: Share of intergovernmental transfers (VAT and Allocation) in total revenues in military (1988-1996) and democratic (2000-2016) periods
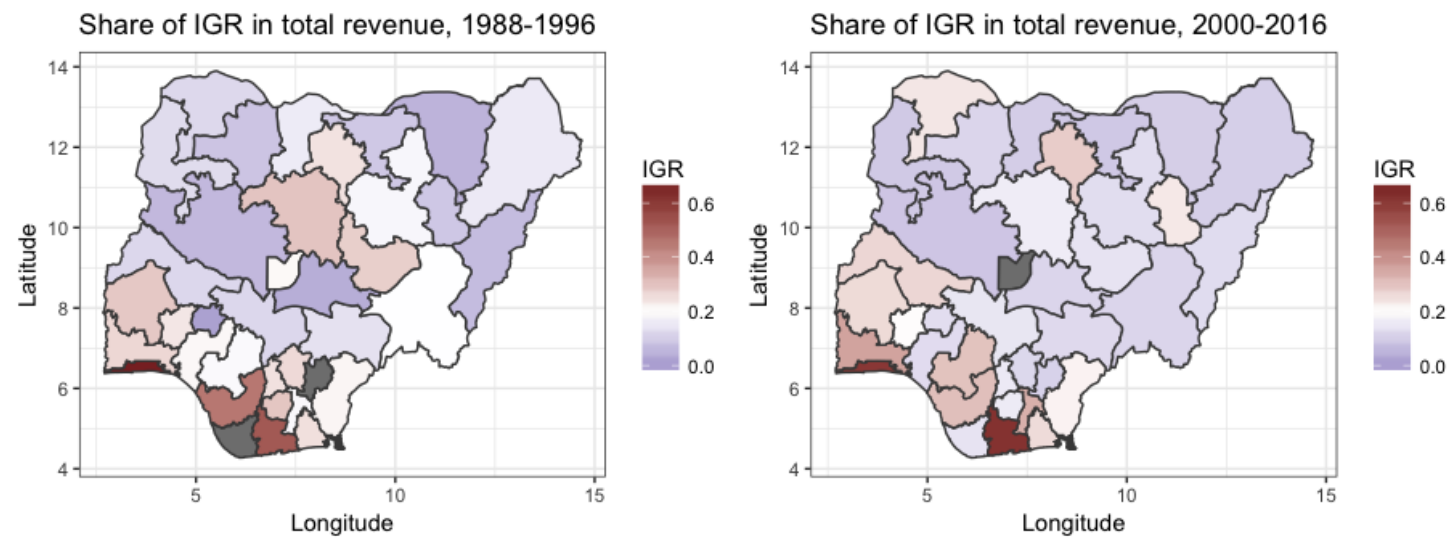

Figure 4: Share of internally generated revenue (IGR) in total revenues in military (19881996) and democratic (2000-2016) periods 

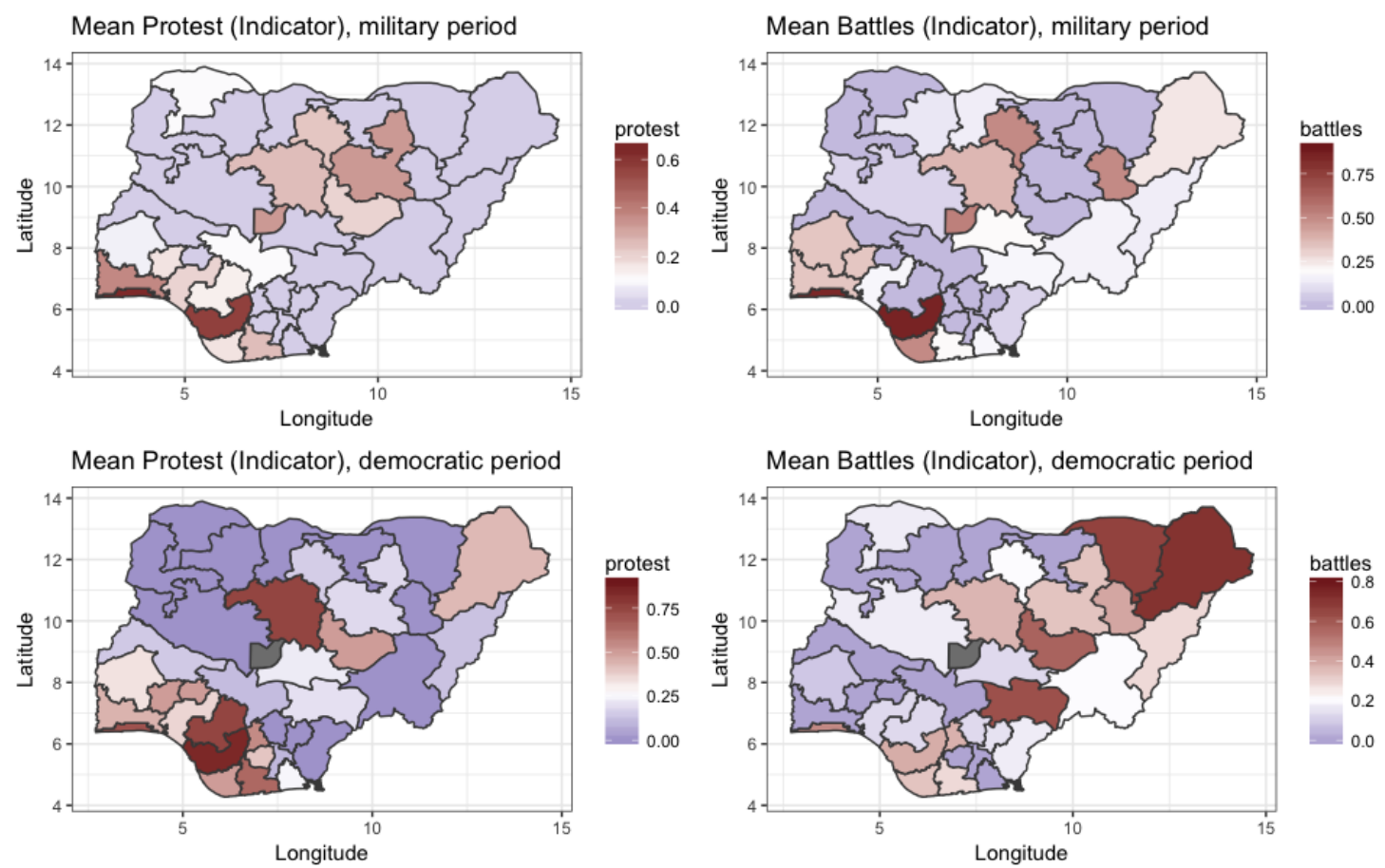

Figure 5: Mean protest and battles (indicator measure) in military period (1979-1999) and democratic period (2000-2016)

Likelihood of GP party match, 2000-2016

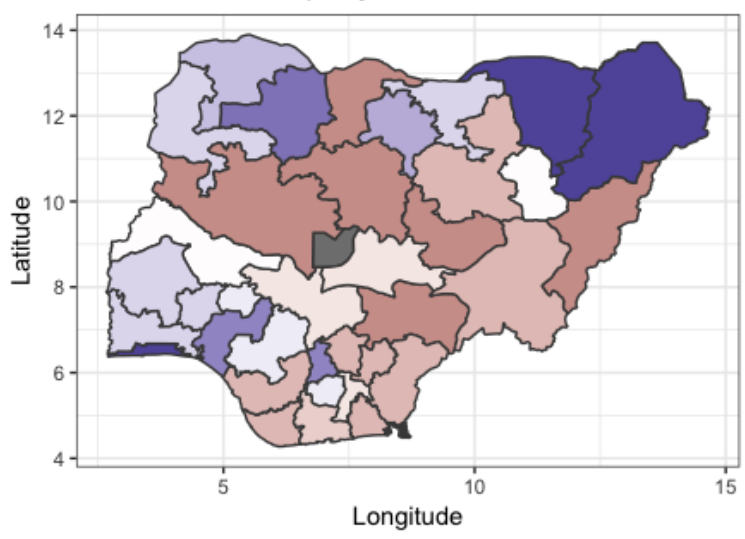

Share of states with governor-president (GP) party aligned

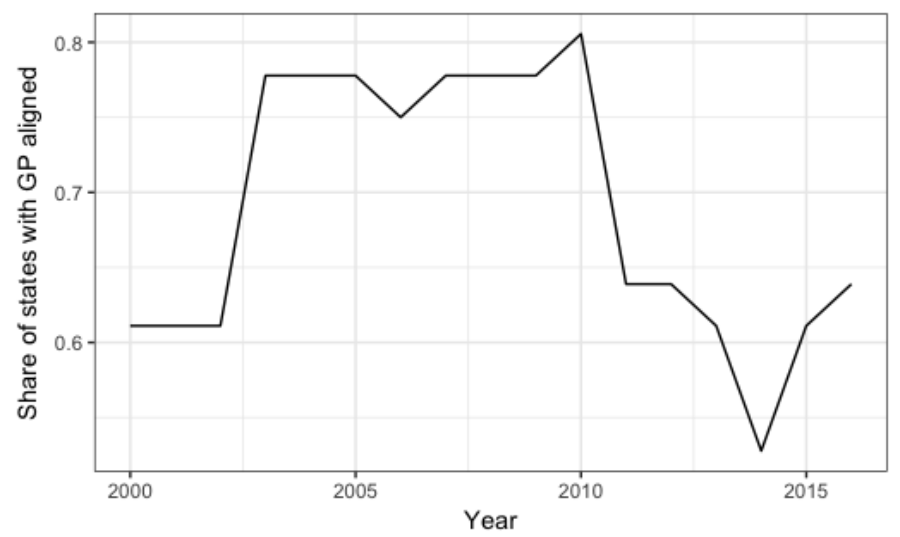

Figure 6: Likelihood of governor-president (GP) party alignment in the democratic period 
Table 1: OLS Estimates: Protest, other events and intergovernmental transfers (VAT, Allocation) and internally generated revenue (IGR), military period

\begin{tabular}{|c|c|c|c|c|c|c|}
\hline \multirow{4}{*}{$\begin{array}{l}\text { Covariate Measure: } \\
\text { Outcome: }\end{array}$} & \multicolumn{6}{|c|}{ Panel A: Protest and State Revenue Outcomes } \\
\hline & \multicolumn{3}{|c|}{ Protest (Continuous) } & \multicolumn{3}{|c|}{ Protest (Indicator) } \\
\hline & VAT & Allocation & IGR & VAT & Allocation & IGR \\
\hline & $(1)$ & $(2)$ & $(3)$ & $(4)$ & $(5)$ & (6) \\
\hline \multirow[t]{3}{*}{ Protest } & $0.052^{* * *}$ & $0.068^{* *}$ & -0.029 & $0.115^{*}$ & 0.172 & -0.210 \\
\hline & $(0.012)$ & $(0.031)$ & $(0.040)$ & $(0.061)$ & $(0.114)$ & $(0.129)$ \\
\hline & {$[0.005]$} & {$[0.201]$} & {$[0.609]$} & {$[0.306]$} & {$[0.271]$} & {$[0.211]$} \\
\hline Mean of outcome & 8.022 & 9.821 & 8.448 & 8.022 & 9.821 & 8.448 \\
\hline Observations & 61 & 101 & 86 & 61 & 101 & 86 \\
\hline \multirow[t]{2}{*}{ Clusters } & 31 & 35 & 33 & 31 & 35 & 33 \\
\hline & \multicolumn{6}{|c|}{$\begin{array}{c}\text { Panel B: Battles (Armed Conflict) and State Revenue Outcomes } \\
\text { Battles (Continuous) }\end{array}$} \\
\hline \multirow{2}{*}{$\begin{array}{l}\text { Covariate Measure: } \\
\text { Outcome: }\end{array}$} & VAT & Allocation & IGR & VAT & Allocation & IGR \\
\hline & (1) & $(2)$ & $(3)$ & $(4)$ & $(5)$ & $(6)$ \\
\hline \multirow[t]{3}{*}{ Battles } & -0.005 & $0.109^{*}$ & -0.032 & -0.027 & 0.136 & -0.113 \\
\hline & $(0.013)$ & $(0.058)$ & $(0.059)$ & $(0.031)$ & $(0.092)$ & $(0.088)$ \\
\hline & {$[0.716]$} & {$[0.243]$} & {$[0.641]$} & {$[0.442]$} & {$[0.203]$} & {$[0.296]$} \\
\hline Mean of outcome & 8.022 & 9.817 & 8.448 & 8.022 & 9.817 & 8.448 \\
\hline Observations & 73 & 132 & 106 & 73 & 132 & 106 \\
\hline Clusters & 32 & 35 & 33 & 32 & 35 & 33 \\
\hline
\end{tabular}

Covariate Measure:

Panel C: All Events and State Revenue Outcomes

Outcome:

All (Continuous)

\begin{tabular}{lcccccc} 
& $(1)$ & $(2)$ & $(3)$ & $(4)$ & $(5)$ & $(6)$ \\
\hline All Events & -0.018 & $0.223^{*}$ & 0.143 & 0.009 & 0.131 & $0.374^{* *}$ \\
& $(0.026)$ & $(0.114)$ & $(0.142)$ & $(0.031)$ & $(0.085)$ & $(0.163)$ \\
& {$[0.529]$} & {$[0.486]$} & {$[0.399]$} & {$[0.802]$} & {$[0.182]$} & {$[0.092]$} \\
Mean of outcome & & & & & & 8.282 \\
Observations & 8.073 & 9.842 & 8.282 & 8.073 & 9.842 & 170 \\
Clusters & 108 & 206 & 170 & 108 & 206 & 34 \\
\hline \hline District FE & 35 & 36 & 34 & 35 & 36 & Yes \\
Year FE & Yes & Yes & Yes & Yes & Yes & Yes \\
\hline \hline
\end{tabular}

Notes: Regressions estimated by OLS. Robust standard errors in parentheses clustered by district. Districts are administrative states in Nigeria. Wild cluster bootstrap (by district) p-values are in brackets. Dependent variables are intergovernmental transfers: log real VAT and state allocations, and log real internally generated revenue (IGR) at the state level as described in text. Protest is the continuous z-score measure of protests from the GDELT data in columns (1) to (3) and the indicator that equals one if the z-score is greater than 0 in columns (4) to (6) as described in text. Cooperation is defined similarly relative to the Z-score. ${ }^{* * *}$ Significant at the 1 percent level, ${ }^{* *}$ Significant at the 5 percent level, ${ }^{*}$ Significant at the 10 percent level. 
Table 2: OLS Estimates: Protest, other events and intergovernmental transfers (VAT, Allocation) and internally generated revenue (IGR), democratic period

\begin{tabular}{lcccccc}
\hline \hline & \multicolumn{5}{c}{ Panel A: Protest and State Revenue Outcomes } \\
Covariate Measure: & \multicolumn{5}{c}{ Protest (Continuous) } & Protest (Indicator) \\
Outcome: & VAT & Allocation & IGR & VAT & Allocation & IGR \\
& $(1)$ & $(2)$ & $(3)$ & $(4)$ & $(5)$ & $(6)$ \\
\hline Protest & $0.007^{*}$ & $-0.005^{* * *}$ & -0.026 & 0.002 & $-0.007^{* *}$ & -0.031 \\
& $(0.004)$ & $(0.002)$ & $(0.045)$ & $(0.009)$ & $(0.003)$ & $(0.083)$ \\
& {$[0.202]$} & {$[0.024]$} & {$[0.603]$} & {$[0.810]$} & {$[0.063]$} & {$[0.748]$} \\
Mean of outcome & 22.611 & 24.057 & 22.777 & 22.611 & 24.057 & 22.777 \\
Observations & 352 & 352 & 131 & 352 & 352 & 131 \\
Clusters & 36 & 36 & 36 & 36 & 36 & 36 \\
\hline
\end{tabular}

\begin{tabular}{|c|c|c|c|c|c|c|}
\hline \multirow{2}{*}{$\begin{array}{l}\text { Covariate Measure: } \\
\text { Outcome: }\end{array}$} & \multicolumn{6}{|c|}{ Panel B: Battles (Armed Conflict) and State Revenue Outcomes } \\
\hline & VAT & Allocation & IGR & VAT & Allocation & IGR \\
\hline & $(1)$ & $(2)$ & (3) & $(4)$ & $(5)$ & $(6)$ \\
\hline \multirow[t]{3}{*}{ Battles } & -0.007 & $0.003^{*}$ & -0.042 & -0.019 & $0.007^{*}$ & 0.044 \\
\hline & $(0.016)$ & $(0.002)$ & $(0.101)$ & $(0.022)$ & $(0.004)$ & $(0.164)$ \\
\hline & {$[0.825]$} & {$[0.109]$} & {$[0.737]$} & {$[0.633]$} & {$[0.102]$} & {$[0.796]$} \\
\hline Mean of outcome & 22.488 & 24.098 & 22.727 & 22.488 & 24.098 & 22.727 \\
\hline Observations & 283 & 283 & 116 & 283 & 283 & 116 \\
\hline \multirow[t]{2}{*}{ Clusters } & 36 & 36 & 36 & 36 & 36 & 36 \\
\hline & \multicolumn{6}{|c|}{ Panel C: All Conflict Events and State Revenue Outcomes } \\
\hline \multirow{3}{*}{$\begin{array}{l}\text { Covariate Measure: } \\
\text { Outcome: }\end{array}$} & \multicolumn{3}{|c|}{ All (Continuous) } & \multicolumn{3}{|c|}{ All (Indicator) } \\
\hline & VAT & Allocation & IGR & VAT & Allocation & IGR \\
\hline & $(1)$ & (2) & $(3)$ & $(4)$ & (5) & $(6)$ \\
\hline \multirow[t]{3}{*}{ All Events } & -0.005 & 0.002 & -0.041 & 0.006 & 0.005 & 0.078 \\
\hline & $(0.015)$ & $(0.001)$ & $(0.096)$ & $(0.006)$ & $(0.004)$ & $(0.143)$ \\
\hline & {$[0.867]$} & {$[0.253]$} & {$[0.778]$} & {$[0.272]$} & {$[0.238]$} & [0.633] \\
\hline Mean of outcome & 22.488 & 24.098 & 22.727 & 22.488 & 24.098 & 22.727 \\
\hline Observations & 352 & 352 & 131 & 352 & 352 & 131 \\
\hline Clusters & 36 & 36 & 36 & 36 & 36 & 36 \\
\hline District FE & Yes & Yes & Yes & Yes & Yes & Yes \\
\hline Year FE & Yes & Yes & Yes & Yes & Yes & Yes \\
\hline
\end{tabular}

Notes: Regressions estimated by OLS. Robust standard errors in parentheses clustered by district. Districts are administrative states in Nigeria. Wild cluster bootstrap (by district) p-values are in brackets. Dependent variables are intergovernmental transfers: log real VAT and state allocations, and log real internally generated revenue (IGR) at the state level as described in text. Protest is the continuous z-score measure of protests from the ACLED data in columns (1) to (3) and the indicator that equals one if the z-score is greater than 0 in columns (4) to (6) as described in text. Battles and All conflicts are defined similarly to protest. ${ }^{* * *}$ Significant at the 1 percent level, ${ }^{* *}$ Significant at the 5 percent level, ${ }^{*}$ Significant at the 10 percent level. 
Table 3: OLS Estimates: Protest, other events and intergovernmental transfers (VAT, Allocation) and internally generated revenue (IGR), democratic period by GP Aligned status

\begin{tabular}{|c|c|c|c|c|c|c|}
\hline \multirow{4}{*}{$\begin{array}{l}\text { Covariate Measure: } \\
\text { Outcome: }\end{array}$} & \multicolumn{6}{|c|}{ Panel A: Protest and State Revenue Outcomes } \\
\hline & \multicolumn{3}{|c|}{ Protest (Continuous) } & \multicolumn{3}{|c|}{ Protest (Indicator) } \\
\hline & VAT & Allocation & IGR & VAT & Allocation & IGR \\
\hline & $(1)$ & $(2)$ & $(3)$ & $(4)$ & (5) & $(6)$ \\
\hline \multirow[t]{3}{*}{ Protest } & $-0.011^{* *}$ & $-0.003^{* * *}$ & 0.011 & -0.028 & $-0.007^{* *}$ & 0.108 \\
\hline & $(0.005)$ & $(0.001)$ & $(0.060)$ & $(0.018)$ & $(0.004)$ & $(0.109)$ \\
\hline & {$[0.146]$} & {$[0.000]$} & {$[0.885]$} & {$[0.197]$} & {$[0.060]$} & {$[0.337]$} \\
\hline \multirow[t]{3}{*}{ Governor-President (GP) Aligned } & $0.044^{* * *}$ & -0.002 & -0.081 & $0.018^{* *}$ & -0.002 & 0.024 \\
\hline & $(0.011)$ & $(0.005)$ & $(0.229)$ & $(0.009)$ & $(0.005)$ & $(0.219)$ \\
\hline & {$[0.000]$} & {$[0.707]$} & {$[0.755]$} & {$[0.045]$} & [0.698] & {$[0.902]$} \\
\hline \multirow[t]{3}{*}{ Protest x GP Aligned } & $0.040^{* * *}$ & -0.004 & -0.079 & $0.066^{* *}$ & -0.0003 & -0.242 \\
\hline & $(0.010)$ & $(0.005)$ & $(0.108)$ & $(0.031)$ & $(0.007)$ & $(0.152)$ \\
\hline & {$[0.000]$} & {$[0.736]$} & {$[0.505]$} & {$[0.095]$} & {$[0.965]$} & {$[0.107]$} \\
\hline Mean of outcome & 22.488 & 24.098 & 22.727 & 22.488 & 24.098 & 22.727 \\
\hline Observations & 352 & 352 & 131 & 352 & 352 & 131 \\
\hline Clusters & 36 & 36 & 36 & 36 & 36 & 36 \\
\hline \multirow{3}{*}{$\begin{array}{l}\text { Covariate Measure: } \\
\text { Outcome: }\end{array}$} & \multicolumn{6}{|c|}{$\begin{array}{c}\text { Panel B: Battles (Armed Conflict) and State Revenue Outcomes } \\
\text { Battles (Continuous) }\end{array}$} \\
\hline & VAT & Allocation & IGR & VAT & Allocation & IGR \\
\hline & $(1)$ & $(2)$ & $(3)$ & $(4)$ & $(5)$ & $(6)$ \\
\hline \multirow[t]{3}{*}{ Battles } & -0.030 & 0.004 & -0.221 & -0.086 & 0.013 & 0.146 \\
\hline & $(0.034)$ & $(0.002)$ & $(0.227)$ & $(0.067)$ & $(0.009)$ & $(0.311)$ \\
\hline & {$[0.509]$} & {$[0.390]$} & {$[0.527]$} & {$[0.477]$} & {$[0.285]$} & {$[0.701]$} \\
\hline \multirow[t]{3}{*}{ Governor-President (GP) Aligned } & $0.050^{* * *}$ & -0.005 & 0.003 & $0.039^{* * *}$ & -0.005 & -0.106 \\
\hline & $(0.018)$ & $(0.006)$ & $(0.285)$ & $(0.013)$ & $(0.005)$ & $(0.219)$ \\
\hline & {$[0.032]$} & {$[0.406]$} & {$[0.999]$} & {$[0.006]$} & {$[0.375]$} & {$[0.684]$} \\
\hline \multirow[t]{3}{*}{ Battles x GP Aligned } & 0.033 & -0.0004 & 0.249 & 0.081 & -0.007 & -0.123 \\
\hline & $(0.034)$ & $(0.003)$ & $(0.259)$ & $(0.068)$ & $(0.010)$ & $(0.425)$ \\
\hline & {$[0.509]$} & {$[0.889]$} & {$[0.523]$} & {$[0.484]$} & {$[0.581]$} & {$[0.825]$} \\
\hline Mean of outcome & 22.488 & 24.098 & 22.727 & 22.488 & 24.098 & 22.727 \\
\hline Observations & 283 & 283 & 116 & 283 & 283 & 116 \\
\hline Clusters & 36 & 36 & 36 & 36 & 36 & 36 \\
\hline \multirow{3}{*}{$\begin{array}{l}\text { Covariate Measure: } \\
\text { Outcome: }\end{array}$} & \multicolumn{6}{|c|}{$\begin{array}{l}\text { Panel C: All Conflict Events and State Revenue Outcomes } \\
\text { All (Continuous) }\end{array}$} \\
\hline & VAT & Allocation & IGR & VAT & Allocation & IGR \\
\hline & $(1)$ & $(2)$ & $(3)$ & $(4)$ & $(5)$ & $(6)$ \\
\hline \multirow[t]{3}{*}{ All Events } & -0.034 & 0.003 & -0.230 & $-0.036^{*}$ & 0.007 & 0.185 \\
\hline & $(0.029)$ & $(0.002)$ & $(0.173)$ & $(0.019)$ & $(0.005)$ & $(0.127)$ \\
\hline & {$[0.523]$} & {$[0.336]$} & {$[0.557]$} & {$[0.102]$} & {$[0.223]$} & {$[0.231]$} \\
\hline \multirow[t]{3}{*}{ Governor-President (GP) Aligned } & $0.040^{* * *}$ & -0.001 & 0.049 & $0.019^{* *}$ & -0.0001 & -0.047 \\
\hline & $(0.013)$ & $(0.005)$ & $(0.246)$ & $(0.008)$ & $(0.005)$ & $(0.197)$ \\
\hline & {$[0.053]$} & {$[0.823]$} & {$[0.852]$} & {$[0.044]$} & {$[0.992]$} & {$[0.841]$} \\
\hline \multirow[t]{3}{*}{ All Events x GP Aligned } & 0.046 & -0.002 & 0.273 & $0.073^{* *}$ & -0.003 & -0.160 \\
\hline & $(0.032)$ & $(0.004)$ & $(0.197)$ & $(0.034)$ & $(0.007)$ & $(0.254)$ \\
\hline & {$[0.523]$} & {$[0.605]$} & {$[0.435]$} & {$[0.083]$} & {$[0.686]$} & {$[0.586]$} \\
\hline Mean of outcome & 22.488 & 24.098 & 22.727 & 22.488 & 24.098 & 22.727 \\
\hline Observations & 352 & 352 & 131 & 352 & 352 & 131 \\
\hline Clusters & 36 & 36 & 36 & 36 & 36 & 36 \\
\hline District FE & Yes & Yes & Yes & Yes & Yes & Yes \\
\hline Year FE & Yes & Yes & Yes & Yes & Yes & Yes \\
\hline
\end{tabular}


Table 4: Instrument validity and falsification tests: Links between protest, other events and ethnolinguistic similarity interacted with negative economic shocks instrument

\begin{tabular}{lcccc}
\hline \hline \multirow{2}{*}{ Outcome: } & \multicolumn{3}{c}{ Panel A: Democratic Period } \\
& Protest & \multicolumn{2}{c}{ Battles } \\
& Continuous & Indicator & Continuous & Indicator \\
& $(1)$ & $(2)$ & $(3)$ & $(4)$ \\
\hline Ethnolinguistic Similarity & & & & \\
x Negative Shock Year & $2.963^{* * *}$ & $1.262^{* * *}$ & -3.710 & $-0.826^{* *}$ \\
& $(0.594)$ & $(0.413)$ & $(2.518)$ & $(0.383)$ \\
& {$[0.000]$} & {$[0.003]$} & {$[0.377]$} & {$[0.064]$} \\
Mean of outcome & -0.045 & 0.310 & 0.073 & 0.258 \\
Observations & 352 & 352 & 283 & 283 \\
Clusters & 36 & 36 & 36 & 36 \\
\hline
\end{tabular}

Outcome:

Protest

Panel B: Military Period

Battles

Continuous Indicator Continuous Indicator

(1)

(2)

(3)

(4)

Ethnolinguistic Similarity

x Negative Shock Year

0.265

(0.542)

[0.634]

0.369

(0.331)

[0.269]

$-2.055^{* * *}$
$(0.552)$
$[0.000]$

$-1.184^{* * *}$

$(0.314)$

[0.000]

\begin{tabular}{lcccc} 
Mean of outcome & 0.009 & 0.144 & 0.003 & 0.233 \\
Observations & 264 & 264 & 326 & 326 \\
Clusters & 37 & 37 & 37 & 37 \\
\hline \hline District FE & Yes & Yes & Yes & Yes \\
Year FE & Yes & Yes & Yes & Yes \\
\hline \hline
\end{tabular}

Notes: Regressions estimated by OLS. Robust standard errors in parentheses clustered by district. Districts are administrative states in Nigeria. Wild cluster bootstrap (by district) p-values are in brackets. Dependent variables are Protest and Battles, with both described as the continuous z-score measure in columns (1) to (3) and the indicator that equals one if the $\mathrm{z}$-score is greater than 0 in columns (2) to (4) as described in text. ${ }^{* * *}$ Significant at the 1 percent level, ${ }^{* *}$ Significant at the 5 percent level, ${ }^{*}$ Significant at the 10 percent level. 
Table 5: IV estimates of the effect of protests on intergovernmental transfers using the ethnolinguistic similarity interacted with negative economic shocks instrument, and comparison OLS estimates, democratic period

\section{Outcome:}

Ethnolinguistic Similarity

$\mathrm{x}$ Negative Shock Year

F-Stat of Excluded Instrument

Governor-President (GP) Aligned

Mean of outcome

Observations

Clusters

\section{ne}

Aligned

No
-0.045
352
36

$2.963^{* * *}$
$(0.653)$

Panel A: First-Stage Estimates Protest (Continuous)

(1) (2)

20.61

$2.880^{* * *}$
$(0.752)$

14.65

Yes
-0.045
352
36

(3)

$2.963^{* * *}$
$(0.653)$

20.61

No
-0.045
352
36

36
(4)

$$
2.880^{* * *}
$$

14.65

Panel B: Second-Stage 2SLS Estimates

Outcome: VAT Allocation

\begin{tabular}{lcccc} 
& $(1)$ & $(2)$ & $(3)$ & $(4)$ \\
\hline Protest & -0.014 & 0.003 & $-0.021^{* * *}$ & $-0.024^{* * *}$ \\
& $(0.012)$ & $(0.014)$ & $(0.007)$ & $(0.007)$ \\
Governor-President (GP) Aligned & No & Yes & No & Yes \\
Mean of outcome & 22.488 & 22.488 & 24.098 & 24.098 \\
Observations & 352 & 352 & 352 & 352 \\
Clusters & 36 & 36 & 36 & 36 \\
\hline
\end{tabular}

\section{Outcome:}

\section{Panel C: OLS Estimates}

\begin{tabular}{lcccc} 
& $(1)$ & $(2)$ & $(3)$ & $(4)$ \\
\hline Protest & $0.007^{*}$ & $0.009^{* *}$ & $-0.005^{* * *}$ & $-0.005^{* * *}$ \\
& $(0.004)$ & $(0.004)$ & $(0.002)$ & $(0.002)$ \\
Governor-President (GP) Aligned & No & Yes & No & Yes \\
Mean of outcome & 22.488 & 22.488 & 24.098 & 24.098 \\
Observations & 352 & 352 & 352 & 352 \\
Clusters & 36 & 36 & 36 & 36 \\
\hline \hline District FE & Yes & Yes & Yes & Yes \\
Year FE & Yes & Yes & Yes & Yes \\
\hline \hline
\end{tabular}

Notes: Robust standard errors in parentheses clustered by district. Districts are administrative states in Nigeria. District and year fixed effects are included in all regressions. Dependent variable in Panel A is Protest. Protest is the continuous z-score measure of protests from the ACLED data as described in text. Ethnolinguistic Similarity x Negative Shock Year is the interacted instrument which interacts the degree of ethnolinguistic similarity at the state level with the share of states experiencing negative economic shocks in a year as defined in the text. Dependent variables in Panel $\mathrm{B}$ and Panel $\mathrm{C}$ are intergovernmental transfers: log real VAT and state allocati 1 As at the state level. *** Significant at the 1 percent level, ** Significant at the 5 percent level, * Significant at the 10 percent level. 

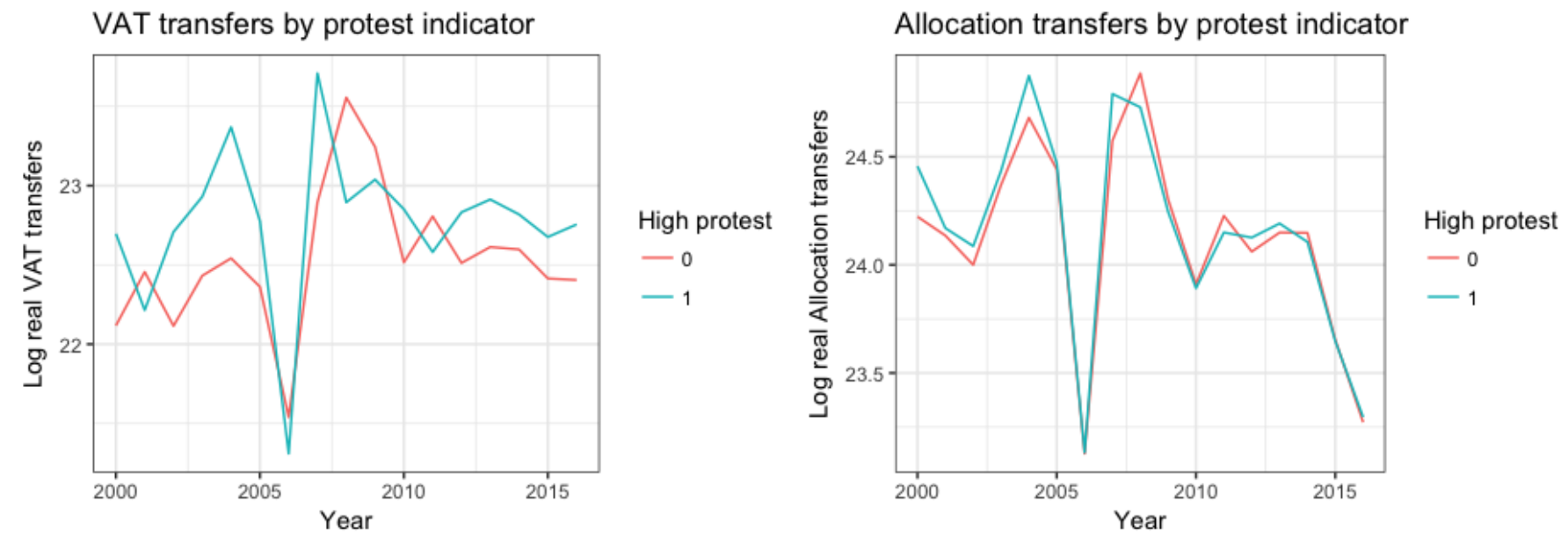

Figure 7: Average VAT and Allocation transfers by protest intensity (indicator). Higher variance in VAT transfers than allocation transfers in relatively high vs low protest areas

Table 6: Reduced form estimates for the ethnolinguistic similarity interacted with negative economic shock year instrument and intergovernmental transfers, democratic period

\begin{tabular}{|c|c|c|c|c|c|c|}
\hline \multirow[t]{2}{*}{ Outcome: } & \multicolumn{3}{|c|}{ VAT } & \multicolumn{3}{|c|}{ Allocation } \\
\hline & $(1)$ & $(2)$ & $(3)$ & $(4)$ & $(5)$ & $(6)$ \\
\hline \multicolumn{7}{|l|}{ Ethnolinguistic Similarity } \\
\hline x Negative Shock Year (ESN) & $\begin{array}{r}-0.050 \\
(0.034) \\
{[0.150]}\end{array}$ & $\begin{array}{r}-0.027 \\
(0.035) \\
{[0.438]}\end{array}$ & $\begin{array}{r}-0.032 \\
(0.038) \\
{[0.403]}\end{array}$ & $\begin{array}{c}-0.045^{* *} \\
(0.022) \\
{[0.054]}\end{array}$ & $\begin{array}{c}-0.047^{* *} \\
(0.022) \\
{[0.031]}\end{array}$ & $\begin{array}{r}-0.030 \\
(0.023) \\
{[0.205]}\end{array}$ \\
\hline Governor-President (GP) Aligned & & $\begin{array}{c}0.020^{* *} \\
(0.010) \\
{[0.043]}\end{array}$ & $\begin{array}{c}0.021^{*} \\
(0.013) \\
{[0.098]}\end{array}$ & & $\begin{array}{r}-0.001 \\
(0.005) \\
{[0.765]}\end{array}$ & $\begin{array}{r}-0.004 \\
(0.006) \\
{[0.492]}\end{array}$ \\
\hline ESN x GP Aligned & & & $\begin{array}{c}0.006 \\
(0.041) \\
{[0.870]}\end{array}$ & & & $\begin{array}{r}-0.024 \\
(0.017) \\
{[0.160]}\end{array}$ \\
\hline Mean of outcome & 22.488 & 22.488 & 22.488 & 24.098 & 24.098 & 24.098 \\
\hline Observations & 612 & 612 & 612 & 612 & 612 & 612 \\
\hline Clusters & 36 & 36 & 36 & 36 & 36 & 36 \\
\hline District FE & Yes & Yes & Yes & Yes & Yes & Yes \\
\hline Year FE & Yes & Yes & Yes & Yes & Yes & Yes \\
\hline
\end{tabular}

Notes: Regressions estimated by OLS. Robust standard errors in parentheses clustered by district. Districts are administrative states in Nigeria. Wild cluster bootstrap (by district) p-values are in brackets. Dependent variables are intergovernmental transfers: log real VAT and state allocations at the state level as described in text. Protest is the continuous z-score measure of protests from the ACLED data as described in text. ${ }^{* * *}$ Significant at the 1 percent level, ${ }^{* *}$ Significant at the 5 percent level, *Significant at the 10 percent level. 
Table 7: OLS Estimates: Protest and policing, share of other major actors in events, democratic period

\begin{tabular}{|c|c|c|c|c|c|c|}
\hline \multirow[t]{2}{*}{ Outcome: } & \multicolumn{6}{|c|}{$\begin{array}{c}\text { Panel A: Protest Events Sample } \\
\text { Military Share }\end{array}$} \\
\hline & $(1)$ & $(2)$ & $(3)$ & $(4)$ & $(5)$ & $(6)$ \\
\hline Protest & $\begin{array}{c}0.026^{* *} \\
(0.012) \\
{[0.080]}\end{array}$ & $\begin{array}{l}0.049^{* * *} \\
(0.013) \\
{[0.000]}\end{array}$ & $\begin{array}{r}-0.002 \\
(0.009) \\
{[0.813]}\end{array}$ & $\begin{array}{c}-0.005 \\
(0.012) \\
{[0.662]}\end{array}$ & $\begin{array}{c}0.014^{*} \\
(0.008) \\
{[0.156]}\end{array}$ & $\begin{array}{c}0.024^{* *} \\
(0.012) \\
{[0.222]}\end{array}$ \\
\hline Governor-President (GP) Aligned & & $\begin{array}{c}-0.026 \\
(0.027) \\
{[0.368]}\end{array}$ & & $\begin{array}{c}-0.001 \\
(0.015) \\
{[0.953]}\end{array}$ & & $\begin{array}{c}-0.019 \\
(0.017) \\
{[0.332]}\end{array}$ \\
\hline Protest x GP Aligned & & $\begin{array}{c}-0.046^{* *} \\
(0.018) \\
{[0.000]}\end{array}$ & & $\begin{array}{c}0.005 \\
(0.009) \\
{[0.629]}\end{array}$ & & $\begin{array}{r}-0.021 \\
(0.013) \\
{[0.180]}\end{array}$ \\
\hline Mean of outcome & 0.151 & 0.151 & 0.026 & 0.026 & 0.074 & 0.074 \\
\hline Observations & 352 & 352 & 352 & 352 & 352 & 352 \\
\hline Clusters & 36 & 36 & 36 & 36 & 36 & 36 \\
\hline
\end{tabular}

\begin{tabular}{lcccccc}
\hline \multirow{2}{*}{ Outcome: } & \multicolumn{2}{c}{ Police Share } & \multicolumn{3}{c}{ Panel B: Battles Events Sample } & \multicolumn{2}{c}{ Party Share } \\
& $(1)$ & $(2)$ & $(3)$ & $(4)$ & $(5)$ & $(6)$ \\
\hline Battles & -0.027 & -0.005 & $0.066^{* * *}$ & $0.052^{* *}$ & $-0.043^{* * *}$ & $-0.048^{* * *}$ \\
& $(0.019)$ & $(0.031)$ & $(0.021)$ & $(0.024)$ & $(0.012)$ & $(0.013)$ \\
& {$[0.391]$} & {$[0.871]$} & {$[0.073]$} & {$[0.284]$} & {$[0.000]$} & {$[0.000]$} \\
Governor-President (GP) Aligned & & 0.054 & & $0.063^{*}$ & & $-0.084^{*}$ \\
& & $(0.043)$ & & $(0.037)$ & $(0.050)$ \\
Battles x GP Aligned & & {$[0.252]$} & & {$[0.089]$} & {$[0.139]$} \\
& & $-0.040^{*}$ & & 0.017 & 0.016 \\
& & $(0.024)$ & & $(0.022)$ & & $(0.015)$ \\
Mean of outcome & & & & & $0.128]$ \\
Observations & & & & $0.530]$ & 0.132 \\
Clusters & 0.348 & 0.348 & 0.216 & 0.216 & 0.132 & 0.132 \\
\hline \hline District FE & 283 & 283 & 283 & 283 & 283 & 283 \\
Year FE & 36 & 36 & 36 & 36 & 36 & 36 \\
\hline \hline
\end{tabular}

Notes: Regressions estimated by OLS. Robust standard errors in parentheses clustered by district. Districts are administrative states in Nigeria. Wild cluster bootstrap (by district) p-values are in brackets. Dependent variables are shares of police, military or political party actors in all protest events and in all battles events in each state in Panel A and Panel B respectively over 2000 to 2016 years of available data as described in text. Protest is the continuous z-score measure of protests from the ACLED data as described in text. Battles are defined similarly relative to the z-score. ${ }^{* * *}$ Significant at the 1 percent level, ${ }^{* *}$ Significant at the 5 percent level, ${ }^{*}$ Significant at the 10 percent level. 
Table 8: OLS Estimates: Protest and state recurrent and capital expenditures

\begin{tabular}{lcccc}
\hline \hline & \multicolumn{3}{c}{$\begin{array}{c}\text { Panel A: Protest and State Expenditure, Military Period } \\
\text { Protest (Indicator) }\end{array}$} \\
$\begin{array}{l}\text { Covariate Measure: } \\
\text { Outcome: }\end{array}$ & $\begin{array}{c}\text { Protest (Continuous) } \\
\text { Recurrent }\end{array}$ & CapEx & Recurrent & $(4)$ \\
& $(1)$ & $(2)$ & $(3)$ & 0.019 \\
\hline Protest & $-0.050^{* * *}$ & 0.032 & $-0.161^{* * *}$ & $(0.222)$ \\
& $(0.019)$ & $(0.058)$ & $(0.046)$ & {$[0.930]$} \\
Mean of outcome & {$[0.015]$} & {$[0.620]$} & {$[0.000]$} & 9.160 \\
Observations & 9.929 & 9.160 & 9.929 & 88 \\
Clusters & 88 & 88 & 88 & 34 \\
\hline
\end{tabular}

\begin{tabular}{lcccc}
\hline & \multicolumn{3}{c}{$\begin{array}{c}\text { Panel B: Protest and State Expenditure, Democratic Period } \\
\text { Covariate Measure: }\end{array}$} & $\begin{array}{c}\text { Protest (Indicator) } \\
\text { Protest (Continuous) } \\
\text { Outcome: }\end{array}$ \\
& Recurrent & CapEx & Recurrent & $(4)$ \\
& $(1)$ & $(2)$ & $(3)$ & -0.038 \\
& -0.023 & -0.102 & $-0.107^{*}$ & $(0.983)$ \\
Protest & $(0.028)$ & $(0.372)$ & $(0.057)$ & {$[0.932]$} \\
& {$[0.446]$} & {$[0.721]$} & {$[0.077]$} & 23.635 \\
Mean of outcome & 24.416 & 23.635 & 24.416 & 131 \\
Observations & 131 & 131 & 131 & 36
\end{tabular}

\begin{tabular}{lcccc}
\hline & \multicolumn{2}{c}{$\begin{array}{c}\text { Panel C: Protest and State Expenditure, Democratic Period [by GP Alic } \\
\text { Protest (Continuous) }\end{array}$} & & $\begin{array}{c}\text { Protest (Indicator) } \\
\text { Povariate Measure: }\end{array}$ \\
Outcome: & Recurrent & CapEx & Recurrent & $(4)$ \\
& $(1)$ & $(2)$ & $(3)$ & -1.770 \\
& 0.002 & -0.742 & -0.067 & $(2.123)$ \\
Protest & $(0.020)$ & $(0.765)$ & $(0.071)$ & {$[0.709]$} \\
& {$[0.892]$} & {$[0.435]$} & {$[0.381]$} & -0.143 \\
Governor-President (GP) Aligned & -0.094 & 1.344 & -0.074 & $(0.545)$ \\
& $(0.101)$ & $(1.232)$ & $(0.088)$ & {$[0.759]$} \\
Protest x GP Aligned & {$[0.399]$} & {$[0.430]$} & {$[0.462]$} & 3.044 \\
& -0.056 & 1.383 & -0.087 & $(2.727)$ \\
& $(0.105)$ & $(2.727)$ & $(0.105)$ & {$[0.397]$} \\
Mean of outcome & {$[0.390]$} & {$[0.352]$} & {$[0.452]$} & 23.635 \\
Observations & & & \\
Clusters & 24.416 & 23.635 & 24.416 & 131 \\
\hline \hline District FE & 131 & 131 & 36 & 36 \\
Year FE & 36 & 36 & Yes & Yes \\
\hline \hline
\end{tabular}

Notes: Regressions estimated by OLS. Robust standard errors in parentheses clustered by district. Districts are administrative states in Nigeria. Wild cluster bootstrap (by district) p-values are in brackets. Dependent variables are expenditures, namely recurrent expenditures and capital expenditures (CapEx) at the state level as described in text. Protest is the continuous z-score measure of protests in columns (1) to (2) and the indicator that equals one if the $\mathrm{z}$-score is greater than 0 in columns (3) to (4) as described in text. ${ }^{* * *}$ Significant at the 1 percent level, ${ }^{* *}$ Significant at the 5 percent level, *Significant at the 10 percent level. 


\section{References}

Acemoglu, Daron, Tarek A Hassan, and Ahmed Tahoun. 2018. "The power of the street: Evidence from Egypt's Arab Spring." The Review of Financial Studies 31 (1): 1-42.

Adeloye, Davies, Rotimi Adedeji David, Adenike Ayobola Olaogun, Asa Auta, Adedapo Adesokan, Muktar Gadanya, Jacob Kehinde Opele, Oluwafemi Owagbemi, and Alexander Iseolorunkanmi. 2017. "Health workforce and governance: the crisis in Nigeria." Human resources for health 15 (1): 1-8.

Akanle, Olayinka, Kudus Adebayo, and Olorunlana Adetayo. 2014. "Fuel subsidy in Nigeria: contexts of governance and social protest." International Journal of Sociology and Social Policy .

Akuul, Timbee. 2011. "The role of the Nigerian Police Force in maintaining peace and security in Nigeria." Journal of Social Science and Public Policy 3 (7): 16-23.

Alm, James, Betty R Jackson, and Michael McKee. 1992. "Estimating the determinants of taxpayer compliance with experimental data." National Tax Journal pp. 107-114.

Alm, James, and Jameson Boex. 2008. "The role of economic versus political factors in the incidence of intergovernmental transfers in Nigeria." The Journal of Developing Areas pp. $1-19$.

Andreoni, James, Brian Erard, and Jonathan Feinstein. 1998. "Tax compliance." Journal of economic literature $36(2)$ : 818-860.

Angrist, Joshua D, and Alan B Krueger. 2001. "Instrumental variables and the search for identification: From supply and demand to natural experiments." Journal of Economic perspectives 15 (4): 69-85. 
Archibong, Belinda. 2019. "Explaining divergence in the long-term effects of precolonial centralization on access to public infrastructure services in Nigeria." World Development 121: $123-140$.

Archibong, Belinda, Brahima S Coulibaly, and Ngozi Okonjo-Iweala. 2021. "Washington consensus reforms and lessons for economic performance in Sub-Saharan Africa." Journal of Economic Perspectives 35 (3): 133-156.

Archibong, Belinda, and Nonso Obikili. 2020. "Prison labor: The price of prisons and the lasting effects of incarceration." African Economic History Working Paper Series (52).

Asimiyu, Abiola G, Ehigiamusoe Uyi Kizito et al. 2014. "Analysis of internally generated revenue and its implications On fiscal viability of State Governments in Nigeria." Journal of empirical economics 2 (4): 216-228.

Azeez, Ademola. 2009. "Ethnicity, Party Politics and Democracy in Nigeria: Peoples Democratic Party (PDP) as Agent of Consolidation?" Studies of Tribes and Tribals 7 (1): 1-9.

Banful, Afua Branoah. 2011. "Do formula-based intergovernmental transfer mechanisms eliminate politically motivated targeting? Evidence from Ghana." Journal of Development Economics 96 (2): 380-390.

Battaglini, Marco. 2017. "Public protests and policy making." The Quarterly Journal of Economics 132 (1): 485-549.

Bellemare, Marc F. 2015. "Rising food prices, food price volatility, and social unrest." American Journal of Agricultural Economics 97 (1): 1-21.

Boadway, Robin W, and Anwar Shah. 2007. Intergovernmental fiscal transfers: principles and practices. World Bank Publications. 
Branch, Adam, and Zachariah Mampilly. 2015. Africa uprising: Popular protest and political change. Zed Books Ltd.

Bratton, Michael, and Nicolas Van de Walle. 1992. "Popular protest and political reform in Africa." Comparative politics pp. 419-442.

Buchanan, James M. 1950. "Federalism and fiscal equity." The American Economic Review $40(4): 583-599$.

Cantoni, Davide, David Y Yang, Noam Yuchtman, and Y Jane Zhang. 2019. "Protests as strategic games: experimental evidence from Hong Kong's antiauthoritarian movement." The Quarterly Journal of Economics 134 (2): 1021-1077.

Casey, Katherine. 2015. "Crossing party lines: The effects of information on redistributive politics." American Economic Review 105 (8): 2410-48.

Collins, William J, and Robert A Margo. 2007. "The economic aftermath of the 1960s riots in American cities: Evidence from property values." The Journal of Economic History 67 (4): 849-883.

Cox, Gary W, and Mathew D McCubbins. 1986. "Electoral politics as a redistributive game." The Journal of Politics 48 (2): 370-389.

Cullen, Julie Berry, Nicholas Turner, and Ebonya L Washington. 2019. "Political alignment, attitudes toward government and tax evasion." Forthcoming in American Economic Journal: Economic Policy .

Ekpo, Akpan H. 1994. "Fiscal federalism: Nigeria's post-independence experience, 1960-90." World Development 22 (8): 1129-1146.

El-Mallakh, Nelly. 2020. "How do protests affect electoral choices? Evidence from Egypt." Journal of Economic Behavior \& Organization 179: 299-322. 
El-Mallakh, Nelly, Mathilde Maurel, and Biagio Speciale. 2018. "Arab spring protests and women's labor market outcomes: Evidence from the Egyptian revolution." Journal of Comparative Economics 46 (2): 656-682.

Ellman, Matthew, and Leonard Wantchekon. 2000. "Electoral competition under the threat of political unrest." The Quarterly journal of economics 115 (2): 499-531.

Enikolopov, Ruben, Alexey Makarin, and Maria Petrova. 2020. "Social media and protest participation: Evidence from Russia." Econometrica 88 (4): 1479-1514.

Fiva, Jon H, and Askill H Halse. 2016. "Local favoritism in at-large proportional representation systems." Journal of Public Economics 143: 15-26.

Frey, Bruno S, and Benno Torgler. 2007. "Tax morale and conditional cooperation." Journal of comparative economics 35 (1): 136-159.

Frynas, Jedrzej George. 2001. "Corporate and state responses to anti-oil protests in the Niger Delta." African Affairs 100 (398): 27-54.

Gershman, Boris, and Diego Rivera. 2018. "Subnational diversity in Sub-Saharan Africa: Insights from a new dataset." Journal of Development Economics 133: 231-263.

González, Felipe. 2020. "Collective action in networks: Evidence from the Chilean student movement." Journal of Public Economics 188: 104220.

Hodler, Roland, and Paul A Raschky. 2014. "Regional favoritism." The Quarterly Journal of Economics 129 (2): 995-1033.

Hollyer, James R, B Peter Rosendorff, and James Raymond Vreeland. 2015. "Transparency, protest, and autocratic instability." American Political Science Review pp. 764-784. 
Luttmer, Erzo FP, and Monica Singhal. 2014. "Tax morale." Journal of Economic Perspectives 28 (4): 149-68.

Madestam, Andreas, Daniel Shoag, Stan Veuger, and David Yanagizawa-Drott. 2013. "Do political protests matter? evidence from the tea party movement." The Quarterly Journal of Economics 128 (4): 1633-1685.

Manacorda, Marco, and Andrea Tesei. 2020. "Liberation technology: Mobile phones and political mobilization in Africa." Econometrica 88 (2): 533-567.

Maystadt, Jean-François, and Muhammad-Kabir Salihu. 2019. "National or political cake? The political economy of intergovernmental transfers in Nigeria." Journal of Economic Geography 19 (5): 1119-1142.

Mazumder, Soumyajit. 2018. "The persistent effect of US civil rights protests on political attitudes." American Journal of Political Science 62 (4): 922-935.

McCulloch, NEIL, Tom Moerenhout, and Joonseok Yang. 2020. "Building a Social Contract? Understanding Tax Morale in Nigeria." The Journal of Development Studies pp. 1-18.

Montalvo, José G, and Marta Reynal-Querol. 2005. "Ethnic polarization, potential conflict, and civil wars." American economic review 95 (3): 796-816.

Musgrave, Richard A. 1997. "Devolution, grants, and fiscal competition." Journal of Economic perspectives 11 (4): 65-72.

Nunn, Nathan, and Leonard Wantchekon. 2011. "The slave trade and the origins of mistrust in Africa." American Economic Review 101 (7): 3221-52.

Oates, Wallace E. 1993. "Fiscal decentralization and economic development." National tax journal 46 (2): 237-243. 
Oates, Wallace E. 1999. "An essay on fiscal federalism." Journal of economic literature 37 (3): 1120-1149.

Okauru, Ifueko Omoigui. 2012. Comprehensive Tax History of Nigeria. African Books Collective.

Omotola, J Shola. 2009. “'Garrison’ democracy in Nigeria: The 2007 general elections and the prospects of democratic consolidation." Commonwealth \& Comparative Politics 47 (2): $194-220$.

Onuigbo, Richard Amaechi, and Eme Okechukwu Innocent. 2015. "State governors and revenue allocation formula in Nigeria: A case of the fourth republic." International Journal of Accounting Research 42 (2437): 1-23.

Osaghae, Eghosa E. 1995. "The Ogoni uprising: oil politics, minority agitation and the future of the Nigerian state." African affairs 94 (376): 325-344.

Owen, Olly, and Zainab Usman. 2015. "Briefing: Why Goodluck Jonathan lost the Nigerian presidential election of 2015." African Affairs 114 (456): 455-471.

Poterba, James M. 1994. "State responses to fiscal crises: The effects of budgetary institutions and politics." Journal of political Economy 102 (4): 799-821.

Raleigh, Clionadh, Andrew Linke, Håvard Hegre, and Joakim Karlsen. 2010. "Introducing ACLED: an armed conflict location and event dataset: special data feature." Journal of peace research 47 (5): 651-660.

Salami, Adeleke. 2011. "Taxation, revenue allocation and fiscal federalism in Nigeria: Issues, challenges and policy options." Economic annals 56 (189): 27-50.

Sender, John. 1999. "Africa's economic performance: limitations of the current consensus." Journal of Economic Perspectives 13 (3): 89-114. 
Shettima, Kole Ahmed. 1993. "Structural adjustment and the student movement in Nigeria." Review of African Political Economy 56.

Sneyd, Lauren Q, Alexander Legwegoh, and Evan DG Fraser. 2013. "Food riots: Media perspectives on the causes of food protest in Africa." Food security 5 (4): 485-497.

Ward, Michael D, Andreas Beger, Josh Cutler, Matthew Dickenson, Cassy Dorff, and Ben Radford. 2013. "Comparing GDELT and ICEWS event data." Analysis 21 (1): 267-297.

Xie, Hua, Liangzhi You, and Hiroyuki Takeshima. 2017. "Invest in small-scale irrigated agriculture: A national assessment on potential to expand small-scale irrigation in Nigeria." Agricultural Water Management 193: 251-264.

Zantman, Wilfried. 2002. "Constitutional design and regional favoritism." Journal of Public Economic Theory 4 (1): 71-93.

Zhuravskaya, Ekaterina V. 2000. "Incentives to provide local public goods: fiscal federalism, Russian style." Journal of public economics 76 (3): 337-368. 


\section{A Appendix (For Online Publication)}

\section{Contents}

1 Introduction 2

2 Fiscal Redistribution and Protests in Nigeria $\quad 8$

2.1 Intergovernmental Transfers Under Military and Democratic Rule . . . . . 8

2.2 Protests and Government Responses . . . . . . . . . . . . . . . . . . . 12

2.2 .1 Military Rule ... . . . . . . . . . . . . 12

2.2.2 Democratic Period . . . . . . . . . . . . . . 13

3 Conceptual Framework $\quad 14$

4 Description of Data $\quad 17$

4.1 Public Finance . . . . . . . . . . . . . . . . . . . 17

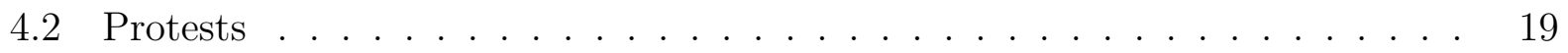

4.3 Political Parties . . . . . . . . . . . . . . . . . . . 21

5 Protests and Fiscal Redistribution $\quad 22$

5.1 Protests and Intergovernmental Transfers . . . . . . . . . . . . . . . . . 22

5.1.1 Mechanisms: The Role of Political Alignment . . . . . . . . . . . . . 23

5.2 OLS Estimates . . . . . . . . . . . . . . . . . 24

5.3 Instrumental Variable Estimates . . . . . . . . . . . . . . 26

5.4 Other Falsification Tests . . . . . . . . . . . . . . . . . . . 31

6 Examining Policing and State Expenditure Outcomes 32

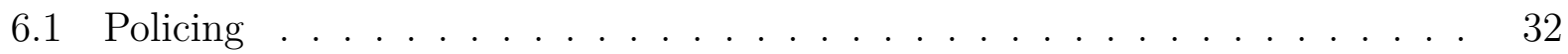

6.2 State Expenditure . . . . . . . . . . . . . . . . . . 34 
A Appendix (For Online Publication) 55

A.1 Data Appendix . . . . . . . . . . . . . . . . . . 60

A.1.1 Data and Variable Descriptions . . . . . . . . . . . . . . 60

A.2 Further Detail on Protests in Nigeria . . . . . . . . . . . . . . . . 64

A.3 Party Politics in Nigeria . . . . . . . . . . . . . . . . . . . . 68

A.4 Robustness . . . . . . . . . . . . . . . . . . . . . . 71

A.5 IV Estimates . . . . . . . . . . . . . . . . . . 73

A.6 Protests and Labor Unions . . . . . . . . . . . . . . . . . . . . . . 78

A.7 Intergovernmental Transfers, Public Service Provision and Tax Morale Outcomes 79

\section{List of Figures}

1 Google trends search interest ranking scores for 'allocation' and 'VAT' terms in Nigeria, 2011-2021 . . . . . . . . . . . . . . . . . . 37

2 Example of archival data (1990) on public finance from the 1997 Annual Abstract of Statistics . . . . . . . . . . . . . . . . . . . . 37

3 Share of intergovernmental transfers (VAT and Allocation) in total revenues in military (1988-1996) and democratic (2000-2016) periods . . . . . . . . 38

4 Share of internally generated revenue (IGR) in total revenues in military (1988-1996) and democratic (2000-2016) periods . . . . . . . . . . 38

$5 \quad$ Mean protest and battles (indicator measure) in military period (1979-1999)

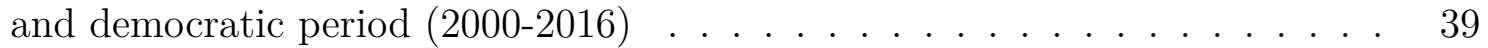

$6 \quad$ Likelihood of governor-president (GP) party alignment in the democratic period 39 
$7 \quad$ Average VAT and Allocation transfers by protest intensity (indicator). Higher variance in VAT transfers than allocation transfers in relatively high vs low protest areas . . . . . . . . . . . . . . . . . 45

A1 Countries with Natural Resource Revenue-Sharing Arrangements. Source:

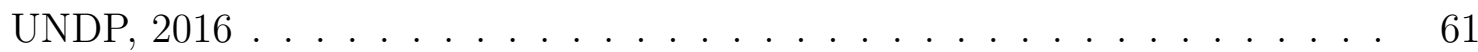

A2 Headlines from the 'decade of protests' . . . . . . . . . . . . . . . . 61

A3 Nigeria with 6 geopolitical (ethnic region proxy) zones colored, LGAs outlined and state names labeled $\ldots \ldots \ldots \ldots$. . . . . . . . . . . . . . 62

A4 Figure showing larger and smaller variance in VAT transfers and Allocation transfers respectively, disbursed in relatively high versus low protest areas, military period $\ldots \ldots \ldots \ldots \ldots \ldots \ldots \ldots$

A5 New York Times article on "Economic Riots" in Nigeria (1989) . . . . . . . 66

A6 News headlines from the 2000s: Workers protest over unpaid salaries in Nigeria 67

A7 Share of state governors from registered political parties, 2000-2016 _ . . . 69

A8 Share of state governors from PDP versus other opposition parties (APC) by

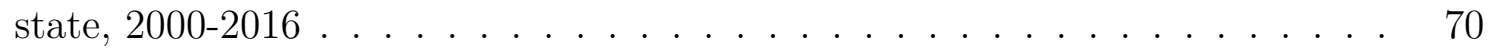

A9 OLS Estimates: Protest, by president-governor alignment, and intergovernmental transfers (VAT, Allocation) in military and democratic periods . . . . 71

A10 Share of households that own a mobile phone, 2008-2015. Source: Demographic and Health Surveys (DHS) _ . . . . . . . . . . . . 77

\section{List of Tables}

1 OLS Estimates: Protest, other events and intergovernmental transfers (VAT, Allocation) and internally generated revenue (IGR), military period . . . . . 40

2 OLS Estimates: Protest, other events and intergovernmental transfers (VAT, Allocation) and internally generated revenue (IGR), democratic period . . . 41 
3 OLS Estimates: Protest, other events and intergovernmental transfers (VAT, Allocation) and internally generated revenue (IGR), democratic period by GP Aligned status . . . . . . . . . . . . . . . . . . . . . . . . . . 42

4 Instrument validity and falsification tests: Links between protest, other events and ethnolinguistic similarity interacted with negative economic shocks instru-

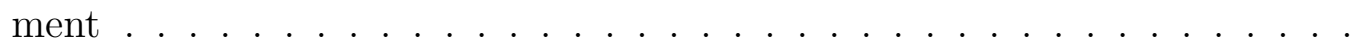

5 IV estimates of the effect of protests on intergovernmental transfers using the ethnolinguistic similarity interacted with negative economic shocks instrument, and comparison OLS estimates, democratic period . . . . . . . . . 44

6 Reduced form estimates for the ethnolinguistic similarity interacted with negative economic shock year instrument and intergovernmental transfers, demo-

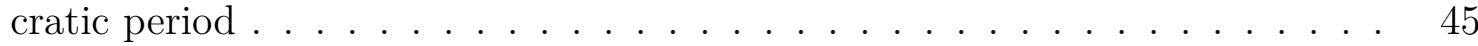

7 OLS Estimates: Protest and policing, share of other major actors in events, democratic period . . . . . . . . . . . . . . . . 46

8 OLS Estimates: Protest and state recurrent and capital expenditures . . . . 47

A1 Google trends top related search query terms to 'allocation' and 'vat' in Nige-

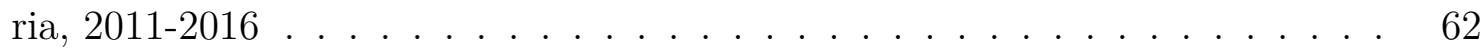

A2 Summary Statistics . . . . . . . . . . . . . . . . 63

A3 Distribution of state governor and president parties, 2000-2016 . . . . . . 69

A4 Balance on geographic and institutional characteristics . . . . . . . . . 72

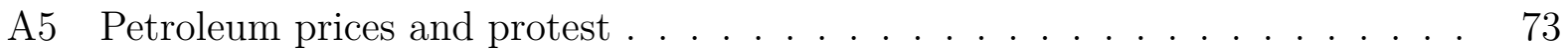

A6 Instrument validity and falsification test: Ethnolinguistic similarity interacted with negative shock year instrument and protest by mobile phone coverage, democratic period . . . . . . . . . . . . . . . . . 74

A7 Falsification test: Ethnolinguistic similarity interacted with negative shock year instrument and battles by mobile phone coverage, democratic period . . 75 
A8 First and second stage for interacted instrument and GP Aligned interaction term, democratic period . . . . . . . . . . . . 76

A9 Protest, battles and share of labor union actors, democratic period . . . . . 78

A10 Summary Statistics of 2018 Tax Morale Respondents . . . . . . . . . . . . 81

A11 Correlations between public service provision and tax morale in 2018 . . . . 82

A12 OLS Estimates: Relationship between historic revenue shares in total state revenues and perceptions of quality of present-day public service provision . 83

A13 OLS Estimates: Relationship between historic revenue shares in total state revenues and and tax morale . . . . . . . . . . . . . 84 


\section{A.1 Data Appendix}

\section{A.1.1 Data and Variable Descriptions}

- Protest data from the military period is from the Global Data on Events, Location and Tone (GDELT) database, which codes contact events from newspapers over the 19791999 military period. The dataset can be found online here: https://www.gdeltproject.org/. It includes a classification for protests/riots, along with other event root codes like "fights" or armed battles and "provide aid", among others. Protest are explicitly coded protest/riot events, while battle events are explicitly coded as previously mentioned. Protest data from the democratic period comes form the Armed Conflict Location and Event Data (ACLED) project, which codes conflict events from newspaper reports starting in 1997 but not before. The latest version of the ACLED 2016 dataset code can be found online here: https://acleddata.com. It includes a classification for Protests and Riots combined in a single category here for comparability with the GDELT data. It also includes a category for "Violence against Civilians" and "Battles". Summary statistics are provided in Table A2.

- Public finance and prison data from the military period with complete data from 1988 to 1996 were digitized from the Nigerian Annual Abstract of Statistics as shown in Figure 2. The data from the democratic period from 2000-2016 were digitized from the Annual Abstract of Statistics and the Nigerian National Bureau of Statistics website here: https://nigerianstat.gov.ng/elibrary. Night Light Density data are from the National Oceanic and Atmospheric Administration (NOAA) database. Summary statistics are provided in Table A2.

- Data on mobile phone ownership comes from the nationally representative Demographic and Health Surveys (DHS) from 4 rounds in 2008, 2010, 2013, 2015, the 
years of available mobile phone ownership data. Data comes from the individual level 'PR' recode DHS dataset which records one record for every household member: https://dhsprogram.com/data/.

- Data on police, military and political party actors participation in protest and battles events comes from the ACLED dataset.

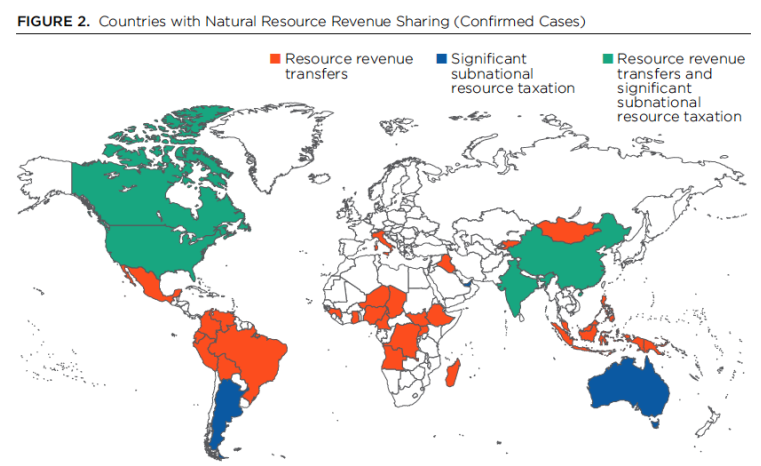

Figure A1: Countries with Natural Resource Revenue-Sharing Arrangements. Source: UNDP, 2016

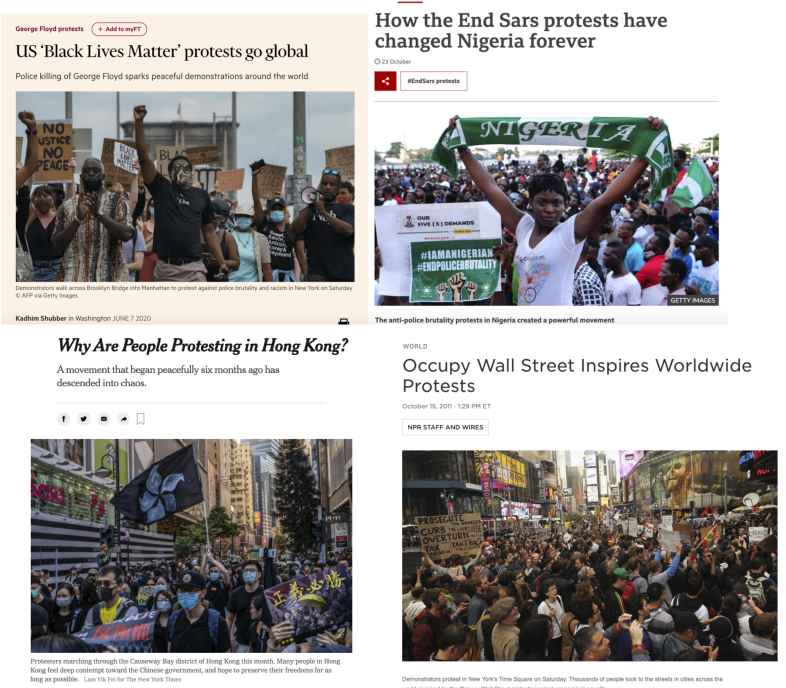

Figure A2: Headlines from the 'decade of protests' 


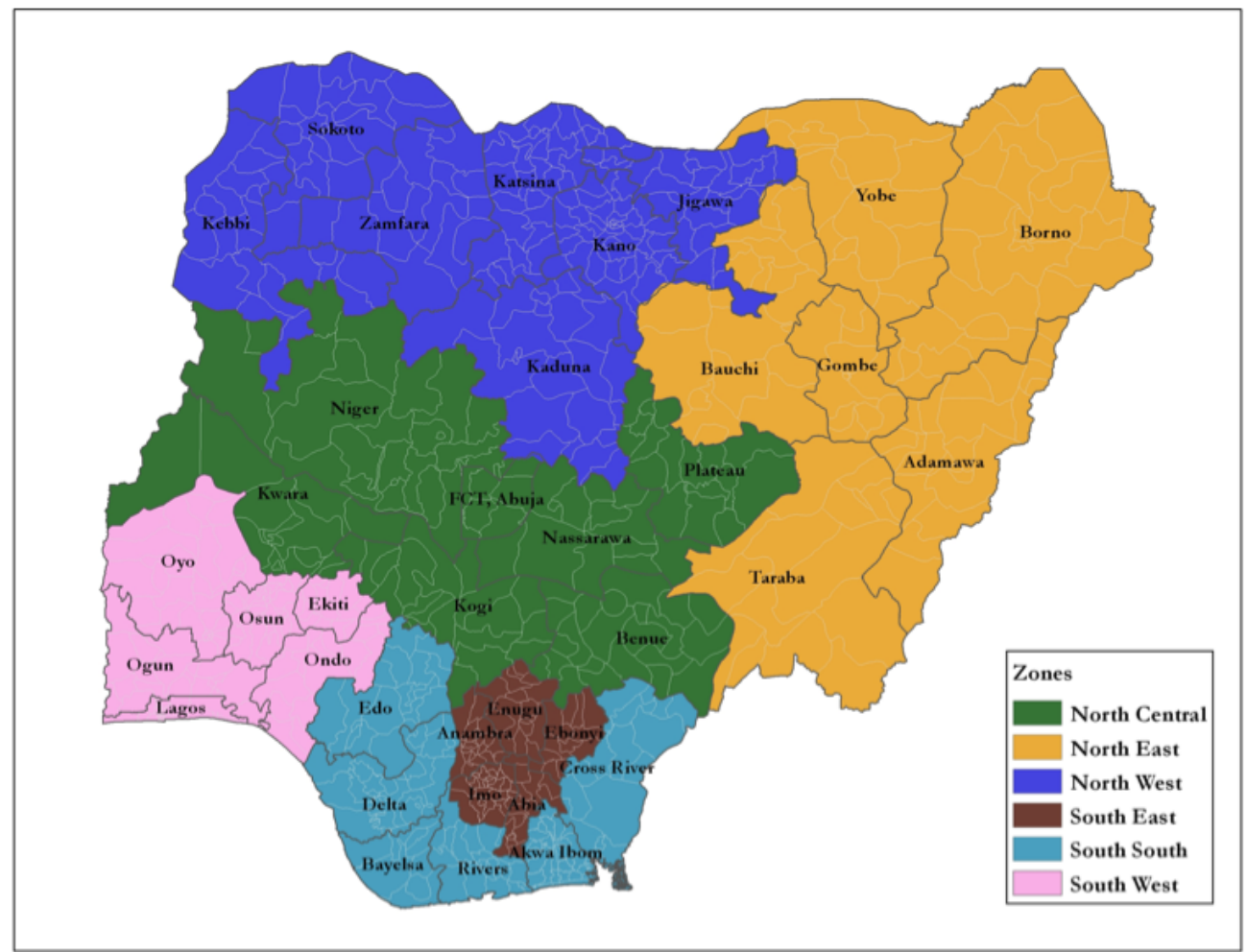

Figure A3: Nigeria with 6 geopolitical (ethnic region proxy) zones colored, LGAs outlined and state names labeled

Table A1: Google trends top related search query terms to 'allocation' and 'vat' in Nigeria, 2011-2016

\section{Allocation}

Top 5 allocation related Google queries, February, 2011 to December, 2021

\begin{tabular}{cc}
\hline Query & Ranking \\
\hline revenue allocation & 100 \\
federal allocation & 78 \\
revenue allocation in nigeria & 51 \\
faac allocation & 42 \\
faac & 36 \\
\hline VAT
\end{tabular}

Top 5 VAT related Google queries, February, 2011 to December, 2021

$\begin{array}{cc}\text { Query } & \text { Ranking } \\ \text { nigeria vat } & 100 \\ \text { vat in nigeria } & 85 \\ \text { what is vat } & 28 \\ \text { vat number } & 18 \\ \text { vat meaning } & 15\end{array}$


Table A2: Summary Statistics

\begin{tabular}{lrrrrr}
\hline \hline Statistic & $\mathrm{N}$ & Mean & St. Dev. & Min & Max \\
& & Public Finance and Protest, Military Period \\
& & & & & \\
& & & & \\
VAT & 130.148 & 10.723 \\
Allocation & 274 & 9.909 & 0.665 & 7.631 & 11.292 \\
IGR & 217 & 8.197 & 1.295 & 2.119 & 12.098 \\
Recurrent Expenditure & 220 & 9.908 & 0.900 & 6.157 & 12.219 \\
Capital Expenditure & 220 & 9.213 & 1.003 & 6.136 & 12.471 \\
VAT Share & 116 & 0.141 & 0.032 & 0.041 & 0.213 \\
Allocation Share & 116 & 0.645 & 0.142 & 0.131 & 0.850 \\
IGR Share & 116 & 0.214 & 0.143 & 0.003 & 0.748 \\
Recurrent Expenditure Share & 220 & 0.647 & 0.171 & 0.128 & 0.959 \\
Capital Expenditure Share & 220 & 0.353 & 0.171 & 0.041 & 0.872 \\
Protest, Continuous & 264 & 0.009 & 0.987 & -0.402 & 5.386 \\
Protest, Indicator & 264 & 0.144 & 0.352 & 0 & 1 \\
Battles, Continuous & 326 & 0.003 & 0.973 & -0.873 & 5.495 \\
Battles, Indicator & 326 & 0.233 & 0.423 & 0 & 1 \\
Ethnolinguistic Similarity x Negative Shock Year & 335 & -0.130 & 0.132 & -0.649 & -0.001 \\
\hline
\end{tabular}

Public Finance and Protest, Democratic Period

VAT

Allocation

$\begin{array}{lllll}612 & 22.488 & 0.535 & 20.998 & 25.053\end{array}$

IGR

Recurrent Expenditure

612

24.098

0.447

22.812

25.078

$\begin{array}{lllll}180 & 22.727 & 1.002 & 20.639 & 26.371\end{array}$

Capital Expenditure

VAT Share

180

24.416

0.597

23.030

26.200

180

23.635

3.679

0.000

26.510

180

0.157

0.027

0.077

0.248

Allocation Share

IGR Share

Recurrent Expenditure Share

180

0.646

0.136

0.118

0.805

180

0.197

0.144

0.023

0.736

Capital Expenditure Share

180

0.558

0.195

0.129

1.000

Governor-President (GP) Aligned

0.442

0.195

0.000

0.871

612

0.690

0.463

$-0.045$

0.918

0

1

Protest, Indicator

0.310

0.463

$-1.031$

4.245

352

0.073

1.035

0

$-0.766$

1

Battles, Continuous
Battles, Indicator

0.258

0.438

0

5.598

$-0.129$

0.142

$-0.707$

1

Ethnolinguistic Similarity x Negative Shock Year 612

Notes: Protest, Continuous is a z-score representing standard deviations from the national mean. Protest, Indicator is an indicator that equals one if the z-score is greater than 0. All public finance values are logs of real values relative to 2010 . IGR is internally generated revenue and VAT are transfers from the Value Added Tax revenue. Revenue shares are divided by total revenue, and expenditure shares are divided by total expenditure. 

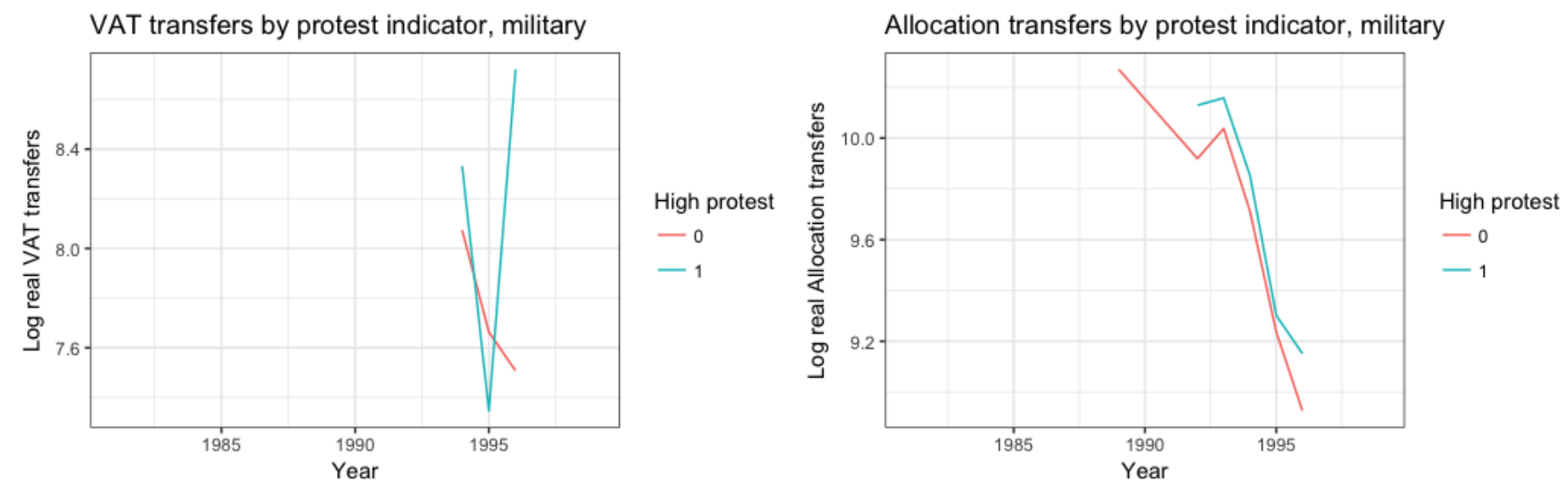

Figure A4: Figure showing larger and smaller variance in VAT transfers and Allocation transfers respectively, disbursed in relatively high versus low protest areas, military period

\section{A.2 Further Detail on Protests in Nigeria}

Another example of protests in Nigeria comes from the anti-oil protests in Nigeria's southern Niger Delta region. The anti-oil protests in the Niger Delta were driven by residents in Nigeria's southern oil producing region, who protested the environmental damage caused by oil production, including uncompensated oil spills and damage to farming and fishery, the primary livelihood of residents in the region from operating companies like Royal Dutch Shell (Frynas, 2001; Osaghae, 1995). The protests were ongoing for many years, with the most famous instance being the anti-Shell protests led by the Movement for the Survival of the Ogoni People (MOSOP) and culminating in the infamous execution of the movement's leader, Ken Saro-Wiwa, by then military head of state Sani Abacha, to much international outcry in 1995 (Frynas, 2001). The protests led to a number of concessions from the federal government, like the creation of an Oil Mineral Producing Areas Development Commission (OMPADEC) that allocated $1.5 \%$ to $3 \%$ of government revenue to these regions. It also led to the introduction of the $13 \%$ derivation to oil producing areas rule in the 1999 constitution. The protests were also followed by repressive tactics from military governments, including killings, arrests and floggings of protesters (Osaghae, 1995). Protests continue in this region 
till the present, with state residents demanding an increase in transfers and ownership rights from the federal government for exploitation of oil resources in their region (Frynas, 2001).

Sixteen states account for all of the high intensity protests in the military period, while 24 states account for $65 \%$ of this sample in the democratic period. $31 \%$ of high intensity protests in the military period were in the Niger Delta region, and $13 \%$ of protest in the SAP protests region in southwestern Nigeria following the historical account in Section $2^{32}$. In the democratic period, 33\% of high intensity protests were in the Niger Delta region, $33 \%$ were in states where the likelihood of the president and state governor being from the same party was relatively low, following accounts of opposition party led protests described in Section 2. Altogether, the Niger Delta and opposition party states account for $66 \%$ of the high intensity protests in the democratic period ${ }^{33}$.

\footnotetext{
${ }^{32}$ The Niger Delta states include Delta, Rivers, Bayelsa, Edo and Ondo.The SAP protests were concentrated in Lagos, Ogun and Osun states.

${ }^{33}$ The Niger Delta states include Delta, Edo, Rivers, Bayelsa, Imo Ondo, Akwa-Ibom and Abia. The opposition party states include Ekiti, Lagos, Osun, Ogun, Oyo, Kware, Kogi and Borno.
} 


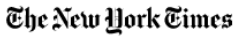

\section{Economic Riots Are Spreading in Nigeria}

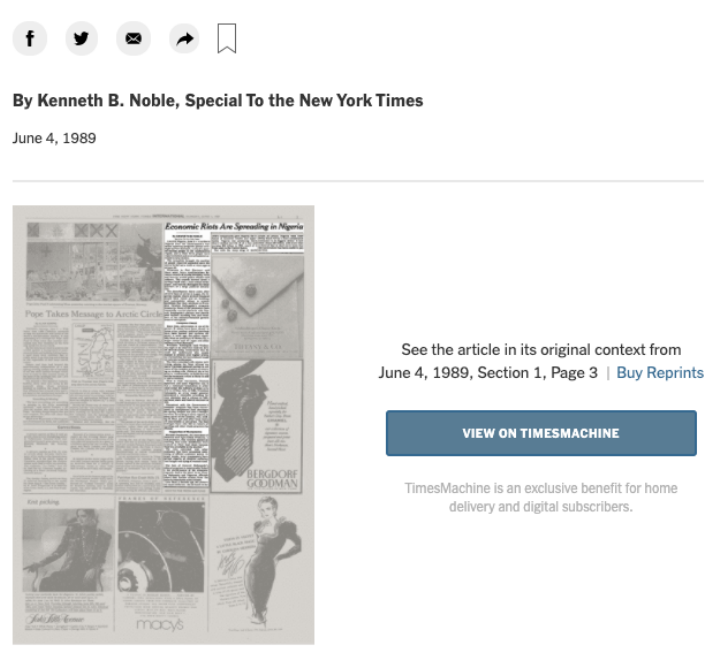

The New York Times Archives

About the Archive

This is a digitized version of an article from The Times's print archive, before the start of online publication in 1996. To preserve these articles as they originally appeared, The Times does not alter, edit or update them.

Occasionally the digitization process introduces transcription errors or other problems; we are continuing to work to improve these archived versions.

A strike in Nigeria over the Government's economic austerity program spread overnight to Port Harcourt, a city of a quartermillion people in the southeastern region, and at least three people

Figure A5: New York Times article on "Economic Riots" in Nigeria (1989) 


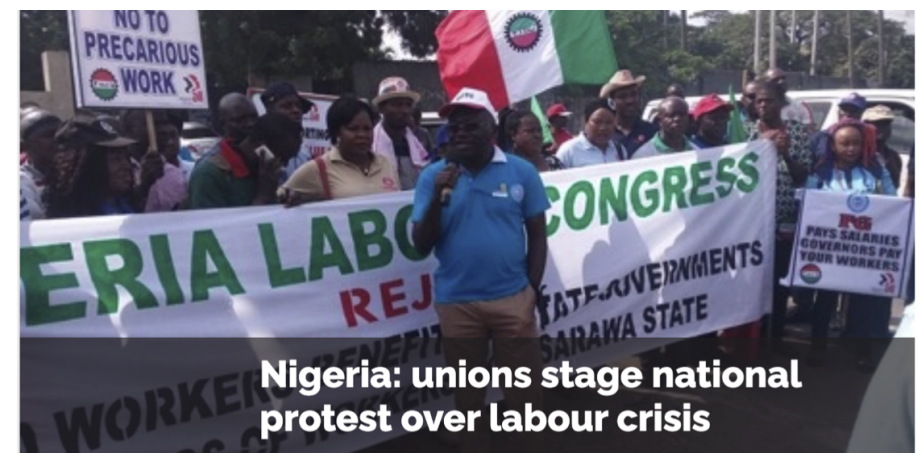

\section{aras}

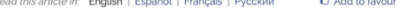

31 August, 2016 On 23 August 2016 . Nigerian unions took part tin a national

Workers protest non-payment of over three years salaries in Cross River

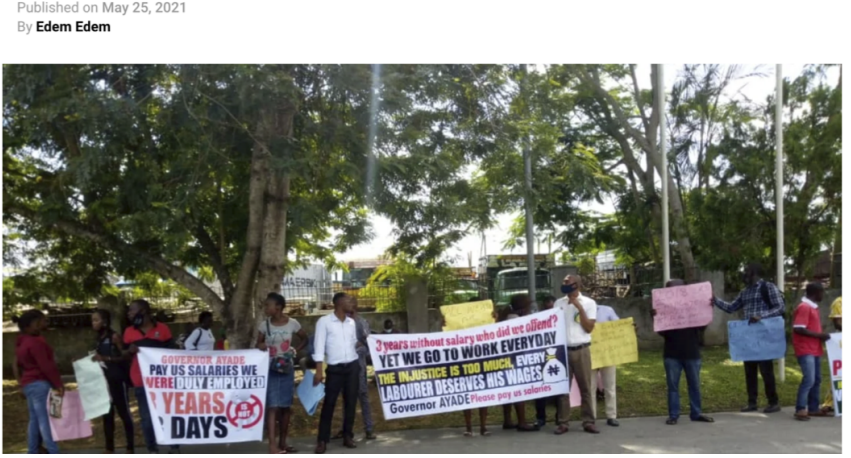

Figure A6: News headlines from the 2000s: Workers protest over unpaid salaries in Nigeria 


\section{A.3 Party Politics in Nigeria}

Though political parties have a long history pre the 1999 democratic elections in Nigeria, only 3 of 9 existing parties (namely Alliance for Democracy (AD), the All People's Party (APP), and the People's Democratic Party (PDP)) were granted registration by the then military president Abdulsalami Abubakar in 1999 upon transition to democracy (Azeez, 2009). The PDP then dominated presidential elections for 15 years with $88 \%$ of presidents elected between 2000 and 2016 coming from PDP. Gubernatorial elections in Nigeria are usually very localized events, with citizens focused on regional issues, often along ethnic lines (Azeez, 2009). Ten parties have elected governors between 2010 and 2016 as shown in Table A3. Most governors over the democratic period have come from the main PDP party, with a drop-off after 2010 following the sudden death of then PDP party president Umaru Yar'Adua in 2010 as shown in Figure A7.

The president's death and the appointment and subsequent election of his vice president, Goodluck Jonathan, the first president from the south-south ethnic region in Nigeria, was heavily contested, with many groups contesting the election of a president from the south-south ethnic region (Owen and Usman, 2015). Jonathan's loss in the 2015 election was reportedly partly as a result of the backlash from his contravening the country's unofficial "power-sharing" rule, an unofficial agreement to alternate power sharing between the north-

ern and southern ethnic regions of the country, by running for re-election (Owen and Usman, 2015). Multiple opposition parties (ACN, ANPP, CPC and APGA) consolidated forces to form the APC party in 2013 ahead of the 2015 elections, and then president Jonathan lost the presidential elections in 2015 becoming the first incumbent to lose re-election in Nigeria's democratic history, and changing the balance of power among parties of elected state governors as well to majority APC as shown in Figure A7 (Owen and Usman, 2015). Figure A8 shows the strong ethnoregional clustering of parties of elected state governors in Nigeria. 
Table A3: Distribution of state governor and president parties, 2000-2016

\begin{tabular}{cc}
\hline \hline State Governor Party & Share of Total \\
\hline PDP & 0.649 \\
APC & 0.118 \\
ANPP & 0.109 \\
AD & 0.036 \\
ACN & 0.029 \\
APGA & 0.021 \\
APP & 0.015 \\
LP & 0.013 \\
PPA & 0.007 \\
CPC & 0.003 \\
\hline \hline President Party & Share of Total \\
\hline PDP & 0.882 \\
APC & 0.118 \\
\hline
\end{tabular}

Share of state governors from each party, 2000-2016

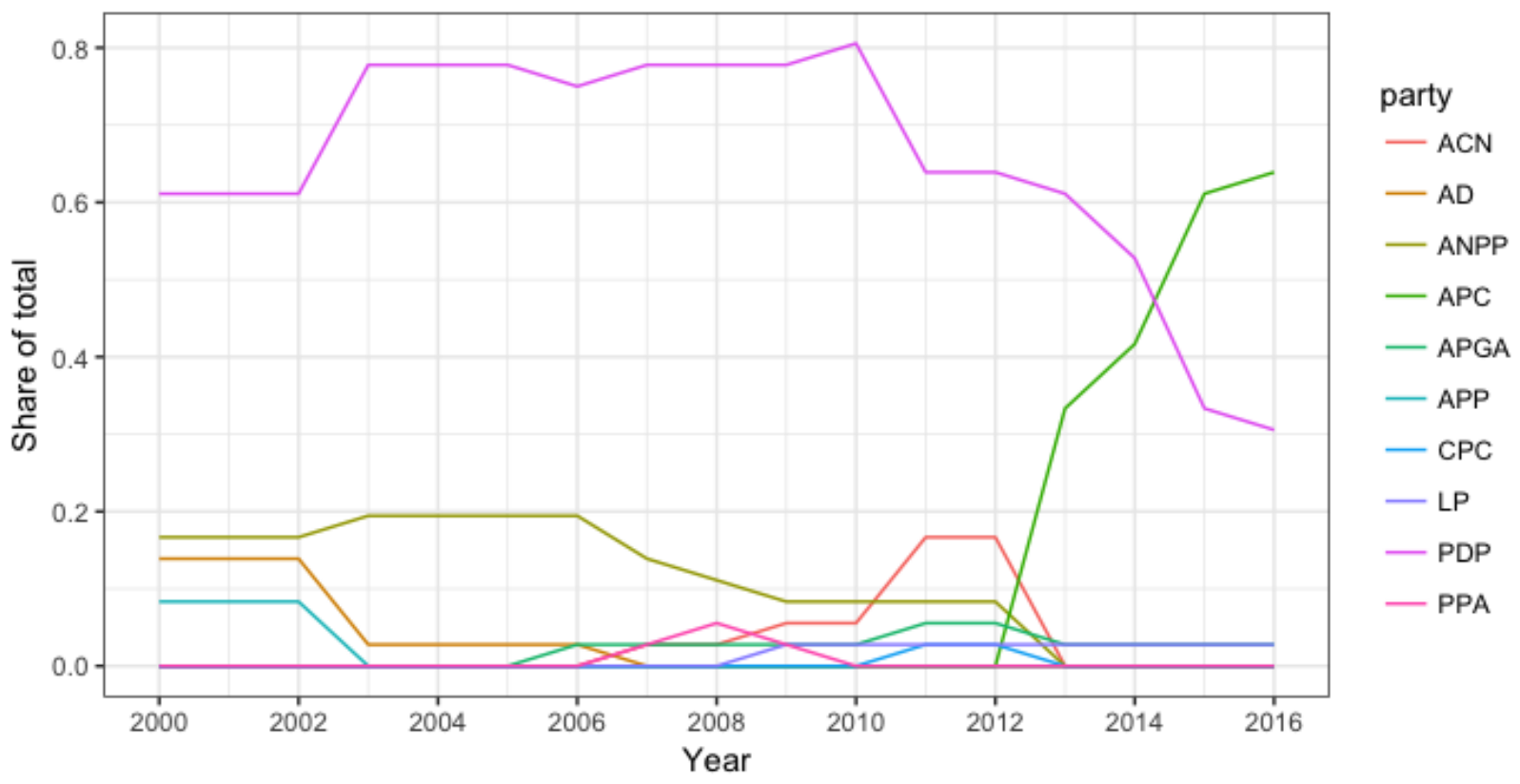

Figure A7: Share of state governors from registered political parties, 2000-2016 

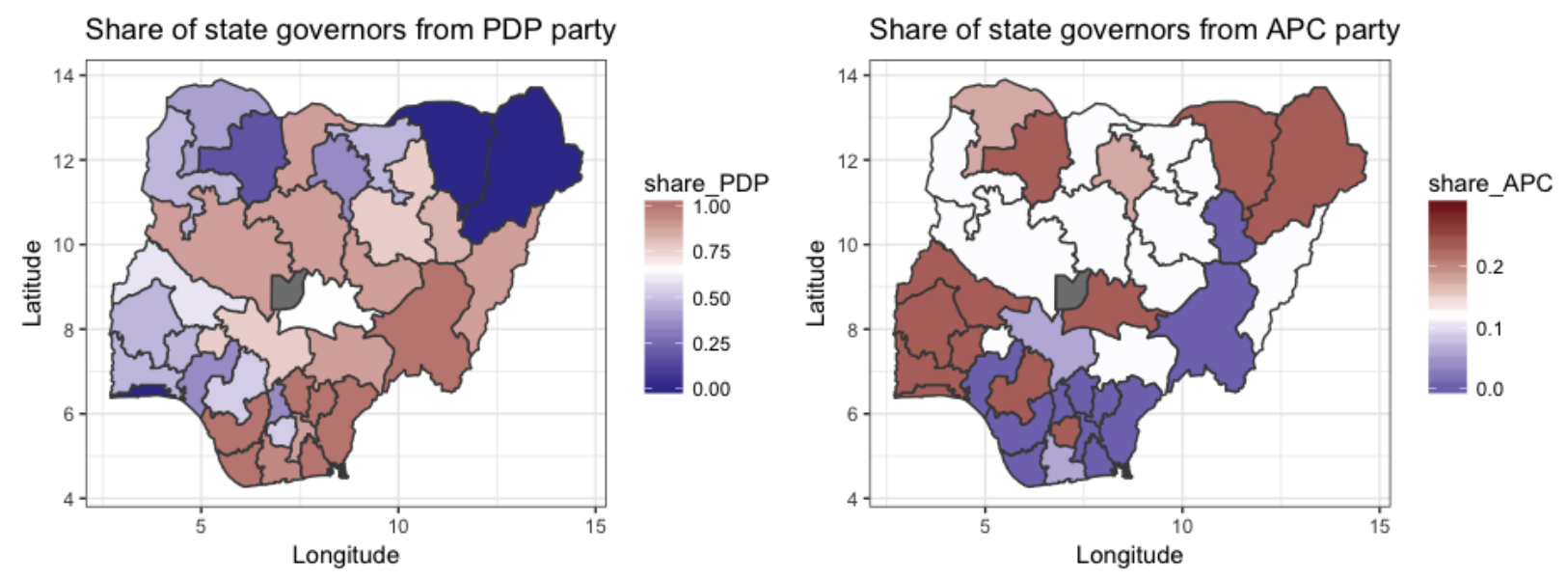

Figure A8: Share of state governors from PDP versus other opposition parties (APC) by state, 2000-2016 


\section{A.4 Robustness}
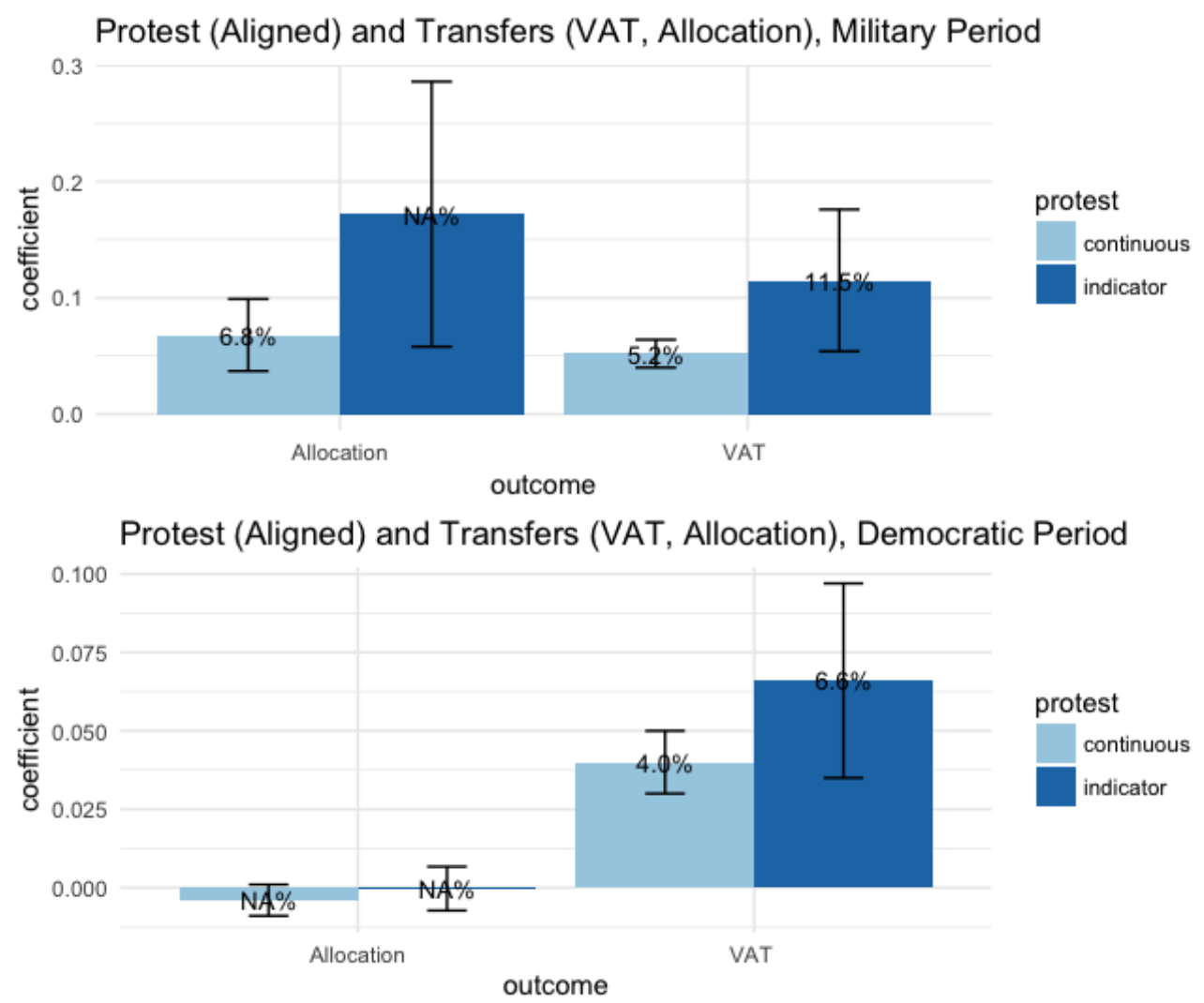

Protest (Non-Aligned) and Transfers (VAT, Allocation), Democratic Period

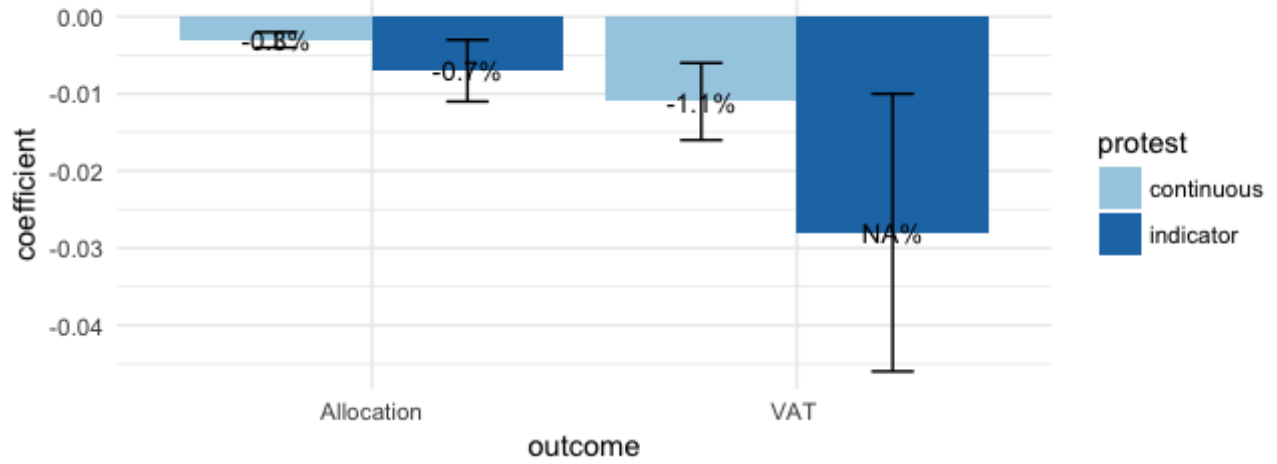

Figure A9: OLS Estimates: Protest, by president-governor alignment, and intergovernmental transfers (VAT, Allocation) in military and democratic periods 
Table A4: Balance on geographic and institutional characteristics

\begin{tabular}{|c|c|c|c|c|c|c|c|c|c|}
\hline & \multicolumn{9}{|c|}{$\begin{array}{l}\text { Panel A: Protest Average and State Characteristics, Military Period } \\
\text { Geographic } \\
\text { Institutional }\end{array}$} \\
\hline & $\begin{array}{l}\text { Petrol } \\
(1)\end{array}$ & $\begin{array}{c}\text { Malaria } \\
(2)\end{array}$ & $\begin{array}{l}\text { Suitability } \\
(3)\end{array}$ & $\begin{array}{l}\text { Elevation } \\
(4)\end{array}$ & $\begin{array}{l}\text { Dist. Coast } \\
(5)\end{array}$ & $\begin{array}{l}\text { Dist. Capital } \\
(6)\end{array}$ & $\begin{array}{c}\text { Slavery } \\
(7)\end{array}$ & $\begin{array}{l}\text { Centralization } \\
(8)\end{array}$ & $\begin{array}{l}\text { Pop. Density } \\
(9)\end{array}$ \\
\hline Protest (Indicator) & $\begin{array}{c}0.187 \\
(0.170)\end{array}$ & $\begin{array}{l}-0.021 \\
(0.016)\end{array}$ & $\begin{array}{r}-0.027 \\
(0.405)\end{array}$ & $\begin{array}{c}58.572 \\
(201.084)\end{array}$ & $\begin{array}{r}-92.216 \\
(70.650)\end{array}$ & $\begin{array}{l}-61.004 \\
(126.718)\end{array}$ & $\begin{array}{c}-212,050.000 \\
(143,023.800)\end{array}$ & $\begin{array}{c}-0.283 \\
(0.442)\end{array}$ & $\begin{array}{c}6,306.232 \\
(3,981.926)\end{array}$ \\
\hline $\begin{array}{l}\text { Observations } \\
\mathrm{R}^{2} \\
\text { District FE }\end{array}$ & $\begin{array}{c}37 \\
0.760 \\
\text { Yes }\end{array}$ & $\begin{array}{c}37 \\
0.214 \\
\text { Yes }\end{array}$ & $\begin{array}{c}37 \\
0.426 \\
\text { Yes }\end{array}$ & $\begin{array}{c}37 \\
0.498 \\
\text { Yes }\end{array}$ & $\begin{array}{c}37 \\
0.912 \\
\text { Yes }\end{array}$ & $\begin{array}{c}37 \\
0.571 \\
\text { Yes }\end{array}$ & $\begin{array}{c}37 \\
0.486 \\
\text { Yes }\end{array}$ & $\begin{array}{c}37 \\
0.494 \\
\text { Yes }\end{array}$ & $\begin{array}{c}37 \\
0.390 \\
\text { Yes }\end{array}$ \\
\hline \multirow{2}{*}{ District FE } & \multicolumn{9}{|c|}{$\begin{array}{l}\text { Panel B: Protest Average and State Characteristics, Democratic Period } \\
\text { Geographic }\end{array}$} \\
\hline & $\begin{array}{l}\text { Petrol } \\
(1)\end{array}$ & $\begin{array}{c}\text { Malaria } \\
(2)\end{array}$ & $\begin{array}{c}\text { Suitability } \\
(3)\end{array}$ & $\begin{array}{c}\text { Elevation } \\
\text { (4) }\end{array}$ & $\begin{array}{c}\text { Dist. Coast } \\
(5)\end{array}$ & $\begin{array}{c}\text { Dist. Capital } \\
(6)\end{array}$ & $\begin{array}{c}\text { Slavery } \\
(7)\end{array}$ & $\begin{array}{c}\text { Centralization } \\
(8)\end{array}$ & $\begin{array}{c}\text { Pop. Density } \\
(9) \\
\end{array}$ \\
\hline Protest (Indicator) & $\begin{array}{c}0.242 \\
(0.191)\end{array}$ & $\begin{array}{c}-0.017 \\
(0.015)\end{array}$ & $\begin{array}{c}0.184 \\
(0.234)\end{array}$ & $\begin{array}{c}178.200 \\
(148.655)\end{array}$ & $\begin{array}{c}11.877 \\
(78.899)\end{array}$ & $\begin{array}{c}-53.644 \\
(86.927)\end{array}$ & $\begin{array}{c}-88,312.000 \\
(54,802.190)\end{array}$ & $\begin{array}{c}0.070 \\
(0.406)\end{array}$ & $\begin{array}{c}2,007.385 \\
(1,473.340)\end{array}$ \\
\hline Observations & 36 & 36 & 36 & 36 & 36 & 36 & 36 & 36 & 36 \\
\hline $\mathrm{R}^{2}$ & 0.771 & 0.246 & 0.438 & 0.530 & 0.911 & 0.529 & 0.462 & 0.490 & 0.220 \\
\hline Zone FE & Yes & Yes & Yes & Yes & Yes & Yes & Yes & Yes & Yes \\
\hline
\end{tabular}

Notes: Regressions estimated by OLS. Robust standard errors in parentheses. Observations at the state level. Zone is geopolitical zone. 'Protest (Indicator)' is the likelihood that a state is a high intensity protest area, taking the long-run average of the Protest indicator over the military and democratic periods of study. Petrol is an indicator that equals 1 if the state has recorded deposits of are distance to sea cost and distance to capital respectively. Distance to capital and seacoast in km. Malaria stability is from the malaria ecology index from Kiszewski et al., (2004). Pop. Density is the average LGA population density in 2006 . Access to River is an indicator for whether or not a state has a river running through it. Slavery is the total exports of slaves from the region during the Atlantic slave trade. Centralization index is the level of precolonial centralization from Murdock ethnicity data (Murdock, 1967) (following Archibong (2019)). *** Significant at the 1 percent level, ** Significant at the 5 percent level, *Significant at the 10 percent level. 
Table A5: Petroleum prices and protest

\begin{tabular}{lcccc}
\hline \hline Sample: & \multicolumn{2}{c}{ Military } & \multicolumn{2}{c}{ Democratic } \\
Outcome: & $(1)$ & $(2)$ & $(3)$ & $(4)$ \\
& Protest (Continuous) & Protest (Indicator) & Protest (Continuous) & Protest (Indicator) \\
& 0.572 & 0.135 & -0.058 & 0.024 \\
Petrol x Petrol Price & $(0.516)$ & $(0.157)$ & $(0.139)$ & $(0.109)$ \\
& {$[0.305]$} & {$[0.476]$} & {$[0.689]$} & $0.839]$ \\
Mean of outcome & 0.009 & 0.144 & -0.018 & 308 \\
Observations & 264 & 264 & 352 & 36 \\
Clusters & 37 & 37 & 36 & Yes \\
\hline District FE & Yes & Yes & Yes & Yes \\
Year FE & Yes & Yes & Yes & 308 \\
\hline \hline
\end{tabular}

Notes: Regressions estimated by OLS. Robust standard errors in parentheses clustered by district. Districts are administrative states in Nigeria. Wild cluster bootstrap (by district) p-values are in brackets. Dependent variables are protest variables. Protest Continuous is the continuous z-score measure of protests and Protest Indicator is measure that equals one if the z-score is greater than 0 as described in text. Petrol is an indicator that equals one if the state is a petroleum producing area. Petrol Price is the log real (US 1984 USD) oil price of petroleum for available data in the military period (1980-1999) and democratic period (2000-2016). *** Significant at the 1 percent level, ** Significant at the 5 percent level, *Significant at the 10 percent level.

\section{A.5 IV Estimates}

Our instrument specification adapts the $E L F_{0.2}$ from Gershman and Rivera (2018). Our results are robust to using $E L F_{0.1}$ and $E L F_{0.3}$ instead to construct the interacted ethnolinguistic similarity instrument. We use available Demographic and Health Surveys (DHS) data on the share of households that own a mobile phone, as shown in Figure A10 to test hypotheses around the predictive power of the interacted instrument by mobile phone coverage in a state. 
Table A6: Instrument validity and falsification test: Ethnolinguistic similarity interacted with negative shock year instrument and protest by mobile phone coverage, democratic period

\begin{tabular}{|c|c|c|c|c|c|c|}
\hline \multirow[t]{2}{*}{ Outcome: } & \multicolumn{6}{|c|}{ Protest (Continuous) } \\
\hline & $(1)$ & $(2)$ & $(3)$ & $(4)$ & $(5)$ & $(6)$ \\
\hline \multicolumn{7}{|l|}{ Ethnolinguistic Similarity } \\
\hline x Negative Shock Year (ESN) & $\begin{array}{c}3.838^{* *} \\
(1.564)\end{array}$ & $\begin{array}{c}0.180 \\
(3.092)\end{array}$ & $\begin{array}{r}-3.534 \\
(5.032)\end{array}$ & $\begin{array}{r}-6.737^{*} \\
(3.569)\end{array}$ & $\begin{array}{r}-8.003^{*} \\
(4.213)\end{array}$ & $\begin{array}{r}-0.988 \\
(3.469)\end{array}$ \\
\hline Phone & & $\begin{array}{l}-1.660 \\
(1.375)\end{array}$ & & & & \\
\hline Phone30 & & & $\begin{array}{c}0.854 \\
(0.691)\end{array}$ & & & \\
\hline Phone40 & & & & $\begin{array}{c}0.098 \\
(0.423)\end{array}$ & & \\
\hline Phone50 & & & & & $\begin{array}{c}0.440 \\
(0.312)\end{array}$ & \\
\hline Phone60 & & & & & & $\begin{array}{c}0.213 \\
(0.279)\end{array}$ \\
\hline ESN x Phone & & $\begin{array}{c}3.413 \\
(2.487)\end{array}$ & & & & \\
\hline ESN x Phone30 & & & $\begin{array}{c}6.683 \\
(4.211)\end{array}$ & & & \\
\hline ESN x Phone40 & & & & $\begin{array}{l}8.673^{* * *} \\
(3.297)\end{array}$ & & \\
\hline ESN x Phone50 & & & & & $\begin{array}{l}9.433^{* * *} \\
(3.582)\end{array}$ & \\
\hline ESN x Phone60 & & & & & & $\begin{array}{c}3.713 \\
(2.783)\end{array}$ \\
\hline Mean of outcome & -0.065 & -0.065 & -0.065 & -0.065 & -0.065 & -0.065 \\
\hline Observations & 105 & 105 & 105 & 105 & 105 & 105 \\
\hline Clusters & 36 & 36 & 36 & 36 & 36 & 36 \\
\hline District FE & Yes & Yes & Yes & Yes & Yes & Yes \\
\hline Year FE & Yes & Yes & Yes & Yes & Yes & Yes \\
\hline
\end{tabular}

Notes: Regressions estimated by OLS. Robust standard errors in parentheses clustered by district. Districts are administrative states in Nigeria. Dependent variable is Protest, described as the continuous z-score measure as described in text. Phone is the average number of individuals that own a mobile phone in the state from 4 rounds of available DHS data in 2008, 2010, 2013 and 2015. PhoneX is an indicator that equals one if $\mathrm{X} \%$ of individuals own a mobile phone, so, for example, Phone20 is an indicator that equals one if $20 \%$ of individuals own a mobile phone. ${ }^{* * *}$ Significant at the 1 percent level, ${ }^{* *}$ Significant at the 5 percent level, ${ }^{*}$ Significant at the 10 percent level. 
Table A7: Falsification test: Ethnolinguistic similarity interacted with negative shock year instrument and battles by mobile phone coverage, democratic period

\begin{tabular}{|c|c|c|c|c|c|c|}
\hline \multirow[t]{2}{*}{ Outcome: } & \multicolumn{6}{|c|}{ Battles (Continuous) } \\
\hline & $(1)$ & $(2)$ & $(3)$ & $(4)$ & $(5)$ & $(6)$ \\
\hline \multicolumn{7}{|l|}{ Ethnolinguistic Similarity } \\
\hline x Negative Shock Year (ESN) & $\begin{array}{c}0.253 \\
(3.018)\end{array}$ & $\begin{array}{c}6.563^{*} \\
(3.496)\end{array}$ & $\begin{array}{c}23.707^{* *} \\
(11.032)\end{array}$ & $\begin{array}{l}18.412^{* *} \\
(8.916)\end{array}$ & $\begin{array}{l}14.867^{*} \\
(7.769)\end{array}$ & $\begin{array}{l}11.047 \\
(7.765)\end{array}$ \\
\hline Phone & & $\begin{array}{c}1.740 \\
(1.373)\end{array}$ & & & & \\
\hline Phone30 & & & $\begin{array}{r}-3.761 \\
(2.812)\end{array}$ & & & \\
\hline Phone40 & & & & $\begin{array}{r}-1.451 \\
(1.452)\end{array}$ & & \\
\hline Phone50 & & & & & $\begin{array}{r}-0.417 \\
(0.815)\end{array}$ & \\
\hline Phone60 & & & & & & $\begin{array}{r}-0.074 \\
(0.580)\end{array}$ \\
\hline ESN x Phone & & $\begin{array}{r}-6.754^{*} \\
(3.661)\end{array}$ & & & & \\
\hline ESN x Phone30 & & & $\begin{array}{r}-22.043^{*} \\
(12.140)\end{array}$ & & & \\
\hline ESN x Phone40 & & & & $\begin{array}{r}-15.501^{*} \\
(8.215)\end{array}$ & & \\
\hline ESN x Phone50 & & & & & $\begin{array}{r}-11.812^{*} \\
(6.682)\end{array}$ & \\
\hline ESN x Phone60 & & & & & & $\begin{array}{r}-7.942 \\
(6.058)\end{array}$ \\
\hline Mean of outcome & -0.027 & -0.027 & -0.027 & -0.027 & -0.027 & -0.027 \\
\hline Observations & 95 & 95 & 95 & 95 & 95 & 95 \\
\hline Clusters & 36 & 36 & 36 & 36 & 36 & 36 \\
\hline District FE & Yes & Yes & Yes & Yes & Yes & Yes \\
\hline Year FE & Yes & Yes & Yes & Yes & Yes & Yes \\
\hline
\end{tabular}

Notes: Regressions estimated by OLS. Robust standard errors in parentheses clustered by district. Districts are administrative states in Nigeria. Dependent variable is Battles, described as the continuous z-score measure as described in text. Phone is the average number of individuals that own a mobile phone in the state from 4 rounds of available DHS data in 2008, 2010, 2013 and 2015. PhoneX is an indicator that equals one if X\% of individuals own a mobile phone, so, for example, Phone20 is an indicator that equals one if $20 \%$ of individuals own a mobile phone. ${ }^{* * *}$ Significant at the 1 percent level, ${ }^{* *}$ Significant at the 5 percent level, ${ }^{*}$ Significant at the 10 percent level. 
Table A8: First and second stage for interacted instrument and GP Aligned interaction term, democratic period

\section{Outcome:}

\section{Panel A: First-Stage Estimates}

Protest (Continuous)

(2)

Ethnolinguistic Similarity

x Negative Shock Year

F-Stat of Excluded Instrument

20.61

$2.963^{* * *}$

(0.653)

$2.963^{* * *}$

$(0.653)$

10.52

20.61

No

No

No

No

GP Aligned Interaction Instrument

Mean of outcome

Observations

$-0.045$

352

Clusters

36
$(0.613)$

(3)

(4)

$2.235^{* * *}$

(0.613)

10.52

No No

No No

Yes Yes

$-0.045 \quad-0.045$

$352 \quad 352$

$36 \quad 36$

\begin{tabular}{lcccc}
\multirow{2}{*}{ Outcome: } & \multicolumn{3}{c}{ Panel B: Second-Stage 2SLS Estimates } \\
& VAT & Allocation & VAT & Allocation \\
& $(1)$ & $(2)$ & $(3)$ & $(4)$ \\
\hline Protest & -0.014 & $-0.021^{* * *}$ & 0.100 & -0.041 \\
& $(0.012)$ & $(0.007)$ & $(0.181)$ & $(0.036)$ \\
Protest x GP Aligned & & & -0.174 & 0.030 \\
& & & $(0.266)$ & $(0.055)$ \\
Mean of outcome & 22.488 & 24.098 & 22.488 & 24.098 \\
Observations & 352 & 352 & 352 & 352 \\
Clusters & 36 & 36 & 36 & 36 \\
\hline \hline District FE & Yes & Yes & Yes & Yes \\
Year FE & Yes & Yes & Yes & Yes \\
\hline \hline
\end{tabular}

Notes: Robust standard errors in parentheses clustered by district. Districts are administrative states in Nigeria. District and year fixed effects are included in all regressions.Dependent variable in Panel A is Protest. Protest is the continuous z-score measure of protests from the ACLED data as described in text. Ethnolinguistic Similarity x Negative Shock Year is the interacted instrument which interacts the degree of ethnolinguistic similarity at the state level with the share of states experiencing negative economic shocks in a year as defined in the text. The GP Aligned Interaction Instrument interacts the previous instrument with the GP Aligned indicator to predict the first stage for the GP Aligned interaction in the regressions in column (3) and column (4). Dependent variables in Panel B and Panel C are intergovernmental transfers: $\log$ real VAT and state allocations at the state level. ***Significant at the 1 percent level, ** Significant at the 5 percent level, *Significant at the 10 percent level. 
Share of individuals that own a mobile phone in Nigeria

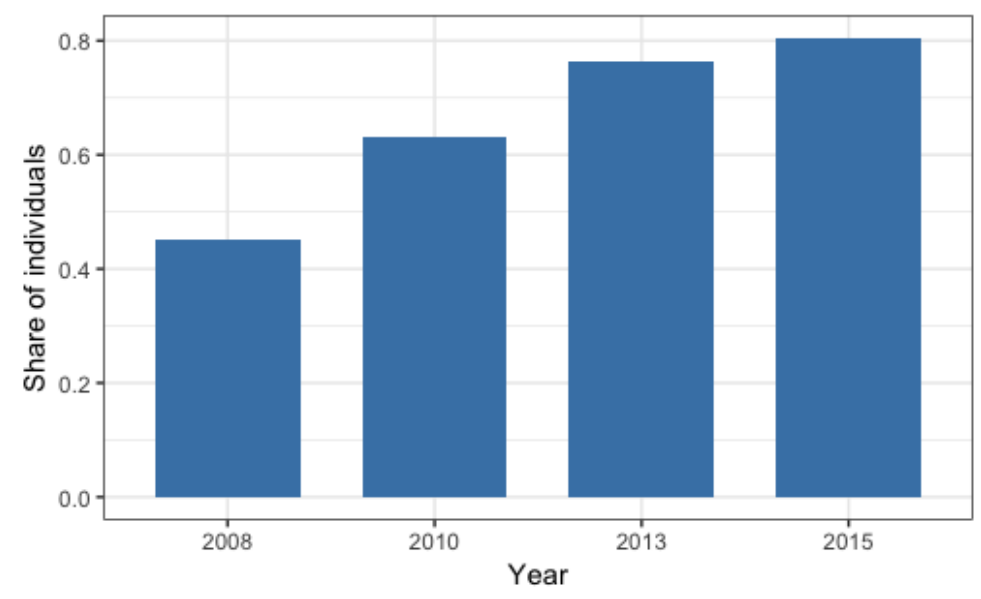

Figure A10: Share of households that own a mobile phone, 2008-2015. Source: Demographic and Health Surveys (DHS) 


\section{A.6 Protests and Labor Unions}

Table A9: Protest, battles and share of labor union actors, democratic period

\begin{tabular}{|c|c|c|c|c|c|c|}
\hline \multirow[t]{2}{*}{ Outcome: } & \multicolumn{6}{|c|}{ Labor Union Share } \\
\hline & $(1)$ & $(2)$ & $(3)$ & $(4)$ & $(5)$ & $(6)$ \\
\hline Protest & $\begin{array}{r}0.008^{*} \\
(0.005)\end{array}$ & $\begin{array}{r}0.009^{*} \\
(0.005)\end{array}$ & $\begin{array}{c}0.004 \\
(0.004)\end{array}$ & & & \\
\hline Governor-President (GP) Aligned & & $\begin{array}{c}0.022 \\
(0.014)\end{array}$ & $\begin{array}{c}0.023 \\
(0.014)\end{array}$ & & $\begin{array}{c}-0.003 \\
(0.022)\end{array}$ & $\begin{array}{c}-0.003 \\
(0.022)\end{array}$ \\
\hline Protest x GP Aligned & & & $\begin{array}{c}0.010 \\
(0.006)\end{array}$ & & & \\
\hline Battles & & & & $\begin{array}{c}0.0002 \\
(0.003)\end{array}$ & $\begin{array}{c}0.0003 \\
(0.003)\end{array}$ & $\begin{array}{r}-0.0003 \\
(0.008)\end{array}$ \\
\hline Battles x GP Aligned & & & & & & $\begin{array}{c}0.001 \\
(0.011)\end{array}$ \\
\hline Mean of outcome & 0.032 & 0.032 & 0.032 & 0.018 & 0.018 & 0.018 \\
\hline Observations & 352 & 352 & 352 & 283 & 283 & 283 \\
\hline Clusters & 36 & 36 & 36 & 36 & 36 & 36 \\
\hline District FE & Yes & Yes & Yes & Yes & Yes & Yes \\
\hline Year FE & Yes & Yes & Yes & Yes & Yes & Yes \\
\hline
\end{tabular}

Notes: Regressions estimated by OLS. Robust standard errors in parentheses clustered by district. Districts are administrative states in Nigeria. Dependent variables are shares of labor union actors in all protest events and in all battles events in each state in (1) to (3) and (4) to (6) respectively over 2000 to 2016 years of available data as described in text. Protest is the continuous z-score measure of protests from the ACLED data as described in text. Battles are defined similarly relative to the $\mathrm{z}$-score. ${ }^{* * *}$ Significant at the 1 percent level, ${ }^{* *}$ Significant at the 5 percent level, ${ }^{*}$ Significant at the 10 percent level. 


\section{A.7 Intergovernmental Transfers, Public Service Provision and Tax Morale Outcomes}

States that receive a larger share of their revenues from these protest-linked transfers may face distorted incentives and reduce public spending on public goods. This may in turn reduce tax morale and compliance in states with higher shares of revenue sourced from transfers following the predictions from the tax literature (Luttmer and Singhal, 2014; Frey and Torgler, 2007; Alm, Jackson, and McKee, 1992; Andreoni, Erard, and Feinstein, 1998).

To test these hypotheses, we use data on public service provision perceptions and tax morale from a new 2018 survey of 16, 228 randomly sampled adult respondents in Nigeria (McCulloch, Moerenhout, and Yang, 2020). Summary statistics are provided in Table A10. We estimate longue-duree regressions linking long-run averages of revenue shares to the public service provision and tax morale outcomes with equations of the following form:

$$
\mathrm{y}_{i s z}=\tau \text { Revenue Share }_{s z}+\mathbf{X}_{i s z}^{\prime} \theta+\mathbf{X}_{s z}^{\prime} \phi+\mu_{z}+\epsilon_{i s z}
$$

where $\mathrm{y}_{i s z}$ is the public service provision perception or tax morale outcome of interest for individual $i$ residing in state $s$ in geopolitical zone $z$. We include vectors of individual level covariates $\mathbf{X}_{i s z}^{\prime}$ and state level controls $\mathbf{X}_{s z}^{\prime}{ }^{34}$. All regressions include zone fixed effects. Standard errors are clustered at the state level and wild cluster bootstrap p-values are included for inference robustness as before. "Revenue Share" is the long-run average ratio of VAT or allocation transfers or IGR in total state revenue in the military, democratic and pooled periods samples. The results are presented in Table A12 and Table A13. Across all periods, there is a significant negative correlation between the long-run average share of VAT transfers in total state revenues and respondent's reported satisfaction with provision

\footnotetext{
${ }^{34}$ Data is described in detail in Appendix A.1.
} 
of electricity and security in their neighborhoods, shown in column (1) of Table A12. The effects are driven by the military period correlations, and respondents from states with a greater long-run share of VAT transfers in total revenues in the military period report lower public service provision across all public service categories- schools, health, water, electricity and security, in column (4) of Table A12. The correlations are robust to the inclusion of a number of population density, individual, geographic and institutional controls.

The tax morale results are reported in Table A13. Respondents from states with higher historic shares of revenues from VAT transfers are less likely to report paying income taxes and express less satisfaction with state and local government spending and less trust in state and local tax officials as shown in column (1) of Table A13. In contrast, respondents from states with higher historic shares of revenues from IGR are more likely to report paying income taxes with no significant association with tax morale in column (3). 
Table A10: Summary Statistics of 2018 Tax Morale Respondents

\begin{tabular}{lrrrrr}
\hline \hline Statistic & $\mathrm{N}$ & Mean & St. Dev. & Min & Max \\
\hline \multicolumn{5}{c}{ Individual Statistics } \\
Age & 16,200 & 32.161 & 10.466 & 18 & 100 \\
Female & 16,228 & 0.500 & 0.500 & 0 & 1 \\
Education & 16,189 & 5.366 & 2.434 & 0 & 11 \\
Urban & 16,228 & 0.700 & 0.458 & 0 & 1 \\
Household Size & 16,228 & 4.519 & 2.771 & 1 & 31 \\
Wealth Index & 15,628 & 2.994 & 1.415 & 1 & 5 \\
\hline
\end{tabular}

Public Service Provision and Tax Attitudes

$\begin{array}{llllll}\text { Schools } & 14,848 & 0.597 & 0.491 & 0 & 1 \\ \text { Health } & 14,444 & 0.550 & 0.498 & 0 & 1 \\ \text { Water } & 11,986 & 0.375 & 0.484 & 0 & 1 \\ \text { Electricity } & 14,231 & 0.371 & 0.483 & 0 & 1 \\ \text { Security } & 13,704 & 0.390 & 0.488 & 0 & 1 \\ \text { Paid Income Tax } & 16,228 & 0.195 & 0.396 & 0 & 1 \\ \text { Tax Authorities Right } & 13,150 & 0.788 & 0.409 & 0 & 1 \\ \text { Satisfied With State Spending } & 13,577 & 0.336 & 0.473 & 0 & 1 \\ \text { Satisfied With LGA Spending } & 13,506 & 0.290 & 0.454 & 0 & 3 \\ \text { Trust State Tax Officials } & 15,506 & 0.855 & 0.862 & 0 & 2 \\ \text { Trust Local Tax Officials } & 15,507 & 0.776 & 0.874 & 0 & 2 \\ \text { Likelihood State Misuse Tax } & 15,582 & 1.141 & 0.755 & 0 & \end{array}$

Notes: Schools, Health, Water, Electricity and Security are indicators that equal one if the respondent states they are "somewhat satisfied" or "very satisfied" with the service in their area and 0 if they state that they are somewhat or very dissatisfied with the service. Respondent tax attitudes as described in the Data Appendix. 
Table A11: Correlations between public service provision and tax morale in 2018

\begin{tabular}{|c|c|c|c|c|c|c|c|c|}
\hline Outcome: & $\begin{array}{c}\text { Satisfied State } \\
\text { (1) }\end{array}$ & $\begin{array}{c}\text { Satisfied Local } \\
(2)\end{array}$ & $\begin{array}{c}\text { Trust State Tax } \\
\text { (3) }\end{array}$ & $\begin{array}{c}\text { Trust Local Tax } \\
\text { (4) }\end{array}$ & $\begin{array}{l}\text { Local Misuse Tax } \\
\text { (5) }\end{array}$ & $\begin{array}{c}\text { State Misuse Tax } \\
\text { (6) } \\
\end{array}$ & $\begin{array}{c}\text { Paid Income Tax } \\
(7) \\
\end{array}$ & $\begin{array}{c}\text { Tax Authorities Right } \\
\text { (8) }\end{array}$ \\
\hline Mean of outcome & $\begin{array}{c}0.271^{* * *} \\
(0.015) \\
{[0.000]} \\
0.336\end{array}$ & $\begin{array}{c}0.260^{* * *} \\
(0.017) \\
{[0.000]} \\
0.290\end{array}$ & $\begin{array}{c}0.178^{* * *} \\
(0.044) \\
{[0.000]} \\
0.855\end{array}$ & $\begin{array}{c}0.254^{* * *} \\
(0.050) \\
{[0.000]} \\
0.776\end{array}$ & $\begin{array}{c}-0.095^{* * *} \\
(0.035) \\
{[0.023]} \\
1.108\end{array}$ & $\begin{array}{c}-0.052^{*} \\
(0.032) \\
{[0.128]} \\
1.141\end{array}$ & $\begin{array}{c}0.006 \\
(0.014) \\
{[0.659]} \\
0.195\end{array}$ & $\begin{array}{c}0.076^{* * *} \\
(0.025) \\
{[0.018]} \\
0.788\end{array}$ \\
\hline Mean of outcome & $\begin{array}{c}0.275^{* * *} \\
(0.016) \\
{[0.000]} \\
0.336 \\
\end{array}$ & $\begin{array}{c}0.273^{* * *} \\
(0.018) \\
{[0.000]} \\
0.290 \\
\end{array}$ & $\begin{array}{c}0.186^{* * *} \\
(0.039) \\
{[0.000]} \\
0.855\end{array}$ & $\begin{array}{c}0.256^{* * *} \\
(0.032) \\
{[0.000]} \\
0.776\end{array}$ & $\begin{array}{c}-0.097^{* * *} \\
(0.036) \\
{[0.025]} \\
1.108\end{array}$ & $\begin{array}{c}-0.047 \\
(0.034) \\
{[0.180]} \\
1.141 \\
\end{array}$ & $\begin{array}{c}0.003 \\
(0.014) \\
{[0.819]} \\
0.195 \\
\end{array}$ & $\begin{array}{c}0.066^{* * *} \\
(0.023) \\
{[0.017]} \\
0.788\end{array}$ \\
\hline Mean of outcome & $\begin{array}{c}0.220^{* * *} \\
(0.024) \\
{[0.000]} \\
0.336\end{array}$ & $\begin{array}{c}0.236^{* * *} \\
(0.019) \\
{[0.000]} \\
0.290\end{array}$ & $\begin{array}{c}0.164^{* * *} \\
(0.043) \\
{[0.001]} \\
0.855\end{array}$ & $\begin{array}{c}0.225^{* * *} \\
(0.040) \\
{[0.000]} \\
0.776\end{array}$ & $\begin{array}{c}-0.050 \\
(0.032) \\
{[0.161]} \\
1.108\end{array}$ & $\begin{array}{c}0.010 \\
(0.040) \\
{[0.834]} \\
1.141 \\
\end{array}$ & $\begin{array}{c}0.007 \\
(0.011) \\
{[0.471]} \\
0.195 \\
\end{array}$ & $\begin{array}{c}0.029 \\
(0.029) \\
{[0.361]} \\
0.788\end{array}$ \\
\hline $\begin{array}{l}\text { Electricity } \\
\text { Mean of outcome }\end{array}$ & $\begin{array}{l}0.227^{* * *} \\
{[0.000]} \\
0.336\end{array}$ & $\begin{array}{c}0.221^{* * *} \\
{[0.000]} \\
0.290 \\
\end{array}$ & $\begin{array}{c}0.091^{* *} \\
{[0.042]} \\
0.855\end{array}$ & $\begin{array}{c}0.126^{* * *} \\
{[0.000]} \\
0.776\end{array}$ & $\begin{array}{c}-0.019 \\
{[0.485]} \\
1.108\end{array}$ & $\begin{array}{c}-0.009 \\
{[0.753]} \\
1.141 \\
\end{array}$ & $\begin{array}{l}0.024^{* * *} \\
{[0.007]} \\
0.195\end{array}$ & $\begin{array}{c}-0.004 \\
{[0.872]} \\
0.788 \\
\end{array}$ \\
\hline Security & $\begin{array}{c}0.280^{* * *} \\
(0.025) \\
{[0.000]} \\
0.336\end{array}$ & $\begin{array}{c}0.288^{* * *} \\
(0.023) \\
{[0.000]} \\
0.290\end{array}$ & $\begin{array}{c}0.221^{* * *} \\
(0.055) \\
{[0.000]} \\
0.855\end{array}$ & $\begin{array}{c}0.250^{* * *} \\
(0.036) \\
{[0.000]} \\
0.776\end{array}$ & $\begin{array}{c}-0.067^{*} \\
(0.037) \\
{[0.085]} \\
1.108\end{array}$ & $\begin{array}{c}-0.035 \\
(0.049) \\
{[0.526]} \\
1.141\end{array}$ & $\begin{array}{c}0.031^{* *} \\
(0.014) \\
{[0.029]} \\
0.195\end{array}$ & $\begin{array}{c}0.065^{* * *} \\
(0.022) \\
{[0.010]} \\
0.788\end{array}$ \\
\hline $\begin{array}{l}\text { Population Density } \\
\text { Individual Controls } \\
\text { Geographic Controls } \\
\text { Disease Controls } \\
\text { Precolonial and Colonial Controls } \\
\text { Zone FE }\end{array}$ & $\begin{array}{l}\text { Yes } \\
\text { Yes } \\
\text { Yes } \\
\text { Yes } \\
\text { Yes } \\
\text { Yes }\end{array}$ & $\begin{array}{l}\text { Yes } \\
\text { Yes } \\
\text { Yes } \\
\text { Yes } \\
\text { Yes } \\
\text { Yes }\end{array}$ & $\begin{array}{l}\text { Yes } \\
\text { Yes } \\
\text { Yes } \\
\text { Yes } \\
\text { Yes } \\
\text { Yes }\end{array}$ & $\begin{array}{l}\text { Yes } \\
\text { Yes } \\
\text { Yes } \\
\text { Yes } \\
\text { Yes } \\
\text { Yes }\end{array}$ & $\begin{array}{l}\text { Yes } \\
\text { Yes } \\
\text { Yes } \\
\text { Yes } \\
\text { Yes } \\
\text { Yes }\end{array}$ & $\begin{array}{l}\text { Yes } \\
\text { Yes } \\
\text { Yes } \\
\text { Yes } \\
\text { Yes } \\
\text { Yes }\end{array}$ & $\begin{array}{l}\text { Yes } \\
\text { Yes } \\
\text { Yes } \\
\text { Yes } \\
\text { Yes } \\
\text { Yes }\end{array}$ & $\begin{array}{l}\text { Yes } \\
\text { Yes } \\
\text { Yes } \\
\text { Yes } \\
\text { Yes } \\
\text { Yes }\end{array}$ \\
\hline
\end{tabular}

Notes: Regressions estimated by OLS. Robust standard errors in parentheses clustered by state. Wild cluster bootstrap (by state) p-values are in brackets. Dependent variables are reported tax compliance and tax morale outcomes from 2018 area population density in 2006. Individual controls include age, age squared, whether the respondent lives in an urban area, household size, wealth index, educational attainment and gender. Geographic cont rols at the state level include log per capita GDP in 2010, ruggedness, mean elevation, land suitability for agriculture, distance to capital, indicators for petroleum and seacoast. Disease controls at the sub-district level include malaria suitability and tse tse fly suitability in alternate specifications with results unchanged. Precolonial and colonial controls at the ethnicity-level include the level of precolonial centralization and log total exports of slaves from the region during the Atlantic slave trade. ${ }^{* * *}$ Significant at the 1 percent level, ${ }^{* *}$ Significant at the 5 percent level, ${ }^{*}$ Significant at the 10 percent level. 
Table A12: OLS Estimates: Relationship between historic revenue shares in total state revenues and perceptions of quality of present-day public service provision

\begin{tabular}{|c|c|c|c|c|c|c|c|c|c|}
\hline $\begin{array}{l}\text { Sample Within: } \\
\text { Covariate: }\end{array}$ & $\begin{array}{c}\text { VAT Share } \\
(1)\end{array}$ & $\begin{array}{c}\text { All } \\
\text { Allocation Share } \\
(2) \\
\end{array}$ & $\begin{array}{c}\text { IGR Share } \\
(3)\end{array}$ & $\begin{array}{c}\text { VAT Share } \\
(4)\end{array}$ & $\begin{array}{c}\text { Military } \\
\text { Allocation Share } \\
(5) \\
\end{array}$ & $\begin{array}{c}\text { IGR Share } \\
(6) \\
\end{array}$ & $\begin{array}{c}\text { VAT Share } \\
(7)\end{array}$ & $\begin{array}{c}\text { Democratic } \\
\text { Allocation Share } \\
(8) \\
\end{array}$ & $\begin{array}{c}\text { IGR Share } \\
(9)\end{array}$ \\
\hline Mean of outcome & $\begin{array}{c}-4.789 \\
(4.188) \\
{[0.442]} \\
0.557 \\
\end{array}$ & $\begin{array}{c}-0.093 \\
(0.695) \\
{[0.926]} \\
0.557\end{array}$ & $\begin{array}{c}0.171 \\
(0.667) \\
{[0.908]} \\
0.557 \\
\end{array}$ & $\begin{array}{c}-3.671^{* * *} \\
(1.097) \\
{[0.048]} \\
0.559\end{array}$ & $\begin{array}{c}-0.042 \\
(0.630) \\
{[0.967]} \\
0.559\end{array}$ & $\begin{array}{c}0.383 \\
(0.607) \\
{[0.725]} \\
0.559 \\
\end{array}$ & $\begin{array}{c}2.701 \\
(2.422) \\
{[0.429]} \\
0.595 \\
\end{array}$ & $\begin{array}{c}0.207 \\
(0.413) \\
{[0.737]} \\
0.595 \\
\end{array}$ & $\begin{array}{c}-0.209 \\
(0.361) \\
{[0.717]} \\
0.595 \\
\end{array}$ \\
\hline Mean of outcome & $\begin{array}{c}-4.532 \\
(4.467) \\
{[0.525]} \\
0.508\end{array}$ & $\begin{array}{c}-0.077 \\
(0.746) \\
{[0.954]} \\
0.508\end{array}$ & $\begin{array}{c}0.151 \\
(0.720) \\
{[0.927]} \\
0.508\end{array}$ & $\begin{array}{c}-3.299^{* * *} \\
(1.153) \\
{[0.072]} \\
0.510\end{array}$ & $\begin{array}{c}-0.232 \\
(0.647) \\
{[0.813]} \\
0.510\end{array}$ & $\begin{array}{c}0.517 \\
(0.627) \\
{[0.664]} \\
0.510\end{array}$ & $\begin{array}{c}3.040 \\
(2.520) \\
{[0.412]} \\
0.548\end{array}$ & $\begin{array}{c}0.214 \\
(0.454) \\
{[0.763]} \\
0.548\end{array}$ & $\begin{array}{c}-0.220 \\
(0.395) \\
{[0.706]} \\
0.548\end{array}$ \\
\hline Mean of outcome & $\begin{array}{c}-3.760 \\
(4.188) \\
{[0.559]} \\
0.343\end{array}$ & $\begin{array}{c}-0.086 \\
(0.531) \\
{[0.911]} \\
0.343\end{array}$ & $\begin{array}{c}0.141 \\
(0.524) \\
{[0.869]} \\
0.343\end{array}$ & $\begin{array}{c}-3.006^{* * *} \\
(1.041) \\
{[0.096]} \\
0.347\end{array}$ & $\begin{array}{c}0.129 \\
(0.481) \\
{[0.884]} \\
0.347\end{array}$ & $\begin{array}{c}0.157 \\
(0.481) \\
{[0.861]} \\
0.347\end{array}$ & $\begin{array}{c}1.589 \\
(1.782) \\
{[0.519]} \\
0.371\end{array}$ & $\begin{array}{c}0.111 \\
(0.316) \\
{[0.798]} \\
0.371\end{array}$ & $\begin{array}{c}-0.115 \\
(0.275) \\
{[0.783]} \\
0.371\end{array}$ \\
\hline Mean of outcome & $\begin{array}{c}-8.004^{* * *} \\
(1.799) \\
{[0.006]} \\
0.341\end{array}$ & $\begin{array}{c}-0.027 \\
(0.327) \\
{[0.967]} \\
0.341\end{array}$ & $\begin{array}{c}-0.169 \\
(0.306) \\
{[0.754]} \\
0.341 \\
\end{array}$ & $\begin{array}{c}-2.746^{* * *} \\
(0.697) \\
{[0.013]} \\
0.342\end{array}$ & $\begin{array}{c}-0.066 \\
(0.304) \\
{[0.882]} \\
0.342 \\
\end{array}$ & $\begin{array}{c}0.313 \\
(0.287) \\
{[0.505]} \\
0.342 \\
\end{array}$ & $\begin{array}{c}-0.100 \\
(1.380) \\
{[0.972]} \\
0.370 \\
\end{array}$ & $\begin{array}{c}0.094 \\
(0.207) \\
{[0.747]} \\
0.370 \\
\end{array}$ & $\begin{array}{c}-0.072 \\
(0.181) \\
{[0.782]} \\
0.370\end{array}$ \\
\hline Security & $\begin{array}{c}-4.108^{* *} \\
(1.776) \\
{[0.122]}\end{array}$ & $\begin{array}{r}-0.035 \\
(0.262) \\
{[0.933]}\end{array}$ & $\begin{array}{c}0.105 \\
(0.260) \\
{[0.819]}\end{array}$ & $\begin{array}{c}-2.483^{* * *} \\
(0.654) \\
{[0.015]}\end{array}$ & $\begin{array}{r}-0.115 \\
(0.291) \\
{[0.807]}\end{array}$ & $\begin{array}{c}0.128 \\
(0.282) \\
{[0.786]}\end{array}$ & $\begin{array}{c}2.501^{* *} \\
(1.113) \\
{[0.121]}\end{array}$ & $\begin{array}{c}0.197 \\
(0.194) \\
{[0.488]}\end{array}$ & $\begin{array}{r}-0.197 \\
(0.169) \\
{[0.429]}\end{array}$ \\
\hline Mean of outcome & 0.349 & 0.349 & 0.349 & 0.351 & 0.351 & 0.351 & 0.388 & 0.388 & 0.388 \\
\hline Population Density & Yes & Yes & Yes & Yes & Yes & Yes & Yes & Yes & Yes \\
\hline Individual Controls & Yes & Yes & Yes & Yes & Yes & Yes & Yes & Yes & Yes \\
\hline Geographic Controls & Yes & Yes & Yes & Yes & Yes & Yes & Yes & Yes & Yes \\
\hline Disease Controls & Yes & Yes & Yes & Yes & Yes & Yes & Yes & Yes & Yes \\
\hline Precolonial and Colonial Controls & Yes & Yes & Yes & Yes & Yes & Yes & Yes & Yes & Yes \\
\hline Zone FE & Yes & Yes & Yes & Yes & Yes & Yes & Yes & Yes & Yes \\
\hline
\end{tabular}

Notes: Regressions estimated by OLS. Robust standard errors in parentheses clustered by state. Wild cluster bootstrap (by state) p-values are in brackets. Dependent variables are reported satisfaction with public service provision (schools, health clinic, water supply, electricity supply, security) in the respondent's neighborhood for combined military and democratic sample from columns (1) to (3), military period only from columns (4) to (6) and democratic period only from columns (7) to (9). Covariates are long-run average shares of real VAT and state allocations, and real internally generated revenue (GR) in total revenue at the state level as described in text. All regressions use fixed effects at the geopolitical zone level in Nigeria and controls for sub-district or local government area population density in 2006. Individual controls include age, age squared, whether the respondent lives in an urban area,
household size, wealth index, educational attainment and gender. Geographic controls at the state level include log per capita GDP in 2010, ruggedness, mean elevation, land suitability for agriculture, distance to capital, indicars for petroleum and seacoast. Disease controls at the sub-district level include malaria suitability and tse tse fly suitability in alternate specifications with results unchanged. Precolonial and colonial controls at the ethnicity-level include the level of precolonial centralization and log total exports of slaves from the region during the Atlantic slave trade ${ }^{* * *}$ Significant at the 1 percent level, ** Significant at the 5 percent level, *Significant at the 10 percent level. 
Table A13: OLS Estimates: Relationship between historic revenue shares in total state revenues and and tax morale

\begin{tabular}{|c|c|c|c|c|c|c|c|c|c|}
\hline $\begin{array}{l}\text { Sample Within: } \\
\text { Covariate: }\end{array}$ & $\begin{array}{c}\text { VAT Share } \\
(1)\end{array}$ & $\begin{array}{c}\text { All } \\
\text { Allocation Share } \\
(2) \\
\end{array}$ & $\begin{array}{c}\text { IGR Share } \\
(3)\end{array}$ & $\begin{array}{c}\text { VAT Share } \\
(4)\end{array}$ & $\begin{array}{c}\text { Military } \\
\text { Allocation Share } \\
(5)\end{array}$ & $\begin{array}{c}\text { IGR Share } \\
(6)\end{array}$ & $\begin{array}{c}\text { VAT Share } \\
(7)\end{array}$ & $\begin{array}{c}\text { Democratic } \\
\text { Allocation Share } \\
(8)\end{array}$ & $\begin{array}{c}\text { IGR Share } \\
(9)\end{array}$ \\
\hline Mean of outcome & $\begin{array}{c}-3.680^{* * *} \\
(1.104) \\
{[0.027]} \\
0.164\end{array}$ & $\begin{array}{c}-0.192^{*} \\
(0.110) \\
{[0.217]} \\
0.164\end{array}$ & $\begin{array}{c}0.239^{* *} \\
(0.106) \\
{[0.089]} \\
0.164\end{array}$ & $\begin{array}{c}-1.163^{* *} \\
(0.455) \\
{[0.106]} \\
0.167\end{array}$ & $\begin{array}{c}-0.015 \\
(0.117) \\
{[0.942]} \\
0.167\end{array}$ & $\begin{array}{c}0.124 \\
(0.105) \\
{[0.334]} \\
0.167\end{array}$ & $\begin{array}{c}-1.598^{* *} \\
(0.659) \\
{[0.119]} \\
0.193\end{array}$ & $\begin{array}{c}-0.234^{* *} \\
(0.103) \\
{[0.107]} \\
0.193\end{array}$ & $\begin{array}{c}0.210^{* *} \\
(0.091) \\
{[0.095]} \\
0.193\end{array}$ \\
\hline Satisfied With State Spending & $\begin{array}{c}-7.551^{* *} \\
(3.377) \\
{[0.144]} \\
0.298\end{array}$ & $\begin{array}{c}-0.308 \\
(0.508) \\
{[0.717]} \\
0.298\end{array}$ & $\begin{array}{c}0.412 \\
(0.504) \\
{[0.673]} \\
0.298\end{array}$ & $\begin{array}{c}-3.235^{* * *} \\
(1.143) \\
{[0.082]} \\
0.300\end{array}$ & $\begin{array}{c}-0.215 \\
(0.509) \\
{[0.769]} \\
0.300\end{array}$ & $\begin{array}{c}0.504 \\
(0.470) \\
{[0.532]} \\
0.300\end{array}$ & $\begin{array}{c}2.957 \\
(1.965) \\
{[0.311]} \\
0.335\end{array}$ & $\begin{array}{c}0.180 \\
(0.304) \\
{[0.644]} \\
0.335\end{array}$ & $\begin{array}{c}-0.192 \\
(0.268) \\
{[0.619]} \\
0.335\end{array}$ \\
\hline Mean of outcome & $\begin{array}{c}-7.478^{* *} \\
(3.349) \\
{[0.149]} \\
0.249 \\
\end{array}$ & $\begin{array}{c}-0.311 \\
(0.497) \\
{[0.722]} \\
0.249 \\
\end{array}$ & $\begin{array}{c}0.414 \\
(0.494) \\
{[0.644]} \\
0.249 \\
\end{array}$ & $\begin{array}{c}-3.605^{* * *} \\
(1.040) \\
{[0.031]} \\
0.251 \\
\end{array}$ & $\begin{array}{c}-0.117 \\
(0.506) \\
{[0.892]} \\
0.251 \\
\end{array}$ & $\begin{array}{c}0.450 \\
(0.461) \\
{[0.564]} \\
0.251 \\
\end{array}$ & $\begin{array}{c}2.842 \\
(1.916) \\
{[0.292]} \\
0.288 \\
\end{array}$ & $\begin{array}{c}0.170 \\
(0.297) \\
{[0.681]} \\
0.288 \\
\end{array}$ & $\begin{array}{c}-0.183 \\
(0.263) \\
{[0.619]} \\
0.288 \\
\end{array}$ \\
\hline Trust State Tax Officials & $\begin{array}{c}-8.828^{* * *} \\
(3.179) \\
{[0.130]} \\
0.809\end{array}$ & $\begin{array}{c}0.037 \\
(0.549) \\
{[0.962]} \\
0.809\end{array}$ & $\begin{array}{c}0.127 \\
(0.522) \\
{[0.837]} \\
0.809\end{array}$ & $\begin{array}{c}-3.323^{* * *} \\
(1.214) \\
{[0.012]} \\
0.811\end{array}$ & $\begin{array}{c}-0.379 \\
(0.343) \\
{[0.409]} \\
0.811\end{array}$ & $\begin{array}{c}0.665^{*} \\
(0.382) \\
{[0.201]} \\
0.811\end{array}$ & $\begin{array}{c}2.128 \\
(2.052) \\
{[0.436]} \\
0.853\end{array}$ & $\begin{array}{c}0.278 \\
(0.320) \\
{[0.525]} \\
0.853\end{array}$ & $\begin{array}{c}0.254 \\
(0.283) \\
{[0.523]} \\
0.853\end{array}$ \\
\hline Trust Local Tax Officials & $\begin{array}{c}-12.582^{* * *} \\
(3.180) \\
{[0.032]}\end{array}$ & $\begin{array}{c}-0.071 \\
(0.683) \\
{[0.944]}\end{array}$ & $\begin{array}{l}0.291 \\
(0.630) \\
{[0.756]}\end{array}$ & $\begin{array}{c}-4.713^{* * *} \\
(1.235) \\
{[0.009]}\end{array}$ & $\begin{array}{c}-0.402 \\
(0.427) \\
{[0.478]}\end{array}$ & $\begin{array}{c}0.819^{*} \\
(0.431) \\
{[0.210]}\end{array}$ & $\begin{array}{c}1.381 \\
(2.578) \\
{[0.715]}\end{array}$ & $\begin{array}{c}0.239 \\
(0.435) \\
{[0.688]}\end{array}$ & $\begin{array}{c}-0.210 \\
(0.382) \\
{[0.714]}\end{array}$ \\
\hline Mean of outcome & 0.720 & 0.720 & 0.720 & 0.723 & 0.723 & 0.723 & 0.773 & 0.773 & 0.773 \\
\hline Population Density & Yes & Yes & Yes & Yes & Yes & Yes & Yes & Yes & Yes \\
\hline Individual Controls & Yes & Yes & Yes & Yes & Yes & Yes & Yes & Yes & Yes \\
\hline Geographic Controls & Yes & Yes & Yes & Yes & Yes & Yes & Yes & Yes & Yes \\
\hline Disease Controls & Yes & Yes & Yes & Yes & Yes & Yes & Yes & Yes & Yes \\
\hline Precolonial and Colonial Controls & Yes & Yes & Yes & Yes & Yes & Yes & Yes & Yes & Yes \\
\hline Zone FE & Yes & Yes & Yes & Yes & Yes & Yes & Yes & Yes & Yes \\
\hline
\end{tabular}

Notes: Regressions estimated by OLS. Robust standard errors in parentheses clustered by state. Wild cluster bootstrap (by state) p-values are in brackets. Dependent variables are respondent's report of whether they paid income tax in the last year (Paid Income Tax), "satisfaction with the way state admin has spent tax money" (Satisfied With State Spending), "satisfaction with the way LGA has spent money collected form levies " (Satisfied With LGA Spending), "trust in state tax officials to collect tax revenue fairly" (Trust State Tax Officials), "trust in local government tax officials to collect revenue fairly" (Trust Local Tax Officials) from 2018 survey data for combined military and democratic sample from columns (1) to (3), military period only from columns (4) to (6) and democratic period only from columns ( 7 ) to (9). Covariates are long-run average shares of log real VAT and state allocations, and $\log$ real internally generated revenue (IGR) in total revenue at the state level as described in text. All regressions use fixed effects at the geopolitical zone level in Nigeria and controls for sub-district or local government area include log per capita GDP in 2010, ruggedness, mean elevation, land suitability for agriculture, distance to capital, indicators for petroleum and seacoast. Disease controls at the sub-district level include malaria suitability and tse tse fly suitability in alternate specifications with results unchanged. Precolonial and colonial controls at the ethnicity-level include the level of precolonial centralization and log total exports of slaves from the region during the Atlantic slave trade. ${ }^{* *}$ Significant at the 1 percent level, ${ }^{* *}$ Significant at the 5 percent level, ${ }^{*}$ Significant at the 10 percent level. 